GEOLOGICAL SURVEY CIRCULAR 750

\title{
Geological Studies on the COST No. B-2 Well, U.S. Mid-Atlantic Outer Continental Shelf Area
}




\section{Geological Studies on the COST No. B-2 Well, U.S. Mid-Atlantic Outer Continental Shelf Area}

P. A. Scholle, Editor

GEOLOGICAL SURVEY CIRCULAR 750 
United States Department of the Interior CECIL D. ANDRUS, Secretary

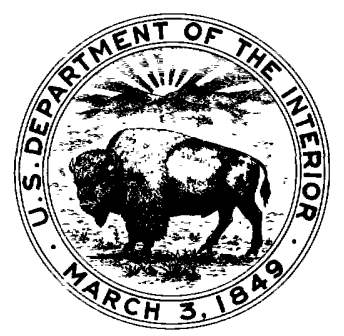

\section{Geological Survey}

V. E. McKelvey, Director

Library of Congress catalog-card No. 77-72294 


\section{CONTENTS}

Abstract

Introduction

Acknowledgments

Geologic setting, by R. E. Mattick -.-_-_-_--

Data summary and petroleum potential, by

P. A. Scholle

Lithologic descriptions, by E. C. Rhodehamel --

Techniques

Sand, shale, and carbonate content

Sandstone porosities, by E. C. Rhodehamel -.--

Sandstone petrography, by P. A. Scholle -...--

Composition

Diagenesis and cementation

Conclusions

Foraminiferal biostratigraphy, by C. W. Poag --

Pleistocene

Pliocene

Miocene

Eocene -...-...-

Paleocene -.-..-_-

Cretaceous

Paleoecology

Nannofossil biostratigraphy, by P. C. Valentine-

Pleistocene through Miocene

Oligocene

Oligocene through Eocene

\begin{tabular}{|c|c|}
\hline age & \\
\hline 1 & Nanofossil biostratigraphy-Continued \\
\hline 1 & 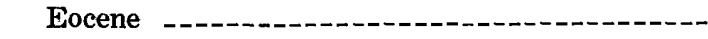 \\
\hline 3 & Eocene through Paleocene \\
\hline 4 & 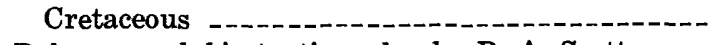 \\
\hline 8 & $\begin{array}{l}\text { Palynomorph biostratigraphy, by R. A. Scott } \\
\text { and E. I. Robbins }\end{array}$ \\
\hline 15 & Results \\
\hline 15 & Paleoecology \\
\hline 15 & 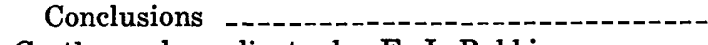 \\
\hline 23 & Geothermal gradients, by E. I. Robbins \\
\hline 32 & Organic geochemistry, by G. E. Claypool, C. M. \\
\hline 32 & Lubeck, J. P. Baysinger, and T. G. Ging \\
\hline 32 & Results and conclusions \\
\hline 34 & Geochemical measurement and interpretation \\
\hline 35 & \\
\hline 35 & Color alteration of visible organic matter, by \\
\hline 35 & E. I. Robbins - \\
\hline 35 & Data - - - \\
\hline 36 & Conclusions \\
\hline 36 & Geophysical studies, by D. J. Taylor, R. E. \\
\hline 36 & K. C. Bayer - \\
\hline 36 & Seismic stratigraphy \\
\hline 37 & Lithologic information \\
\hline 37 & Amplitude anomalies \\
\hline 37 & 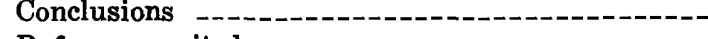 \\
\hline 37 & ait \\
\hline
\end{tabular}

\section{ILLUSTRATIONS}

FIGURE 1. Locality map

2. Generalized cross section of Atlantic Continental Shelf, Slope, and Rise

3. Interpretive profile of part of USGS Line 2 .

4. Generalized lithology and depositional environments.--

5. Comparison of $\log$ and core porosity-permeability data

6. Comparison of various measures of thermal maturity as a function of depth -

7. Sand, shale, and carbonate content as a function of depth -

8. Density and sonic-log porosity as a function of depth

9. Geothermal gradient for COST No. B-2 well -

10. Temperature of maximum pyrolysis yield as a function of depth

11. Calibration of temperature of maximum pyrolysis yield with respect to coal rank ----------

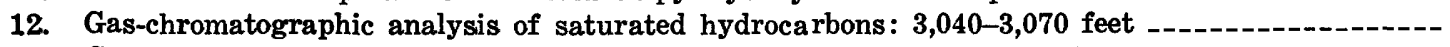

13. Gas-chromatographic analysis of saturated hydrocarbons: $3,580-3,610$ feet

14. Gas-chromatographic analysis of saturated hydrocarbons: 11,260-11,290 feet --.---.---.---

15. Gas-chromatographic analysis of saturated hydrocarbons: $12,160-12,190$ feet ---.---.---.---

16. Gas-chromatographic analysis of saturated hydrocarbons: $15,900-16,030$ feet

17. Summary and comparison of analyses of richness of sediments in the COST No. B-2 well -.-.=

18. Summary and comparison of analyses of type of organic matter in COST No. B-2 well samples

19. Summary and comparison of analyses of maturity of organic matter in the COST No. B-2 well --

20. Maturation, abundance, and types of sapropel, abundance of organic matter, and weight percent organic carbon as a function of depth

21. Seismic travel time (two-way) as a function of depth from the COST No. B-2 well sonic logs --

22. A computer model of possible lithologies and physical parameters determined from amplitude anomaly or "bright spot" on seismic-reflection profile (fig. 3) between shotpoints 630 and 750 -- 


\section{TABLES}

TABLE 1. Comparison of biostratigraphic analyses from the COST No. B-2 weli

2. Sedimentation rates of stratigraphic units of Berriasian to Pleistocene age in the COST No. B-2 well

3. Depositional environments determined from lithologic associations in COST No. B-2 well sediments

4. Lithologic $\log$ of the COST No. B-2 well

5. Sand, shale, and carbonate content in the COST No. B-2 well

6. Comparison of porosity $(\phi)$ values determined from electric $\log$ and core measurements on COST No. B-2 well samples

7. Petrography of sandstone from the COST No. B-2 well

8. Preliminary age determinations of COST No. B-2 samples on the basis of calcareous nannofossils

9. Circum-Atlantic off shore geothermal gradients

10. Organic content of sediments from the COST No. B-2 well, obtained by combustion and thermal-analysis/pyrolysis

11. Summary of chloroform extraction yields, column chromatographic separation of $\mathrm{C}_{15+}$ hydrocarbon fractions, and estimate of carbon preference index (CPI) by gas chromatography from

12. COST No. B-2 well samples

$\mathrm{C}_{1}-\mathrm{C}_{7}$ hydrocarbon analyses of selected samples from the COST No. B-2 well 


\title{
Geological Studies on the COST No. B-2 Well, United States Mid-Atlantic Outer Continental Shelf area
}

\author{
P. A. Scholle, Editor
}

\begin{abstract}
The COST No. B-2 well is the first deep stratigraphic test to be drilled on the United States Atlantic Outer Continental Shelf (AOCS) area. The well was drilled on the eastern flank of the Baltimore Canyon trough to a total depth of 16,043 feet; it penetrated a section composed almost entirely of sand and shale with subordinate amounts of limestone, coal, and lignite. Biostratigraphic studies have shown that the uppermost 5,000 feet is of Tertiary and Quaternary age and was deposited in nonmarine to deep marine environments. The Upper Cretaceous section is about 3,000 feet thick and is of dominantly shallow marine origin. The basal 8,000 feet of sediment has been tentatively determined to be entirely of Early Cretaceous age, the basal sediments being dated as Berriasian. This Lower Cretaceous section is primarily nonmarine to very shallow marine in origin.

Examination of cores, well cuttings, and electric logs shows that thick potential reservoir sands are found through much of the section. However, porosity and permeability decrease strikingly in the deeper parts of the Lower Cretaceous section as a result of compaction and cementation. Most of the sands are quite feldspathic, and progressive decomposition of feldspar stimulates authigenic clay and silica formation.

Studies of color alteration of visible organic matter, organic geochemistry, and vitrinite reflectance show that although many units have high organic-carbon contents, moderately low geothermal gradients may have retarded thermal maturation. This, in conjunction with the scarcity of marine-derived organic matter in the lower part of the section, suggests a relatively low potential for the generation of liquid hydrocarbons. However, the overall combination of source beds, reservoirs, seals, structures, and thermal gradients may be favorable for the generation and entrapment of natural gas. Furthermore, the presence of reservoir rocks, seals, and trapping structures may indicate a significant potential for entrapment of either natural gas or petroleum that was generated deeper in the basin and then migrated either laterally or vertically.
\end{abstract}

\section{INTRODUCTION}

Until recently, all information on the strati. grap'ic framework of the United States At- lantic Outer Continental Shelf (AOCS) had come from onshore wells, offshore bottom sampling or shallow coring, geophysical surveys, and extrapolation from Canadian offshore wells. Between December 14, 1975, and March 28, 1976, however, the first deep stratigraphic test well was drilled on the U.S. AOCS by Ocean Production Company acting as operator for a group of 31 petroleum companies, the Continental Offshore Stratigraphic Test (COST) Group. This hole, designated the COST NO. B-2 well, was drilled on the outer part of the AOCS about 91 miles east of Atlantic City, N.J., at lat $39^{\circ} 22^{\prime} 31.972^{\prime \prime}$ N. and long $72^{\circ} 44^{\prime} 03.871^{\prime \prime} \mathrm{W}$. (fig. 1). The well was drilled using the semisubmersible rig SEDCO-J. Water depth at the site is 298 feet, and drilling continued to a depth of 16,043 feet below the Kelly Bushing (or to 15,953 feet below sea level). The well is adjasent to the area offered for leasing on Aug. 17, 1976, as part of Lease Sale No. 40, shown on figure 1. The granting of federal leases within 50 miles of the drill site on Sept. 1, 197.6, has made possible the publication of detailed information $a$ 'out the geolog:cal findings from the COST No. B-2 well, because Lease Stipulation No. 4 provides for public disclosure by the U.S. Geological Survey (USGS) of all geological information on the well 60 days after such leasing.

Considerable basic lithologic and stratigraphic data, most of it derived from industry reports, has been released (Smith and others, 1976). This circular summarizes some of that data and adds information from other USGS studies. It is by no means an exhaustive or completed program, but because the COST No. B-2 well has such immediate interest for both 


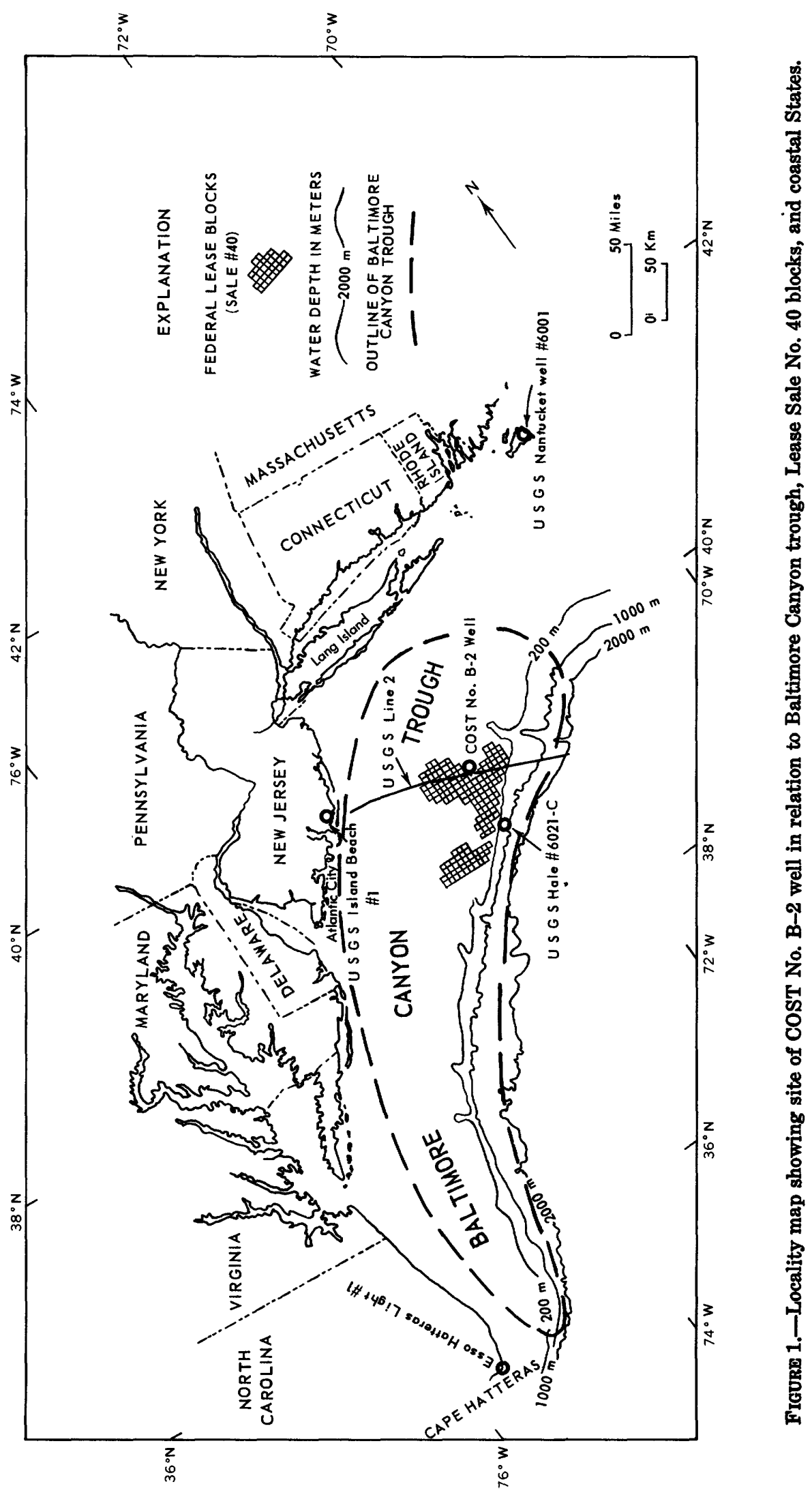


the petroleum industry and academic workers, we believe that publication of preliminary results is justified.

The publication is divided into separately authored sections on geological, geochemical, and geophysical topics. Environmental or operational details are not included, as these have been amply described by Smith and others (1976). Several diagrams are provided in the section, "Data Summary and Petroleum Potential," to compare the analytical results of USGS work with the industrial data summarized by Smith and others (1976).

All work reported on in this paper has been done using rotary drill cutting rather than conventional or sidewall cores. Electric logs and core descriptions were available, however, to aid in checking the accuracy of sample depth assignments. The cuttings, in conjunction with electric $\log s$, thus provided a useful picture of the complete spectrum of lithologic variation within a given interval and were sometimes more useful than the spot samples provided by sidewall coring. All depth references in this report for electric log, core, or cuttings data are based on depth below the Kelly Bushing (K.B.) which is 90 feet above mean sea level and 388 feet above the sediment-water interface.

\section{ACKNOWLEDGMENTS}

Technical assistance in the preparation of this report is gratefully acknowledged from the following USGS personnel: Norman $O$. Fredriksen for examining Tertiary pollen, Fred E. May for examining dinoflagellates, and Robert $\mathrm{H}$. Tschudy for examining megaspores. Zoe Ann Hamlin, Peter Stinger, Lois Tomlinson, and Sandra Wortman helped greatly in sample preparation and analysis. Early versions of this paper were reviewed by Richard Q. Foote, Oswald W. Girard, Jr., Raymond Christopher, Harlan R. Bergquist, and Robert E. Miller. We are indebted to them for their many helpful suggestions. 


\section{Geologic Setting}

By R. E. Mattick

The COST No. B-2 well is near the axis of the Baltimore Canyon trough, an elongate, northeast-trending structural depression in continental basement rocks filled with more than 40,000 feet of sediment (fig. 1). The trough, a possible offshore extension of the Salisbury embayment, extends from about Long Island, N.Y., southwestward to the vicinity of Cape Hatteras, N.C. A diagrammatic cross section of the Baltimore Canyon trough is shown in figure 2. This seaward-thickening sedimentary wedge is built over a deeply buried fault zone which may represent a transition between continental and oceanic basement rocks. A seismic profile (fig. 3) shows that Jurassic and Cretaceous sedimentary rocks, which are gently dipping throughout most of the Baltimore Canyon trough area, are warped upward by a large basement intrusion on the Continental Shelf off New Jersey.

On the basis of magnetic and gravity data, early authors proposed that a volcanic or basement ridge, which may have acted as a sediment dam during Jurassic and Early Cretaceous time, is buried about 15,000 feet beneath the outer shelf and slope (Drake and others, 1959). Later, Mattick and others (1974) suggested that the main part of the Batlimore Canyon trough, the part underlying the midshelf area, is a broad graben to which is coupled a large horst, buried at a depth of about 25,000 feet beneath the shelf edge. Whether or not crystalline rocks or highvelocity sedimentary rocks are present deeper than about 20,000 feet at the shelf edge has not been determined from available seismic data. Schlee and others (1976) have speculated that the rocks are sedimentary and that the shelf edge is underlain by a deeply buried carbonate platform with reef deposits that formed atop a block-faulted margin after separation of the African and North American plates.

By analogy with the Coastal Plain, the basement beneath the Baltimore Canyon trough area is inferred to consist of Paleozoic and Precambrian(?) metamorphic rocks similar to those exposed in the Applachian Piedmont province (Perry and others, 1975). Downfaulted grabens in the basement probably are present locally and may be filled with Triassic rocks consisting of nonmarine arkosic sandstones, shales, basaltic lava flows, and diabase intrusions. Seismic evidence indicates that as much as 45,000 feet of sediments unconformably overlies the Triassic and pre-Triassic basement rocks (Mattick and others, 1975).

The basal part of the sedimentary section may contain Paleozoic and marine Triassic sediments. Seismic velocities of sedimentary rocks deeper than about 25,000 feet are in excess of 20,000 feet/sec.; these high velocities may indicate a thick section of chiefly Jurassic carbonate rocks underlain by evaporites (Mattick and others, 1976). By analogy with well data from the Scotian Shelf (McIver, 1972), we infer that these carbonate rocks are overlain by several thousand feet of Jurassic sands and shales.

According to Minard and others (1974), Lower Cretaceous sediments constitute a major deltaic sequence in the emerged Coastal Plain. The results from the COST No. B-2 well, which penetrated approximately 8,000 feet of Lower Cretaceous rocks that have a high percentage of massive sandstone, indicate that these deltaic sediments extend seaward across much of the Continental Shelf. However, on the basis of seismic-reflection velocities, Mattick and others (1975) believe that basal Lower Cretaceous rocks at the shelf edge are chiefly carbonate rocks. 


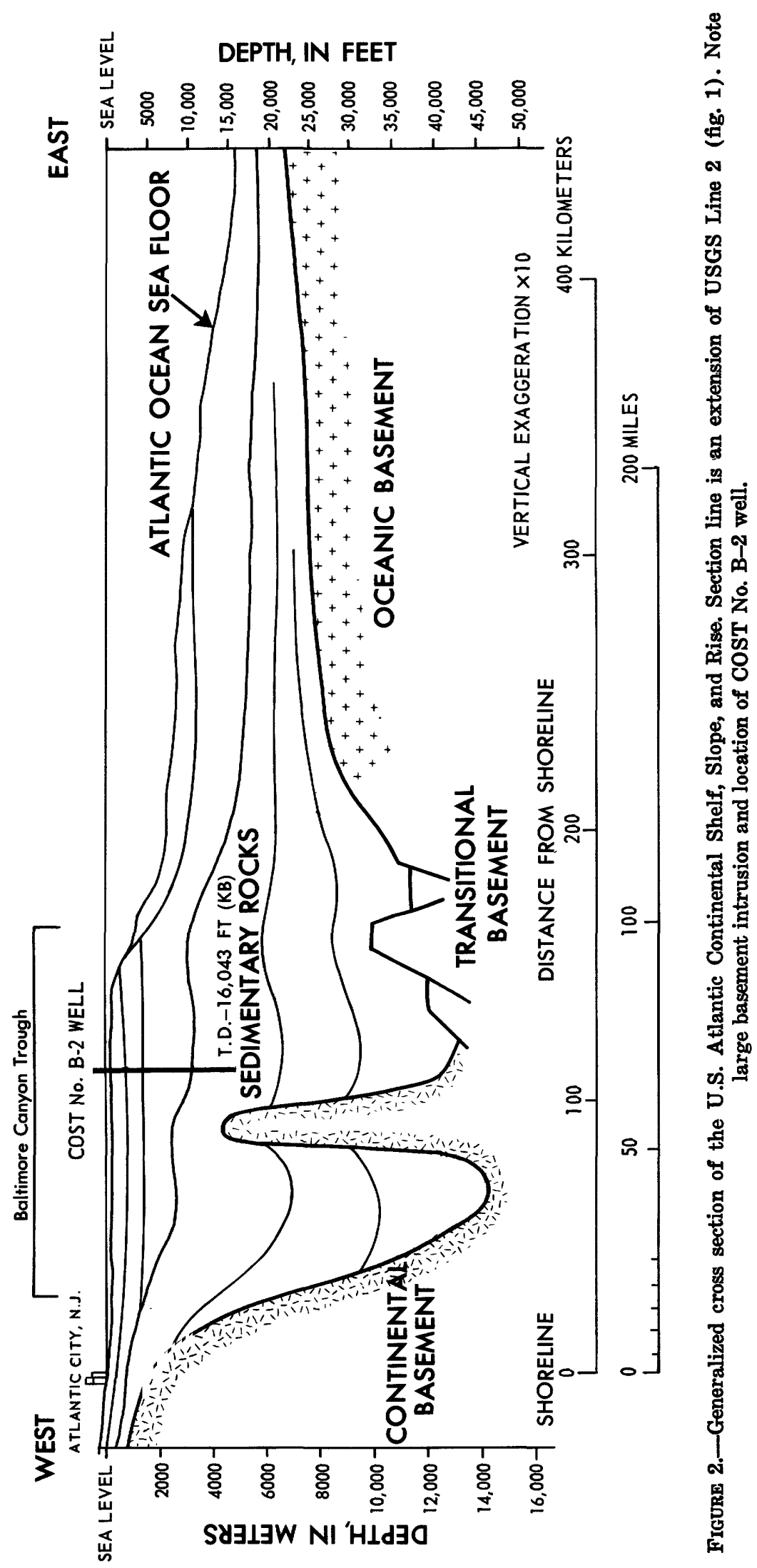




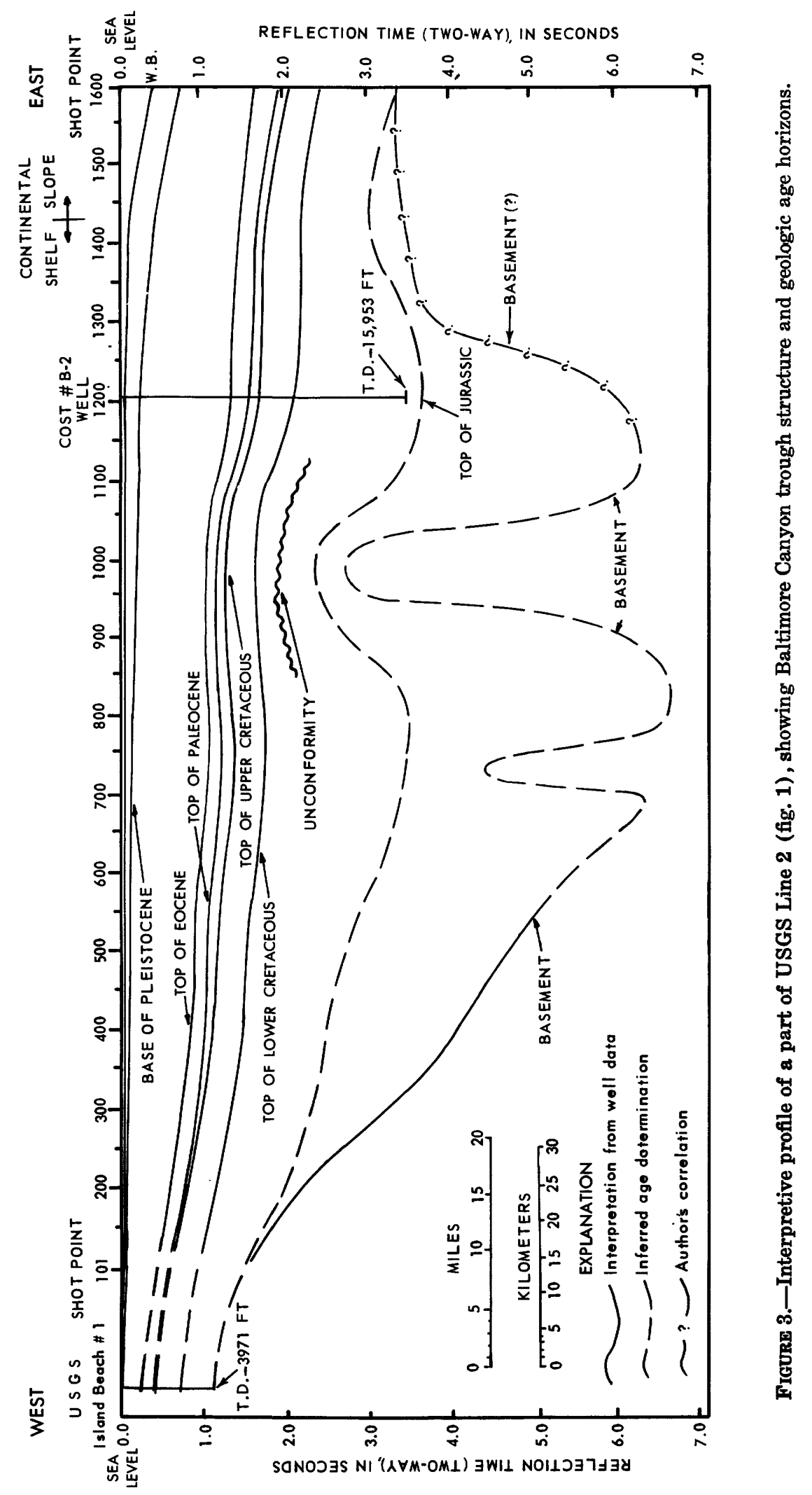


At the B-2 site, the Upper Cretaceous section is approximately 3,000 feet thick, and the Tertiary section is about 5,000 feet thick. On the basis of seismic correlation, these thicknesses appear to remain relatively constant over most of the AOCS area.

Some of the highest bonus bids of Lease Sale No. 40 involved lease blocks over a basement intrusion in the central Baltimore Canyon trough area (West, 1976). Figure 3 is a schematic diagram of a seismic-reflection record that crosses this feature. Jurassic(?) and Lower Cretaceous beds appear to have been arched several thousands of feet across an area approximately 15 miles wide. A seismic horizon slightly below the Lower Cretaceous-Upper Cretaceous boundary represents a marked unconformity at which at least 1,300 feet of sediment was removed by erosion.
The unconformity just below the Lower Cretaceous-Upper Cretaceous boundary probably dates the last major upward movement of the intrusive body. However, arching, thinning, and minor faulting of Upper Cretaceous beds, and slight thinning of lower Tertiary beds above the intrusive body could reflect later movement.

Other Cretaceous tectonic activity may be illustrated by growth faults along the shelfslope break (Mattick and others, 1974). Emery and others (1970) reported that diapiric salt structures may be present along the Continental Slope and Rise off Nova Scotia. Sheridan (1974) extended this province southward and reported the possibility of salt diapirism in the Baltimore Canyon trough area. 


\title{
Data Summary and Petroleum Potential
}

\author{
By P. A. Scholle
}

The COST No. B-2 well penetrated 15,655 feet of Mesozoic and Cenozoic section. Lithologic and paleoenvironmental studies, summarized in figure 4, indicate that the upper 2,000 feet of section has very sandy shallow marine to nonmarine deposits. Below that, to a total drilling depth of about 6,000 feet, a deeper water, finer grained section is present. From that level to the base of the well, the section consists of alternating sandstones and shales of shallow marine to nonmarine origin. This deeper part of the section contains many coal and lignite seams.

Biostratigraphic work completed to date (and summarized in table 1) shows general agreement between the various workers on most stage and series boundaries. The Cretaceous-Tertiary boundary is placed between 5,000 and 5,600 feet by different workers, and the Lower Cretaceous-Upper Cretaceous boundary is very close to the 8,200 -foot level. Although the basal part of the section might well be Jurassic, the consensus now favors a Berriasian (Early Cretaceous) age for these sediments.

The rates of sedimentation of various stratigraphic units in the B-2 area were quite variable, as shown in table 2. For discussion purposes, the Miocene to Pleistocene rates have been taken as average; relative to these, the entire interval from Campanian to Oligocene had low rates of sedimentation. This corresponds generally with the time interval of deepest water sedimentation in this area. Albian to Santonian time was characterized by shallower water deposition and generally average sedimentation rates; Berriasian to Aptian time was marked by very shallow marine to nonmarine deposition and average to very high rates of sedimentation.

A major part of the Cretaceous section (that is, the section between 5,000 and 16,000 feet) consists of relatively thick sandstone units, some of which have significant reservoir potential. The reservoir quality of this sandstone, however, deteriorates consistently as depth increases. The relationship between depth and petrophysical characteristics determined from electric logs as well as from cores is shown in figure 5. The porosity loss below 12,000 feet is largely related to compaction effects and to progressive breakdown of feldspar accompanied by growth of authigenic clay and silica cement. Generation of calcite cement is also important, especially in zones that contain marine fossils or limestone. As seen on figure 5, these porosity losses, especially, the formation of authigenic clay, have a drastic effect on permeability. Thus, in the section below 12,000 feet few sandstones have more than 1 millidarcy (md) permeability.

Geochemical studies of the COST No. B-2 well have shown that the area not only has a relatively low geothermal gradient today but that apparently it has been that low or even lower throughout the Cretaceous to Holocene history. Data from color alteration of visible organic matter, pyrolytic-decomposition temperatures, carbon-preference index, and vitrinite reflectance are summarized in figure 6 .

All methods indicate that the section down to at least 8,000 feet is thermally immature and is unlikely to have yielded hydrocarbons other than biogenically generated methane. Below 8,000 feet there is some disagreement in interpretation between the various analytical techniques. The techniques based on observations of visible organic matter indicate moderate to full thermal maturity in the 8,000- to 16,000-foot depth range. For example, vitrinitereflectance values of 0.45 to 0.50 , found at about 8,000 feet in the COST No. B-2 well, are generally taken as marking the earliest onset of possible liquid-hydrocarbon generation (Bar- 


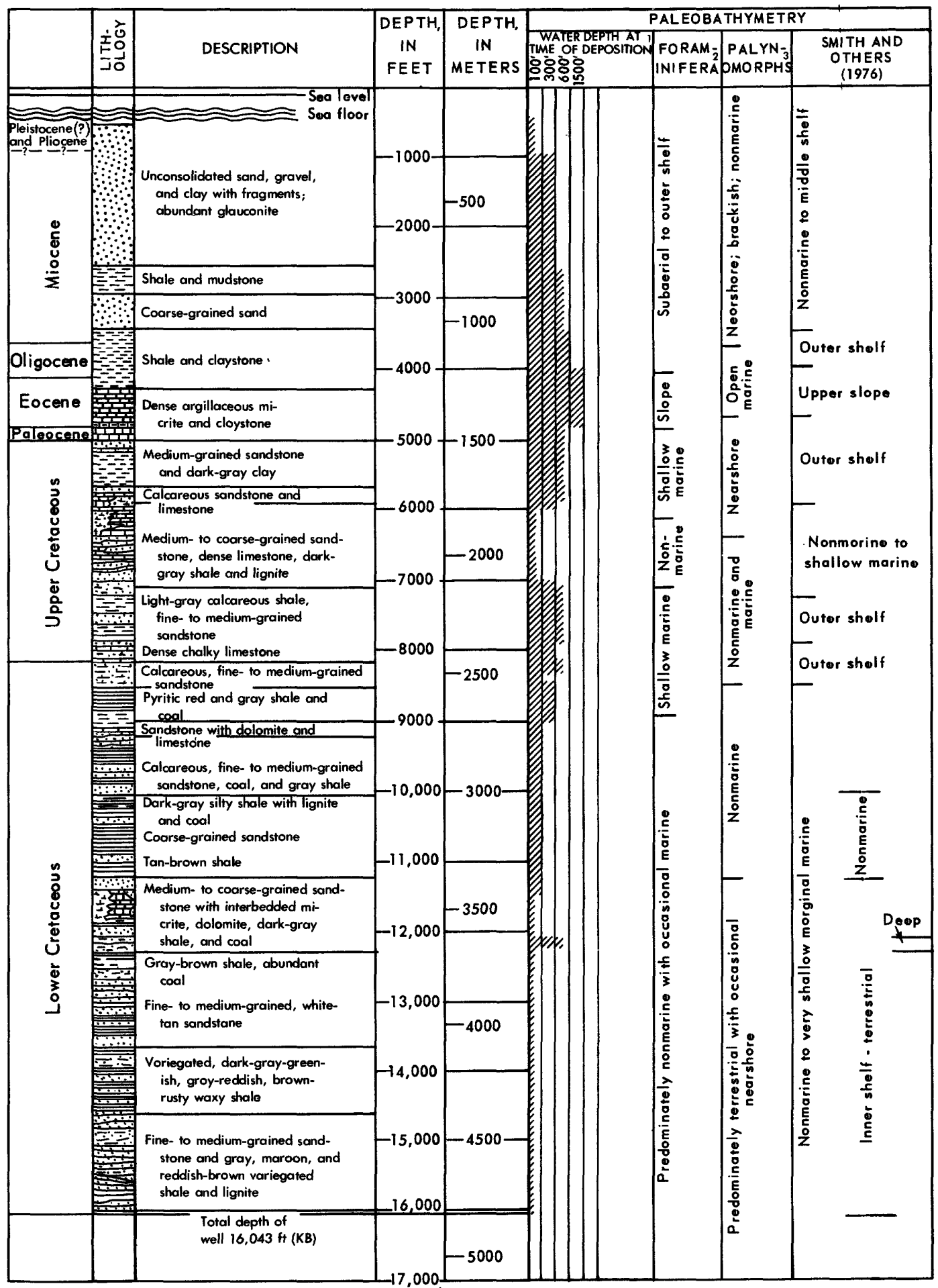

1 Consensus of Smith and others (1976), Poog (this volume), and

Valentine (this volume).

2 Poog (this volume)

${ }^{3}$ Valentine (this volume).

FIGURE 4.-Generalized plot of lithologies and depositional environments of sediments in the COST No. B-2 well. Modified from Smith and others (1976). 
TABLE 1.-Comparison of biostratigraphic analyses from the COST No. B-2 well

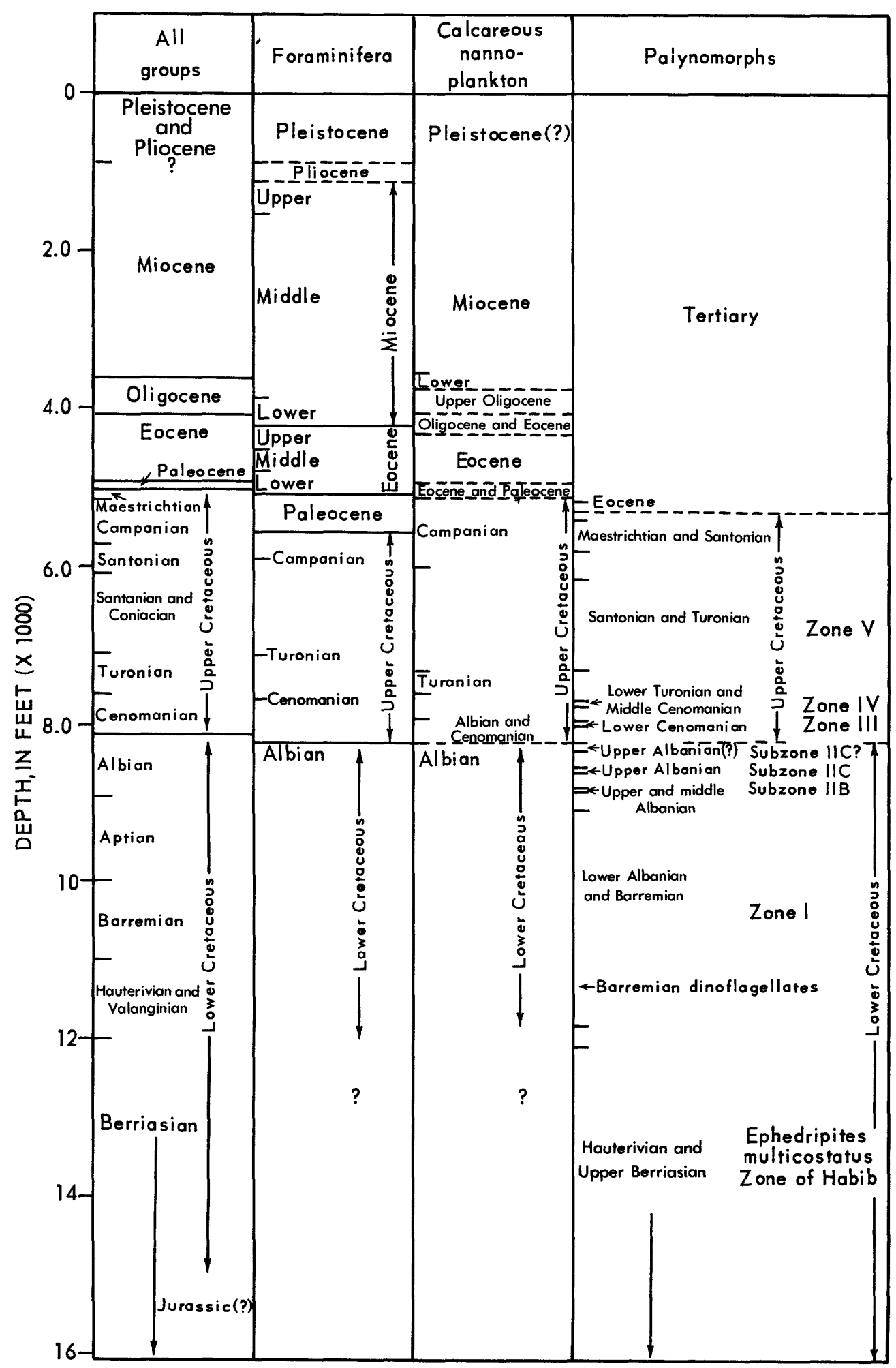


TABLE 2.-Sedimentation rates of stratigraphic units of Berriasian to Pleistocene age in the COST No. B-2 well

\begin{tabular}{|c|c|c|c|c|c|c|}
\hline Unit & $\begin{array}{c}\text { Sedi- } \\
\text { ment } \\
\text { thick- } \\
\text { ness } \\
(\mathrm{ft})\end{array}$ & $\begin{array}{c}\text { Dura- } \\
\text { tion } \\
\text { (mil- } \\
\text { lions } \\
\text { of } \\
\text { years) } 1\end{array}$ & $\begin{array}{c}\text { Per- } \\
\text { cent } \\
\text { of } \\
\text { total } \\
\text { sedi- } \\
\text { ment }\end{array}$ & $\begin{array}{l}\text { Per- } \\
\text { cent } \\
\text { of } \\
\text { total } \\
\text { time } 1\end{array}$ & $\begin{array}{l}\text { Rela- } \\
\text { tive } \\
\text { sedi- } \\
\text { ment- } \\
\text { ation } \\
\text { rate }\end{array}$ & $\begin{array}{c}\text { Abso- } \\
\text { lute } \\
\text { sedi- } \\
\text { ment- } \\
\text { ation } \\
\text { rate } \\
\text { (ft } / \mathrm{m} . \mathrm{y} .)\end{array}$ \\
\hline $\begin{array}{l}\text { Pleistocene and Pliocene } \\
\text { Miocene } \\
\text { Oligocene } \\
\text { Eocene } \\
\text { Paleocene } \\
\text { Maestrichtian and Campanian } \\
\text { Santonian and Coniacian } \\
\text { Turonian } \\
\text { Cenomanian } \\
\text { Albian } \\
\text { Aptian } \\
\text { Barremian, Hauterivian and Valanginian } \\
\text { Berriasian } \\
\quad \text { Total }\end{array}$ & $\begin{array}{r}522 \\
2,686 \\
486 \\
882 \\
36 \\
736 \\
1,321 \\
553 \\
520 \\
770 \\
1,100 \\
2,000 \\
4,042 \\
15,654\end{array}$ & $\begin{array}{r}5 \\
18 \\
15 \\
14 \\
11 \\
13 \\
8 \\
6 \\
8 \\
8 \\
7 \\
16 \\
4 \\
133\end{array}$ & $\begin{array}{r}3 \\
17 \\
3 \\
5 \\
<1 \\
5 \\
8 \\
3 \\
3 \\
5 \\
7 \\
12 \\
25\end{array}$ & $\begin{array}{r}4 \\
13 \\
11 \\
10 \\
8 \\
10 \\
6 \\
4 \\
6 \\
6 \\
5 \\
12 \\
3\end{array}$ & $\begin{array}{l}\text { Average } \\
\text { Average } \\
\text { Low } \\
\text { Low } \\
\text { Very low } \\
\text { Low } \\
\text { High } \\
\text { Average } \\
\text { Low } \\
\text { Average } \\
\text { High } \\
\text { Average } \\
\text { Very high }\end{array}$ & $\begin{array}{r}104 \\
149 \\
32 \\
63 \\
3 \\
56 \\
165 \\
92 \\
65 \\
96 \\
157 \\
125 \\
1,011\end{array}$ \\
\hline
\end{tabular}

1 From Berggren (1972) and Van Hinte (1976).

tenstein and Teichmüller, 1974; Hood and others, 1975; Vassyoevich and others, 1970). Likewise, vitrinite-reflectance values of 0.6 to 0.7, and sapropel-maturation values of 2.5 to 3.0 found below 12,000 feet in the COST No. B-2 well, mark the peak rate of liquid-hydrocarbon formation. Thus, on the basis of such data, the present temperature profile in the well, and provided that sediments containing suitable organic matter are present, significant liquid hydrocarbons should have been generated.

Geochemical analyses of disseminated organic matter yield a different picture, however. Studies of extractable organic matter presented by Claypool and others (this volume), Geochem Laboratories (1976), and Smith and others (1976) have indicated that none of the sediments penetrated in the COST No. B-2 well are mature with respect to liquid-hydrocarbon generation. Indications are that minor amounts of liquid and significant amounts of gaseous hydrocarbons may have been generated, but large amounts of liquid-petroleum hydrocarbons have not yet been generated.

These differences in apparent maturity found by means of visual and geochemical techniques are not easily explained. Considerable disagreement still exists about the exact time-temperature relations needed for oil formation and the effect of type of organic matter and other factors upon rates of formation (for example, Tissot and others, 1974). Thus, the noted discrepancies may be due to incorrect extrapola- tion of maturity versus oil-generation values from other basins. Indeed, recent workers have tended to place the main phase of oil generation at greater and greater depths and temperatures (for example, Hood and Castaño, 1974). On the basis of such work there is little discrepancy between visual and geochemical analyses; both would indicate only marginal maturity with respect to liquid-petroleum-hydrocarbon generation at the base of the COST No. B-2 well.

The type as well as the amount of organic matter present in the sediments plays a major role in the determination of the hydrocarbon potential of the section. In the COST No. B-2 well, some of the highest organic carbon contents (as much as 12 percent) are present between 3,000 and 6,000 feet and 9,500 and 14,000 feet. The lower of these two intervals has a very significant amount of coal, especially between 9,500 and 11,300 feet and 12,400 and 14,000 feet. The dominance of terrestrial over marine-derived organic matter in this interval strongly reduces the probability of generation of economic amounts of liquid-petroleum hydrocarbons but allows a high potential for generation of wet or dry gas. Furthermore, significant potential exists for lateral or vertical migration of liẹuid or gaseous hydrocarbons from structurally or stratigraphically deeper parts of the section.

Some supporting evidence for the presence of natural-gas deposits may come from Hole No. 6021-C of the USGS Atlantic Margin Coring Project (fig. 1), which was drilled at lat $38^{\circ} 57.92^{\prime}$ N., long $72^{\circ} 49.20^{\prime}$ W. The upper 


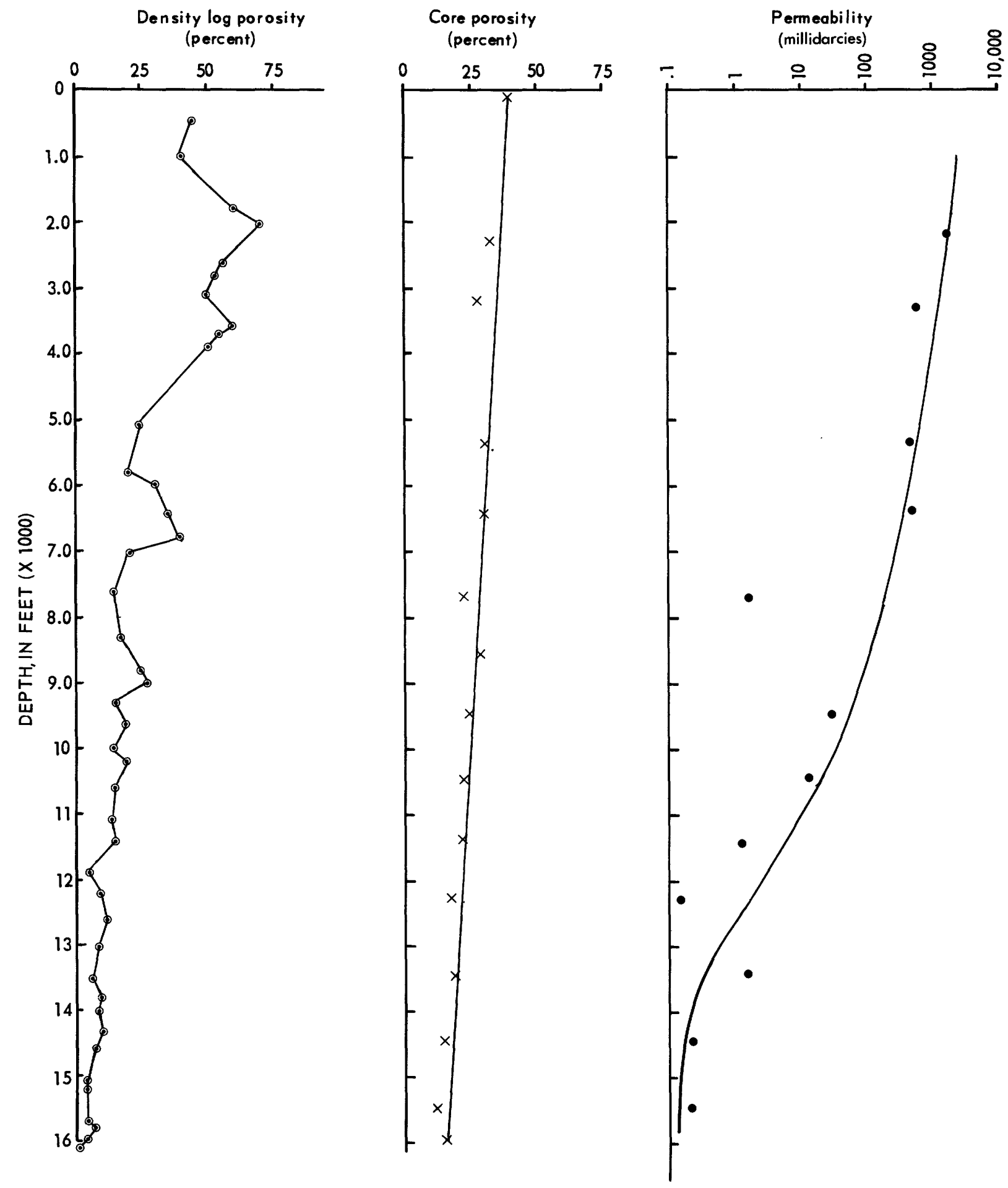

FIGURE 5.-Comparison of density log curve of porosity (from Rhodehamel, this volume) with measured core porosities and empirically determined permeabilities from Core Laboratories as given by Smith and others (1976).

1,000 feet of sediment was penetrated at this site and contained significant amounts of the light hydrocarbons (methane, ethane, and propane). Although R. E. Miller and D. M. Schultz (written commun., 1976) believe that

the methane is dominantly biogenic in origin, some leakage from deeper natural-gas sources may exist. Several samples of gas-bearing mud from this borehole have been analyzed for stable carbon-isotopic composition of the 


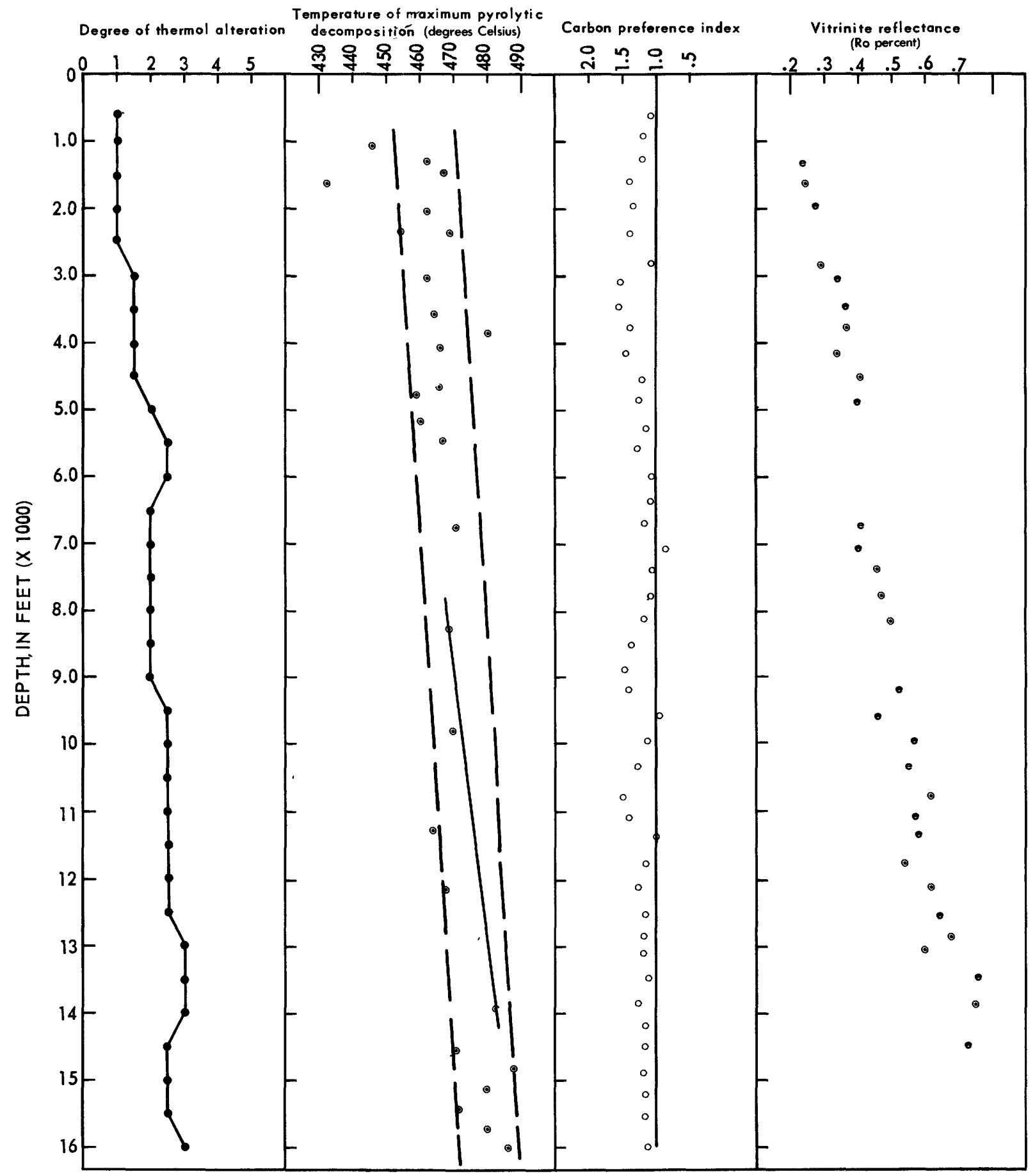

FIGURE 6.-Comparison of various measures of thermal maturity as a function of depth in COST No. B-2 well. Degree of thermal alteration is from Robbins (this volume); pyrolitic decomposition data are from Claypool and others (this volume); carbon-preference index and vitrinite-reflectance data are from Geochem Laboratories and Superior Oil Co., respectively, as reported in Smith and others (1976).

methane. These preliminary results $\left(\delta^{13} \mathrm{C}_{\mathrm{PDB}} \cong\right.$ -35 to -45 per mil) may indicate seepage from deeper parts of the section. However, because of the extremely small quantities of gas obtained and analyzed, the results should not be interpreted as unequivocal support for a thermogenic origin of the methane (G. E. Claypool, written commun., 1976).

Further indication of possible gas deposits comes from bright-spot analysis of USGS Line 
2 (discussed in the section on Geophysical studies). A major amplitude anomaly, a considerable distance landward of the COST No. B-2 well site, has been tentatively interpreted as a natural-gas deposit.

Essentially five major factors are involved in the origin and entrapment of hydrocarbons: (1) source rocks, (2) temperatures sufficient to generate gas or oil, (3) reservoir rocks, (4) seals, and (5) trapping structures. Indications from the B-2 well are that rocks of high organic-carbon content are present from 3,000 to 6,000 feet and 9,000 to 14,000 feet and that some of these rocks are capable of generating considerable amounts of hydrocarbons. Temperatures may have been too low in much of this section to have generated liquid hydrocarbons, but they appear to have been sufficient for gas generation. Reservoir rocks are abundant throughout most of the COST No. B-2 well section, although the reservoir quality of most of the sandstone units degrades rapidly at depths greater than 10,000 to 12,000 feet. Seals, in the form of shale, are present in much of the section. Finally, as shown in the section "geologic setting," large structures are available for hydrocarbon entrapment in areas adjacent to the COST No. B-2 well. These structures may also enhance vertical migration of hydrocarbons along fractures from deeper parts of the section.

Data from the COST No. B-2 well indicate a higher potential for natural gas than for liquid petroleum. Moving in the direction of a more marine section would give a higher potential for oil generation, lower feldspar content (and thus less cementation at depth), and more shale seals. Likewise, moving to possible areas of higher paleogeothermal gradients would improve the potential for either oil or gas generation. 


\section{Lithologic Descriptions}

By E. C. Rhodehamel

The COST No. B-2 well penetrated sediments deposited in environments ranging from nonmarine to deep water (table 3) and ranging in age from Holocene to earliest Early Cretaceous; basement rock was not penetrated. Although significant amounts of carbonate sediments are present in the lower Tertiary and Upper Cretaceous intervals, sandstone and shale predominate. The detailed lithologic log (table 4) includes tentative stratigraphic intervals provided by other investigators (Smith and others, 1976).

\section{TECHNIQUES}

Well cuttings (samples) were collected at 30foot intervals between 610 and 4,620 feet and at 10-foot intervals between 4,620 and 16,043 feet. In this preliminary study, samples were analyzed at sampling intervals of 90 feet down to 4,620 feet, and intervals of 30 feet below that depth. Intervening samples were examined where initial sample volume was adequate. In addition to the well cuttings, four conventional cores were examined. These cores were taken at 5,030 to 5,090 feet with 1.5 feet of recovery; at 8,238 to 8,268 feet, with 28.4 feet of recovery; at 9,280 to 9,330 feet with complete recovery; and at 13,420 and 13,471 feet with 34.5 feet of recovery. More than 800 sidewall cores were taken; these cores were not directly examined in this study, but the core descriptions (Core Laboratories, 1976) were checked against lithologic picks from cuttings and logs.

Because of variations in drilling rate, mud circulation time, mudcake failures, hole washouts, and other operational factors, the lithologic samples for specified intervals often do not adequately represent the actual material penetrated; contamination and mixing from above are also factors. Furthermore, the samples were washed so that the natural muds and fines were lost while the drilling mud was being removed. Accordingly, it was necessary to rely heavily upon the various geophysical logs. The logs used most frequently were the spontaneous-potential (SP) and dual-induction logs (DIL), the formation-density compensated log (FDC), the simultaneous compensated neutron and formation-density logs (CNL-FDC), the natural gamma-ray log (GR), the borehole compensated sonic log (BHC), and the caliper $\log$. These logs, along with the available washed well-cutting samples were the primary data sources for the assembly of the lithologic log presented below. The observations from 300 to 610 feet were made entirely from the gammaray $\log$.

Summary lithologic descriptions have been provided by Smith and others (1976). The lithologic log presented here is a bed-by-bed description (unit lithologic description) of significant sedimentary layers. The general lithology is presented with only enough detail to indicate the rock type and some general qualifiers. The described lithology when assessed in its overall sediment context appears to provide rough but reasonable inferences as to the gross environments of deposition, especially when these assessments are combined with analyses of sedimentary structures from core slabs. These depositional environments are tentatively listed in table 3 , and the lithologic log is given in table 4.

Zones of high radioactivity are found at $8,399,8,655,9,315,9,585,9,990,12,223,12,276$, 13,292, and 13,331 feet. These horizons often contain phosphatic pebbles and glauconite and may represent hiatus surfaces.

\section{SAND, SHALE, AND CARBONATE CONTENT}

Compilation of the lithologic log provides a means of evaluating depth-related variations in the relative percentages of common rock types such as sandstone, shale (including siltstone 
TABLE 3.-Depositional environments determined from lithologic associations in COST No. B-2 well sediments [?, uncertain determination]

\begin{tabular}{|c|c|c|c|c|c|c|c|c|}
\hline & \multirow{5}{*}{$\begin{array}{l}\text { Approximate } \\
\text { depth } \\
\text { (feet) }\end{array}$} & \multicolumn{7}{|c|}{ Depositional environment } \\
\hline & & \multicolumn{2}{|c|}{ NONMARINE } & \multicolumn{5}{|c|}{ MARINE } \\
\hline & & \multirow{3}{*}{$\begin{array}{l}\text { Terrestrial } \\
\text { (fluvial, } \\
\text { glacial, } \\
\text { aeolian) }\end{array}$} & \multirow{3}{*}{$\begin{array}{c}\text { Transi- } \\
\text { tional, } \\
\text { (lagoonal, } \\
\text { estuarine, } \\
\text { tidalal } \\
\text { inlet) }\end{array}$} & \multirow{3}{*}{$\begin{array}{c}\text { Nearshore } \\
\text { (beach, } \\
\text { bar, } \\
\text { tidal } \\
\text { flat) }\end{array}$} & \multicolumn{4}{|c|}{ Open marine } \\
\hline & & & & & \multicolumn{3}{|c|}{ Neritic } & \multirow{2}{*}{$\begin{array}{l}\text { Bathyal } \\
\text { (shallow } \\
\text { upper } \\
\text { slope) }\end{array}$} \\
\hline & & & & & Inner & Middle & Outer & \\
\hline $300-940$ & $\ldots$ & $x$ & -- & $x$ & $x$ & -- & & -- \\
\hline $\begin{array}{r}940-3,700 \\
3,7055\end{array}$ & - - & - & - & $x$ & $x$ & $\times$ & $?$ & -- \\
\hline $\begin{array}{l}3,700-3,955 \\
3,955-5,010\end{array}$ & $-\cdots-1$ & - & -- & $\begin{array}{l}x \\
x\end{array}$ & $\bar{x}$ & $x$ & $\bar{x}$ & $\bar{x}$ \\
\hline $5,010-5,298$ & - & -- & -- & & -- & $\hat{-}$ & $\hat{x}$ & 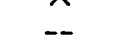 \\
\hline $5,298-5,315$ & - & -- & $x$ & $x$ & -- & -- & -- & -- \\
\hline $5,315-5,700$ & - & -- & -- & -- & -- & $x$ & $\times$ & -- \\
\hline $\begin{array}{l}5,700-5,900 \\
5,900-6,850\end{array}$ & 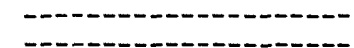 & -- & $\bar{x}$ & $\bar{x}$ & $\bar{x}$ & $\underset{n}{x}$ & -- & -- \\
\hline $6,850-7,020$ & $\begin{aligned}-2-1 \\
-1\end{aligned}$ & - & -. & $\hat{x}$ & -- & - & $\overline{--}$ & $\overline{-}$ \\
\hline $7,020-7,500$ & - & -- & $-\overline{-}$ & - & -- & $\bar{x}$ & $\bar{x}$ & $\bar{x}$ \\
\hline $7,500-7,680$ & - & -- & $\times$ & $\underset{x}{x}$ & $\underset{n}{x}$ & $\bar{v}$ & $\bar{Y}$ & -- \\
\hline $7,680-8,220$ & - & -- & -- & $x$ & $?$ & $x$ & $x$ & -- \\
\hline $8,220-8,970$ & - - & -- & -- & $x$ & $x$ & $\times$ & -- & -- \\
\hline $\begin{array}{l}8,970-9,420 \\
9,420-10,050\end{array}$ & - n & $\bar{x}$ & $\bar{x}$ & $\begin{array}{l}x \\
x\end{array}$ & $\bar{x}$ & $\bar{x}$ & -- & -- \\
\hline $10,050-16,043$ & -0 & $\hat{x}$ & $\hat{x}$ & $\hat{x}$ & -_ & _. & -- & - \\
\hline
\end{tabular}

TABLE 4.-Lithologic log of the COST No. B-2 well

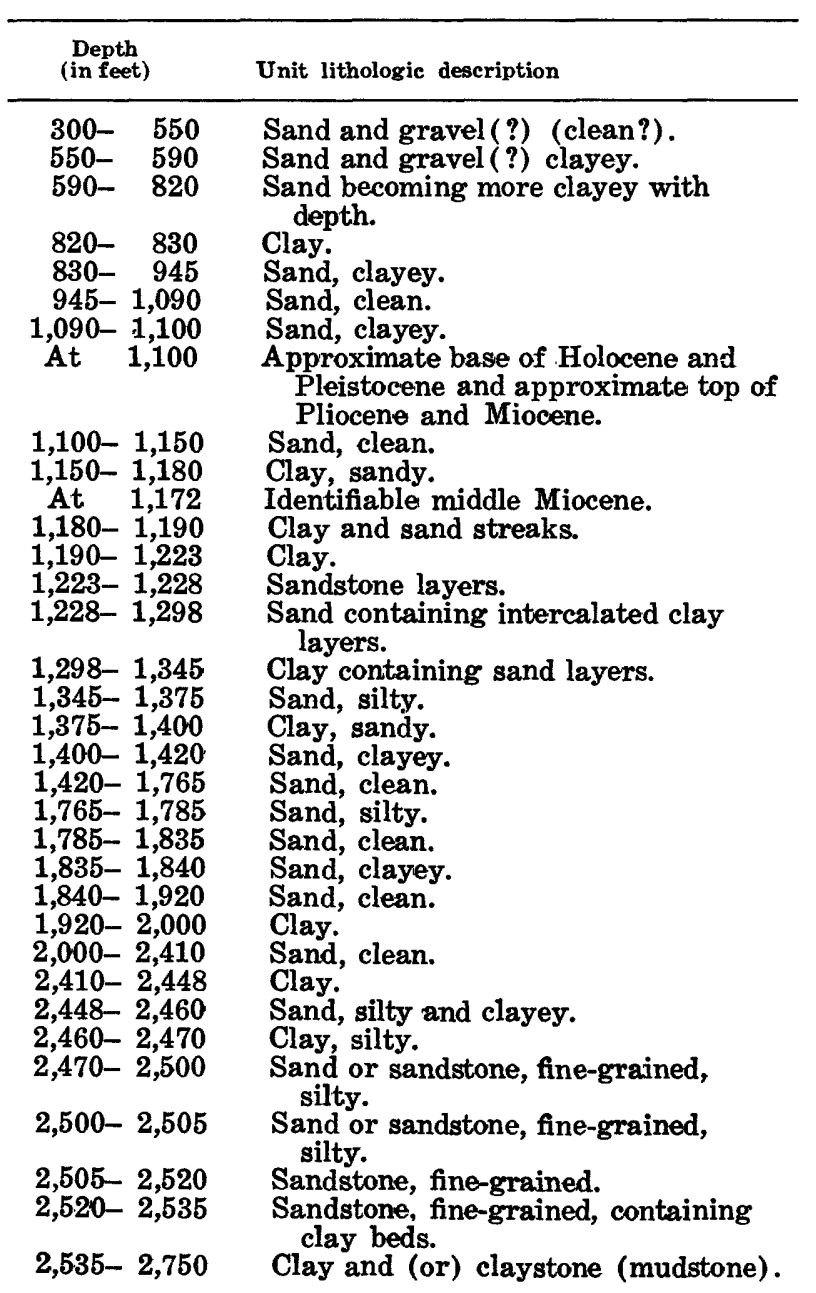

TABLE 4.-Lithologic log of the COST No. B-2 well -Continued

\begin{tabular}{|c|c|}
\hline $\begin{array}{c}\text { Depth } \\
\text { (in feet) }\end{array}$ & Unit lithologic deseription \\
\hline $\begin{array}{l}2,750-2,775 \\
2,775-2,810 \\
2,810-2,945\end{array}$ & $\begin{array}{l}\text { Sandstone, fine-grained, micaceous. } \\
\text { Clay and (or) claystone. } \\
\text { Sandstone, fine-grained, silty and } \\
\text { clayey, micaceous. }\end{array}$ \\
\hline $\begin{array}{l}2,945-3,005 \\
3,005-3,055 \\
3,055-3,065 \\
3,065-3,085\end{array}$ & $\begin{array}{l}\text { Clay and (or) claystone, buff-colored. } \\
\text { Silt and clay and (or) claystone. } \\
\text { Sandstone very fine, silty. } \\
\text { Siltstone and claystone becoming } \\
\text { fine- to medium-grained sandstone } \\
\text { as depth increases. }\end{array}$ \\
\hline $3,085-3,162$ & $\begin{array}{l}\text { Sand and sandstone, medium-grained, } \\
\text { clean, detrital lignite. }\end{array}$ \\
\hline At $\quad 3,162$ & $\begin{array}{l}\text { Sandstone, calcareous and (or) lime- } \\
\text { stone, very sandy. }\end{array}$ \\
\hline $3,162-3,195$ & $\begin{array}{l}\text { Sand and (or) sandstone, mostly } \\
\text { medium-grained, becoming coarse- } \\
\text { grained in places. }\end{array}$ \\
\hline $3,195-3,210$ & Claystone and siltstone. \\
\hline 3,211 & $\begin{array}{l}\text { Limestone, very sandy and (or) sand- } \\
\text { stone, very calcareous. }\end{array}$ \\
\hline $3,212-3,220$ & Sandstone. \\
\hline $3,220-3,235$ & $\begin{array}{l}\text { Clay (probably calcareous claystone, } \\
\text { siltstone, or shale), very sandy } \\
\text { limestone at } 3,230 \text { to } 3,231 \text { feet. }\end{array}$ \\
\hline $\begin{array}{l}3,235-3,240 \\
3,240-3,255 \\
3,255-3,278\end{array}$ & $\begin{array}{l}\text { Sandstone. } \\
\text { Clay and (or) claystone, silty. } \\
\text { Sandstone, fine, medium- to coarse- } \\
\text { grained and silty. }\end{array}$ \\
\hline $3,278-3,280$ & $\begin{array}{l}\text { Limestone, sandy and silty or sand- } \\
\text { stone, silty, very calcareous. }\end{array}$ \\
\hline $3,280-3,500$ & Siltstone, claystone, somewhat sandy. \\
\hline $3,500-3,535$ & $\begin{array}{l}\text { Sandstone, fine-grained, silty and } \\
\text { clayey. }\end{array}$ \\
\hline $3,535-3,546$ & Claystone and (or) siltstone, sandy. \\
\hline $3,546-3,547$ & $\begin{array}{l}\text { Limestone, dark-grayish-brown, } \\
\text { clayey, also siltstone, dark and } \\
\text { calcareous. }\end{array}$ \\
\hline $3,547-3,645$ & Claystone or shale, calcareous. \\
\hline At $\quad 3,596$ & Base of Miocene. \\
\hline
\end{tabular}


TABLE 4.-Lithologic log of the COST No. B-2 well -Continued

\begin{tabular}{|c|c|}
\hline $\begin{array}{c}\text { Depth } \\
\text { (in feet) }\end{array}$ & Unit lithologic description \\
\hline $3,645-3,655$ & $\begin{array}{l}\text { Sandstone, somewhat calcareous and } \\
\text { silty. }\end{array}$ \\
\hline $3,655-3,720$ & $\begin{array}{l}\text { Claystone and siltstone, sandy, } \\
\text { especially from } 3.700 \text { to } 3.720 \text { feet }\end{array}$ \\
\hline $3,720-3,930$ & $\begin{array}{l}\text { Sand, clean, containing many silty } \\
\text { sand intervals. }\end{array}$ \\
\hline $3,930-3,955$ & $\begin{array}{l}\text { Claystone and silty clay, calcareous, } \\
\text { dark-grayish-brown to brown, } \\
\text { possibly somewhat dolomitic. }\end{array}$ \\
\hline $3,955-4,050$ & $\begin{array}{l}\text { Clay or claystone, silty, calcareous } \\
\text { at the top, becoming fine- to } \\
\text { medium-grained sandstone at about } \\
4,000 \text { feet. }\end{array}$ \\
\hline $4,050-4,965$ & $\begin{array}{l}\text { Calcareous mud (marl and possible } \\
\text { chalk), light-gray to buff-colored, } \\
\text { much calcareous sand. }\end{array}$ \\
\hline $\begin{array}{ll}\text { At } & 4,082 \\
\text { At } & 4,964\end{array}$ & $\begin{array}{l}\text { Base of Oligocene. } \\
\text { Base of Eocene. }\end{array}$ \\
\hline $4,965-5,000$ & $\begin{array}{l}\text { Limestone, sandy or calcareous sand- } \\
\text { stones, sandstone at } 4,975 \text { feet. }\end{array}$ \\
\hline $\begin{array}{cr}\text { At } & 5,000 \\
\mathbf{5}, 000 & \mathbf{5 , 1 7 0}\end{array}$ & $\begin{array}{l}\text { Base of Paleocene. } \\
\text { Sandstone, coarse, becoming finer and } \\
\text { more silty with depth. }\end{array}$ \\
\hline At $\quad 5,100$ & Base of Maestrichtian. \\
\hline $5,170-5,200$ & $\begin{array}{l}\text { Sand, fine-grained, silty; possibly } \\
\text { calcareous sandstone. }\end{array}$ \\
\hline At $\quad 5,200$ & Limestone bed (thin). \\
\hline $5,200-5,296$ & $\begin{array}{l}\text { Cay, sity, (siltstone and claystone) } \\
\text { dark-grayish-brown to gray, some } \\
\text { mica present. }\end{array}$ \\
\hline At $\quad 5,296$ & $\begin{array}{l}\text { Limestone bed, thin, light-gray, slight- } \\
\text { ly clayey. }\end{array}$ \\
\hline $5,297-5,300$ & $\begin{array}{l}\text { Sand, fine- to very fine grained, poorly } \\
\text { sorted, clayey, gypsiferous, contain- } \\
\text { ing pyrite fragment (water worn), } \\
\text { glauconite, lignite, fossil fragments, } \\
\text { some limestone fragments. }\end{array}$ \\
\hline $5,300-5,400$ & $\begin{array}{l}\text { Siltstone and claystone, dark-grayish- } \\
\text { black to brown, micaceous. }\end{array}$ \\
\hline $5,400-5,685$ & $\begin{array}{l}\text { Clay and (or) siltstone and claystone } \\
\text { containing some calcareous clay } \\
\text { zones and occasional beds of sand- } \\
\text { stone and calcareous sandstone; } \\
\text { fossiliferous. }\end{array}$ \\
\hline $5,685-5,796$ & $\begin{array}{l}\text { Sandstone, very silty, becoming much } \\
\text { more sandy with depth, micaceous, } \\
\text { slightly calcareous. }\end{array}$ \\
\hline At $\quad 5,736$ & Base of Campanian. \\
\hline $5,796-5,825$ & $\begin{array}{l}\text { Sandstone, silty and containing calcar- } \\
\text { eous sandstone layers at } 5,798 \text { to } \\
\mathbf{5 , 8 2 5} \text { feet. }\end{array}$ \\
\hline $5,825-5,920$ & $\begin{array}{l}\text { Sandstone, silty, becoming less silty } \\
\text { and slightly more calcareous with } \\
\text { depth, a sandy limestone at } 5,918 \\
\text { feet. }\end{array}$ \\
\hline $5,920-5,930$ & Sandstone. \\
\hline $5,930-5,950$ & $\begin{array}{l}\text { Siltstone and claystone, calcareous; } \\
\text { sandy limestone bed at } 5,932 \text { feet. }\end{array}$ \\
\hline $5,950-5,975$ & $\begin{array}{l}\text { Sandstone, fine- to coarse-grained and } \\
\text { silty. }\end{array}$ \\
\hline $5,975-6,060$ & $\begin{array}{l}\text { Sandstone, silty, micaceous and cal- } \\
\text { careous; very sandy limestone beds } \\
\text { at } 5,960 \text { and } 5,990 \text { feet. }\end{array}$ \\
\hline $6,060-6,075$ & Claystone, sandy. \\
\hline $6,075-6,082$ & $\begin{array}{l}\text { Sandstone, clean and porous, shell } \\
\text { fragments. }\end{array}$ \\
\hline $6,082-6,098$ & $\begin{array}{l}\text { Claystone, sandy and calcareous, light- } \\
\text { gray. }\end{array}$ \\
\hline $6,098-6,118$ & $\begin{array}{l}\text { Sandstone, fine- to coarse-grained, } \\
\text { very clean; thin detrital lignite bed } \\
\text { at } 6.110 \text { to } 6.111 \text { feet. }\end{array}$ \\
\hline
\end{tabular}

TABLE 4.-Lithologic log of the COST No. B-2 well -Continued

\begin{tabular}{|c|c|}
\hline $\begin{array}{c}\text { Depth } \\
\text { (in feet) }\end{array}$ & Unit lithologic description \\
\hline $6,118-6,122$ & $\begin{array}{l}\text { Claystone, light-gray, calcareous, lig- } \\
\text { nitic fragments, limonitic and hema- } \\
\text { titic staining. }\end{array}$ \\
\hline $6,122-6,165$ & $\begin{array}{l}\text { Sandstone, clean, porous, lignitic, py- } \\
\text { ritic, calcareous, with fossil frag- } \\
\text { ments. }\end{array}$ \\
\hline $6,165-6,172$ & $\begin{array}{l}\text { Limestone, gray, clayey, sandy, some- } \\
\text { what less calcareous at the base, } \\
\text { glauconite, micas, pyrite nodules, } \\
\text { and lignitic, limonitic, and aragonitic } \\
\text { fragments. }\end{array}$ \\
\hline $6,172-6,240$ & Sand, some very porous (clean). \\
\hline (3) & $\begin{array}{l}\text { Sandstone, fine-grained, silty, and cal- } \\
\text { careous; abundant lignitic and cgaly } \\
\text { fragments at } 6,245 \text { to } 6,250 \text { feet. }\end{array}$ \\
\hline $\begin{array}{l}6,253-6,270 \\
6,270-6,282\end{array}$ & $\begin{array}{l}\text { Sandstone, very porous at } 6,262 \text { feet. } \\
\text { Sandstone, silty, calcareous, containing } \\
\text { some very impure limestones and } \\
\text { dolomitic limestones, chert, glauconite, } \\
\text { lignite, and hematite. }\end{array}$ \\
\hline
\end{tabular}

$6,282-6,338$

$6,338-6,345$

Sandstone, clean, micaceous, lignitic, pyritic; very porous from 6,300 to 6,315 feet.

$6,345-6,478$

Clay, calcareous, micaceous, sandy, gray, some pyrite and detrital lignite.

Sandstone, calcareous, especially at 6,345 feet and from 6,383 to 6,408 feet, clean, porous and coarse grained from 6,410 to 6,460 feet.

At $\quad 6,478$

Limestone very clayey, gray, containing lignitic fragments.

$6,478-6,500$ Sandstone, very calcareous, and (or) limestone, very sandy.

6,500-6,502 Clay, calcareous, possibly a calcareous shale, gray.

$6,502-6,512$

$6,512-6,580$

$6,580-6,595$

6,595- 6,605

6,605- 6,615

6,615- 6,655

$6,655-6,715$

$6,715-6,770$

$6,770-6,795$

6,795- 6,805

$6,805-6,825$

6,825- 6,835

$6,835-6,840$

$6,840-6,847$

6,847- 6,850

$6,850-6,980$

$6,980-6,995$

6,995- 7,005

$7,005-7,018$
Sand, porous.

Shale, and (or) mudstone, sandy, calcareous, dark-gray, micaceous; very calcareous from 6,512 to 6,540 feet.

Sand or sandstone, calcareous.

Clay or shale, very calcareous.

Sandstone, porous, very slightly calcareous.

Clay or shale, sandy and calcareous.

Sandstone, calcareous; gray, silty, calcareous beds at $6,661,6,684$, and 6,713 feet.

Clay and silt, gray to buff, sandy, and very calcareous; shell fragment near the base.

Sandstone, calcareous at 6,775 feet and at 6,791 to 6,795 feet.

Clay or shale, light-gray, sandy, and very calcareous.

Sandstone, slightly calcareous at the top, becoming very porous toward base; lignitic (?) zone at 6,818 feet.

Clay or shale, dark-gray, calcareous.

Sandstone, porous.

Clay or shale, sandy, calcareous, darkgray.

Sandstone, silty, calcareous.

Clay or shale, dark-brownish-gray to gray, calcareous, sandy, gradually becoming very calcareous near the base, detrital lignite, mica.

Sandstone, porous, calcareous; detrital lignite (?) at 6,980 feet.

Silt or siltstone, gray, calcareous.

Clay or shale, light-gray, silty, micaceous, sandy, and calcareous. 
TABLE 4.-Lithologic log of the COST No. B-2 well -Continued

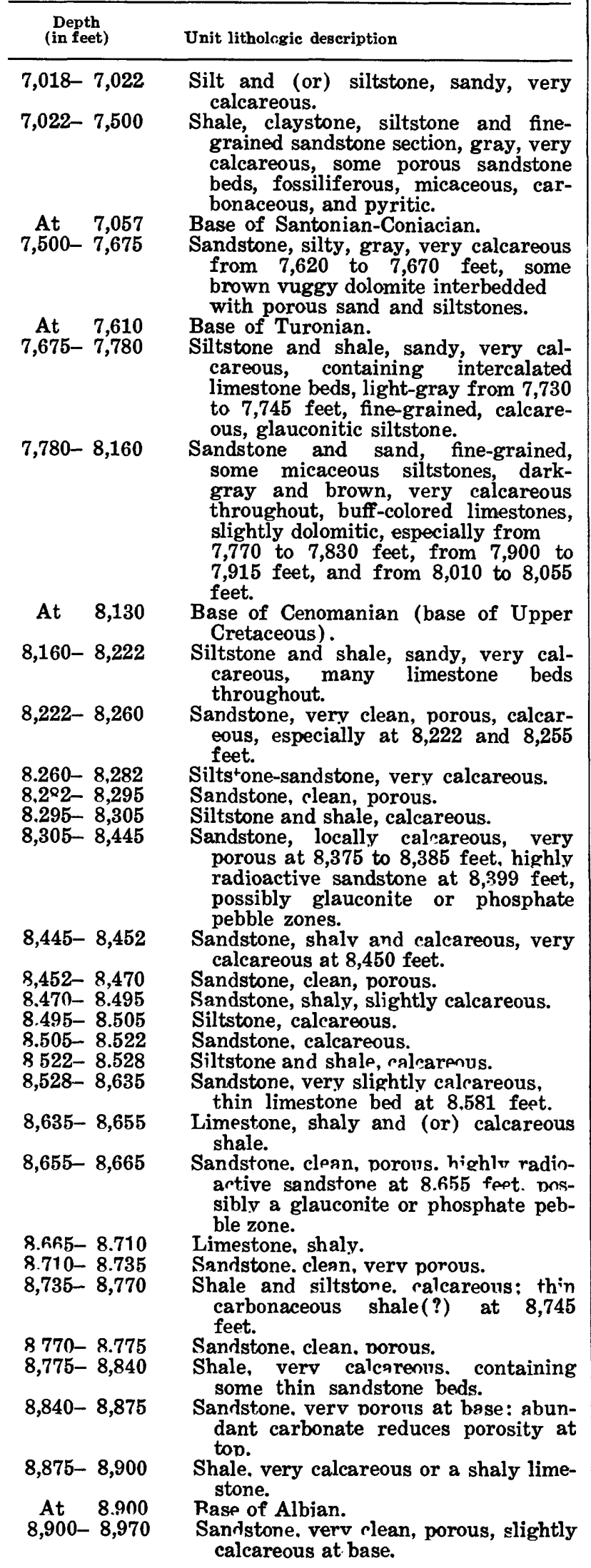

TABLE 4.-Lithologic log of the COST No. B-2 well -Continued

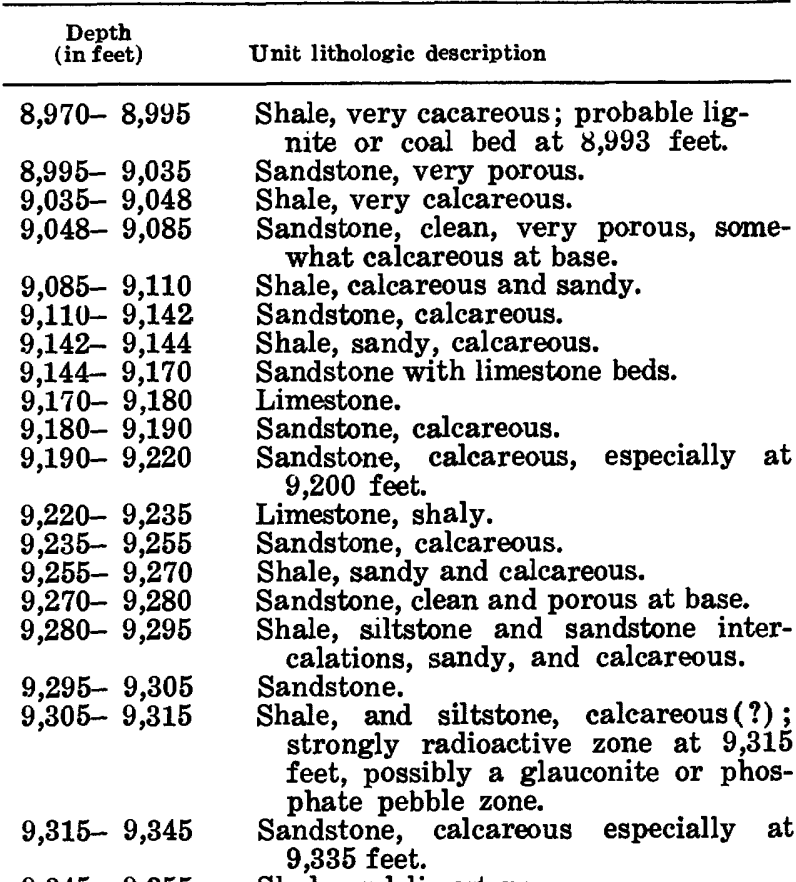

9,345-9,355

$9,355-9,365$

9,365-9,372

$9,372-9,422$

$9,422-9,428$

$9,428-9,431$

$9,431-9,442$

$9,442-9,450$

$9,450-9,462$

$9,462-9,487$

9,487- 9,495

$9,495-9,518$

$\mathbf{9 , 5 1 8}-\mathbf{9 , 5 3 0}$

$9,530-9,610$

$9,610-9,620$

$9,620-9,680$

$9,680-9,725$

$9,725-9,748$

Shale and limestone.

Sandstone.

Shale, rather calcareous.

Sandstone, very porous, clean.

Shale, calcareous.

Shale, washout zone, coal bed at 9,428 feet.

Sandstone.

Shale, washout zone, coal bed at 9,448 feet.

Sandstone, calcareous and shaly.

Sandstone, becoming more porous with depth.

Shale, sandy, very calcareous.

Sandstone, calcareous.

Shale, very calcareous.

Sandstone, clean, highly porous; very radioactive sandstone at 9,585 feet, possibly phosphatic or glauconitic.

Shale, calcareous, sandy.

Sandstone, calcareous at 9,630 feet.

Shale, sandy, very calcareous from 9,708 to 9,725 feet.

Sandstone, porous, interbedded with less porous, carbonate-cemented zones.

$9,748-9,775$

$9,775-9,790$

$9,790-9,820$

$9,820-9,853$

$9,853-9,945$

$9,945-9,958$

$9,958-10,000$

Shale, very calcareous throughout.

Sandstone, porous.

Shale, very calcareous, somewhat sandy at 9,798 feet.

Sandstone, porous, becoming more carbonate cemented toward base.

Limestone, shaly and sandy.

Sandstone, high porosity.

Limestone, shaly and sandy, containing thin beds of sandstone; high radioactivity at 9,900 feet, possibly in glauconitic or phosphatic sandstone.

At 10,000

10,000-10,025

$10,025-10,050$

Base of Aptian.

Sandstone, high-porosity.

Limestone, shaly, some calcareous shales.

$10,050-10.055$

Sandstone. 
TABLE 4.-Lithologic log of the COST No. B-2 well -Continued

Depth
(in feet) $\quad$ Unit lithologic description

$10,055-10,230$

10,230-10,246

$10,246-10,248$

10,248-10,253

10,253-10,303

$10,303-10,306$

10,306-10,325

10,325-10,430

$10,430-10,450$

$10,450-10,456$

10,456-10,480

10,480-10,530

$10,530-10,540$

10,540-10,565

10,565-10,582

10,582-10,610

10,610-10,755

10,755-10,800

10,800-10,805

$10,805-10,820$

10,820-10,835

10,835 10,847

At $\mathbf{1 0 , 8 4 8}$

10,849-10,894

At $\quad \mathbf{1 0}, 895$

10.895-10,906

10,906-10,955

$10.955-10.985$

10,985-11,058

11.05-11.122

11.122-11.135

11,135-11,240

11,240-11,245

11,245-11,338

11,338-11,428

11,428-11,445

$11,445-11,473$

11,473-11,500

$11,500-11,550$

$11,550-11,575$
Limestone, shaly and (or) calcareous shale; washout zone from 10,060 to 10,200 feet probably because of dark carbonaceous shale and coal.

Sandstone.

Coal.

Limestone.

Sandstone, very porous.

Coal and dark shale, iron-oxidestained.

Shale, very calcareous, and (or) shaly limestone.

Sandstone, very porous.

Shale, calcareous, washout; probably a coal seam present.

Sandstone or siltstone.

Shale, calcareous, washout; probably a coal seam present.

Sandstone, very porous.

Shale, calcareous, and shaly limestone layer.

Sandstone.

Shale, calcareous; sandy, probably carbonaceous shale at 10,578 feet.

Sandstone.

Shale, calcareous; a few thin shaly limestones interbedded with thin, fine-grained sandstone; washout at 10,710 and 10,720 feet; coal seams and rounded limestone concretions at 10,732 feet.

Sandstone, porous; washout at 10,800 feet may indicate thin coal seam.

Shale, very carbonaceous.

Sandstone, fair porosity.

Shale, slightly calcareous and (or) shaly limestone.

Sandstone, porous.

Washout, suggests shale containing thin coal seam.

Shale, some sandstone, slightly calcareous, especially at 10,876 feet.

Coal seam.

Sandstone.

Shale, calcareous (especially at $\mathbf{1 0 . 9 1 9}$ feet) : coal seam at 10,927 to 10.928 feet, $\mathrm{Fe}_{2} \mathrm{O}_{3}$ staining; coal at 10,945 feet.

Sandstone. high-porosity. especially at 10.999 feet; nrohable coal seams at 11.000 and 11,042 feet.

Sandstone, verv high porosity.

Shale, calcareous.

Sandstone, porous: calcarenns, nonporous sandstone at 11,200 feet; coal seam at 11,139 feet.

Dolomite(?) or dolomitic limestone (?).

Sandstone, porous, but also tight, containing some calcareous heds, especiallv at 11.220 and 11.300 feet.

Shale. sandv. calcr renus; some limestone, sandv and shalv.

Sandstone, siltstone, dense.

Shale, calcareous, carbonaceous, sandy, and shaly.

Sandstone, clean, porous.

Limestone, shaly to clean, possible dolomitic limestone layers present.

Sandstone, clean, porous, becoming denser at the base.
Shale containing shalv limestone heris,

TABLE 4.-Lithologic log of the COST No. B-2 well -Continued

Depth

(in feet)

$11,575-11,605$

$11,605-11,620$

$11,620-11,635$

$11,635-11,655$

$11,655-11,765$

11,765-11,835

$11,835-11,870$

$11,870-11,880$

$11,880-11,925$

11,925-11,940

11,940-11,975 $11,975-12,030$

At 12,000 12,030-12,045 12,045-12,060

12,060-12,100

12,100-12,112 12,112-12,140 12,140-12,168 $12,168-12,210$ 12,210-12,240

12,240-12,274

12,274-12,282

12,282-12,322

12.322-12.332 1.2,332-12,334

12,334-12,355

12,355-12,402

12,402-12 418

$12.418-12.420$

$12,420-12,430$

$12,430-12,440$ $12,440-12,462$

12,462-12,464 12,464-12,482

12.482-12,492

12.492-12,500

$12.500-12,520$

12,520-12,575

12,575-12,579

12.579-12,595

$12.595-12,621$

12.621-12,625

12,623-12,633

$12,633-12,670$

$12.670-12,708$

12.708-12.715

$12.715-12.845$

12.845-12.856

12,856-12,872
Unit lithologic description

Limestone, in part dolomitic and sandy.

Sandstone, porous; calcareous layer at 11,615 to 11,617 feet.

Shale, very calcareous to shaly limestone.

Sandstone, calcareous, slightly porous. careous sandstone.

Limestone, shaly, alternating with calcareous sandstone.

Sandstone, very porous; calcareous zone at 11,800 feet.

Limestone and (or) shaly limestone.

Sandstone.

Limestone and dolomite(?) at 11,895 feet.

Sandstone, porous to nonporous, calcareous.

Limestone, shaly, and calcareous shale.

Sandstone containing coal bed at 11,980 feet; calcareous at 12,012 feet.

Base of Valanginian.

Limestone, and calcareous shale.

Sandstone, very porous from 12,048 to 12,056 feet.

Limestone, shaly, and calcareous shale; thin sandstone at 12,008 feet.

Sandstone, calcareous.

Limestone, dolomitic.

Sandstone, calcareous.

Limestone, shaly.

Sandstone; high radioactivity at 12,223 feet, possibly because of glauconitic or phosphatic zone.

Limestone, shaly containing conspicuous limestone bed at 12,263 to 12,266 feet.

Sandstone, high radioactivity at 12,276 feet.

Limestone, shalv; dolomitic limestone at about 12.311 feet.

Sandstone, calcareous.

Coal and carbonaceous shales.

Sandstone, calcareous, slightly porous.

Shale, calcareous.

Sandstone, porous.

Coal.

Sandstone, calcareous, changing to sandy limestone as depth increases.

Limestone, dolomitic.

Shale, sandy, calcareous; limestone layers at 12,452 to 12,453 feet; sandstone layer at 12,441 feet.

Shale and coal.

Shale, sandy and somewhat calcareous, becoming more arenaceous as depth increases.

Shale, sandy, calcareous.

Limestone shaly, slightly dolomitic.

Shale, calcareous, sandy near the base.

Shale, calcareous.

Coal, some shaly beds.

Shale, sandy and calcareous.

Sandstone, porous.

Coal.

Sandstone. slightly porous.

Shale, carbonaceous, some coal.

Shale, very calcareous.

Sandstone, calcareous lavers.

Limestone and dolomitic limestone.

Coal and carbonaceous shale.

Shale, very calcareous. 
TABLE 4.-Lithologic log of the COST No. B-2 well -Continued

\begin{tabular}{c}
\hline $\begin{array}{c}\text { Depth } \\
\text { (in feet) }\end{array}$ \\
\hline $12,872-12,890$ \\
$12,890-12,916$ \\
At 12,916 \\
$12,917-13,003$
\end{tabular}

$13,003-13,007$ $13,007-13,075$

$13,075-13,090$

$13,090-13,100$

$13,100-13,138$

13,138-13,140

$13,140-13,160$

$13,160-13,170$

$13,170-13,190$

$13,190-13,200$

$13,200-13,280$

$13,280-13,294$ $13,294-13,302$

13,302-13,330

$13,330-13,350$

$13,350-13,375$

13,375-13,429

13,429-13,440

13,440-13,443

13,443-13,449

13,449-13,452

13,452-13,500

13,500-13,520

13.520-13,524

13,524-13,528

13,528-13,538

13,538-13,555

13,555-13,565

13.565-13,572

13,572-13,574

13,574-13,605

13,605-13,630

13,630-13,642

13.642-13,655

$13,655-13,730$

13,730-13,758

13,758-13,825

13,825-13,890

13,890-13,922

13,922-13,925
Unit lithologic description

Limestone and shale; conspicuous limestone beds at 12,875 to 12,882 teet.

Sandstone, calcareous.

Shale, sandy, carbonaceous.

Limestone, dolomitic, alternating with calcareous sandstone.

Coal.

Alternating calcareous sandstone and limestone beds; limestone becomes more dolomitic as depth increases.

Sandstone and arenaceous limestone.

Sandstone and limestone beds; high radioactivity and limestone at 13,090 feet, possible glauconite or phosphate pebble zone.

Alternating calcareous sandstone and limestone.

Coal bed.

Sandstone and limestone.

Sandstone.

Shale, carbonaceous, coal at 13,179 feet.

Sandstone, tight, slightly calcareous.

Sandstone, clean, porous except at 13,$208,13,225$, and 13,270 feet where calcite cement is especially abundant.

Shale, sandy, calcareous.

Sandstone or siltstone, high radioactivity at 13,292 feet.

Shale, calcareous, carbonaceous at 13,314 feet.

Sandstone, clean, porous, high radio activity at 13,331 feet.

Shale, carbonaceous siltstone.

Sandstone, porous.

Shale, carbonaceous, some siltstone.

Coal

Shale and siltstone, carbonaceous, calcareous (?).

Coal and carbonaceous shale.

Alternating calcareous shale, siltstone, and sandstone; limestone at 14,492 feet.

Sandstone, siltstone, probable siliceous cement.

Coal (?) and carbonaceous shale.

Shale.

Siltstone.

Limestone, sandy; dolomite or dolomitic limestone at 13,543 and 13,548 feet.

Sandstone, moderately porous, shaly.

Siltstone.

Coal seam.

Shale, carbonaceous. alternating with noncalcareous sandstone.

Sandstone, porous, somewhat calcareous at top.

Sandstone, calrareous.

Sandstone, slightly calcareous.

Shale. noncalcareous; calcareous at 13,677 feet.

Shale, becoming less calcareous and more sandy with depth.

Sandstone, clean, porous: limestone beds at 13,759 to 13,760 feet and at 13,808 to 13,810 feet.

Shale, carbonaceous: some siltstone and sandstone layers.

Sandstone, limestone bed at 13,912 to 13,920 feet.

Shale, carbonaceous.

TABLE 4.-Lithologic log of the COST No. B-2 well -Continued

$\underset{\text { (in feet) }}{\text { Depth }}$

$13,425-13,940$

$13,940-14,010$

$14,010-14,055$

14,055-14,070

$14,070-14,098$

$14,098-14,185$

14,185-14,195

$14,195-14,235$

$14,235-14,270$

$14,270-14,360$

$14,360-14,408$

$14,408-14,544$

14,544-14,546

$14,546-14,570$

$14,570-14,608$

$14,608-14,625$

$14,625-14,668$

$14,668-14,697$

$14,697-14,703$

14,703-14,715

14,715-14,745

$14,745-14,753$

$14,753-14,775$

$14,775-14,885$

$14,885-14,890$

14,890-14,943 $14,943-14,968$

$14,968-15,030$

$15,030-15,085$

15.085-15.108

15,108-15,205

$15,205-15,245$

15,245-15,325

$15,325-15,362$

$15,362-15,443$

$15,443-15,476$

$15,476-15,482$
Unit lithologic description

Siltstone.

Shale and sandstone.

Sandstone; limestone at 14,011 and 14,045 feet.

Sandstone or siltstone.

Sandstone, noncalcareous.

Alternating calcareous and noncalcareous sandy shale and siltstone; limestone at 14,111 and 14,133 feet.

Sandstone.

Shale, sandy, in places slightly calcareous; siltstone, noncalcareous, at 14,235 feet.

Sandstone, porous to tight, calcareous (especially at 14,255 feet).

Shale and siltstone, sandy, mostly noncacareous; calcareous at 14,286 , 14,296 , and 14,310 feet, 14,314 to 14,318 feet.

Sandstone, clean somewhat calcareous; impure limestone bed at 14,378 feet.

Shale and siltstone, sandy, calcareous at 14,430 feet.

Coal seam, thin, and fissile shale and siltstone.

Sandstone, clean, slightly calcareous at 14,548 feet.

Shale and siltstone; impure limestone bed at 14,606 to 14,608 feet; shaly sandstone at 14,598 to 14,602 feet.

Sandstone, noncalcareous.

Sandstone, porous and clean, calcareous from 14,638 to 14,645 feet.

Shale and siltstone, dense, sandy, very slightly calcareous; highly carbonaceous at 14,670 feet.

Sandstone, micaceous.

Shale and siltstone, sandy.

Sandstone, calcareous.

Shale and siltstone, sandy.

Sandstone, calcareous.

Shale and siltstone.

Sandstone, probably fine grained, silty, calcareous.

Shale and siltstone.

Sandstone containing very calcareous beds at 14.943 and 14,960 feet.

Shale and siltstone.

Shale and siltstone. arkosic to subarkosic, micaceous, angular; calritecemented sandstone beds at 15,030 feet.

Sandstone, calcareous.

Shale and siltstone, orcasionallv candv; calcareous at 15,110 to 15120 feet; dolomitic limestone at 15,136 to $\mathbf{1 5 . 1 4 0}$ feet.

Sandstone beds, calcareous and noncalcareous, very coarse to medium-grained.

Shale and siltstone, some sandy clavstone.

Sandstone. clean, very coarse. slightly calcite cemented; some beds quartz cemented.

Shale and siltstone: sandstone beds at 15,375 and 15,418 feet.

Sandstone. moderately porous, mostly noncalcareous.

Shale, carbonaceous, and coal. 
TABLE 4.-Lithologic log of the COST No. B-2 well -Continued

\begin{tabular}{|c|c|}
\hline$\underset{\text { (in feet) }}{\text { Depth }}$ & Unit lithologic description \\
\hline $\begin{array}{l}15,482-15,515 \\
15,515-15,595 \\
15,595-15,610 \\
15,610-15,687\end{array}$ & $\begin{array}{l}\text { Sandstone, mostly noncalcareous. } \\
\text { Shale, siltstone. } \\
\text { Shale, sandy, and shaly sandstone. } \\
\text { Shale and siltstone, probably several } \\
\text { thin coal seams. }\end{array}$ \\
\hline $15,687-15,705$ & $\begin{array}{l}\text { Sandstone, sparse to abundant cal- } \\
\text { careous cement. }\end{array}$ \\
\hline $15,705-15,805$ & $\begin{array}{l}\text { Shale, siltstone, and claystone, in- } \\
\text { terbedded with occasional thin sand- } \\
\text { stone beds. }\end{array}$ \\
\hline $15,805-15,865$ & $\begin{array}{l}\text { Sandstone, calcareous, coarse-grained } \\
\text { sand to gravel. }\end{array}$ \\
\hline $\begin{array}{l}15,865-15,882 \\
15,882-15,895\end{array}$ & $\begin{array}{l}\text { Shale and siltstone. } \\
\text { Sandstone, slightly calcareous, coarse- } \\
\text { grained. }\end{array}$ \\
\hline $15,895-15,950$ & $\begin{array}{l}\text { Sandstone, calcareous and noncal- } \\
\text { careous (alternating). }\end{array}$ \\
\hline $15,950-15,997$ & 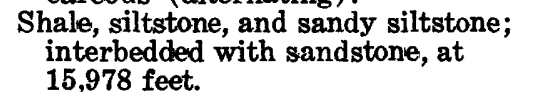 \\
\hline $15,997-16,043$ & $\begin{array}{l}\text { Sandstone, low porosity in places } \\
\text { but vuggy and fairly porous else- } \\
\text { where, very coarse to medium- } \\
\text { grained, calcareous to noncal- } \\
\text { careous, some siliceous cement. }\end{array}$ \\
\hline
\end{tabular}

and claystone), and carbonate rocks. Groupings of these rock types (table 5) are made to provide an insight into the amounts of reservoir rock available. Certain parts of the shaly section above 9,100 feet and of the sandstone section below 9,100 feet, are very calcareous and have low porosity and high density; these particular calcareous shales and sandstones are classified with the limestone and dolomite grouping. Figure 7 is a graph showing the various measured, adjusted, and combined percentages of these three groupings of rock types penetrated in 1,000-foot intervals.

The dominance of sandstone and shale in the Baltimore Canyon trough is apparent. In fact, significant numbers of sandstone reservoirs and impermeable capping shales exist throughout the rock column, except perhaps for the 7,1008,100-foot interval. Most of the sandstone beds are thicker than 10 feet, and some sandstone sections are more than $\mathbf{1 0 0}$ feet thick (see table 4). Table 5 shows that a major part of the section below 5,100 feet (essentially the Cretaceous section) is composed of sandstone. However, as shown in the following discussion dealing with sandstone porosities, a significant percentage of this sandstone has low porosity.

TABLE 5.-Sand, shale, and carbonate content in the COST No. B-2 well

[Values in parentheses are the actual measured values of shale and (or) sand lithology before subtraction of calcareous units, values in percent]

\begin{tabular}{|c|c|c|c|}
\hline \multirow[b]{2}{*}{ Interval (feet) } & \multicolumn{3}{|c|}{ Major lithologies } \\
\hline & $\begin{array}{c}\text { Sand } \\
\text { sandstone }\end{array}$ & $\begin{array}{l}\text { Clay, shale } \\
\text { siltstone and claystone }\end{array}$ & $\begin{array}{l}\text { Limestone, dolomite, } \\
\text { calcareous shale, } \\
\text { and (or) sandstone } 1\end{array}$ \\
\hline
\end{tabular}

1 Dense (low-porosity) calcareous zones are subtracted from the shale categories in most footages above 9,100 feet. Below 9,100 feet, the dense calcareous zones are subtracted from the sandstone column. 


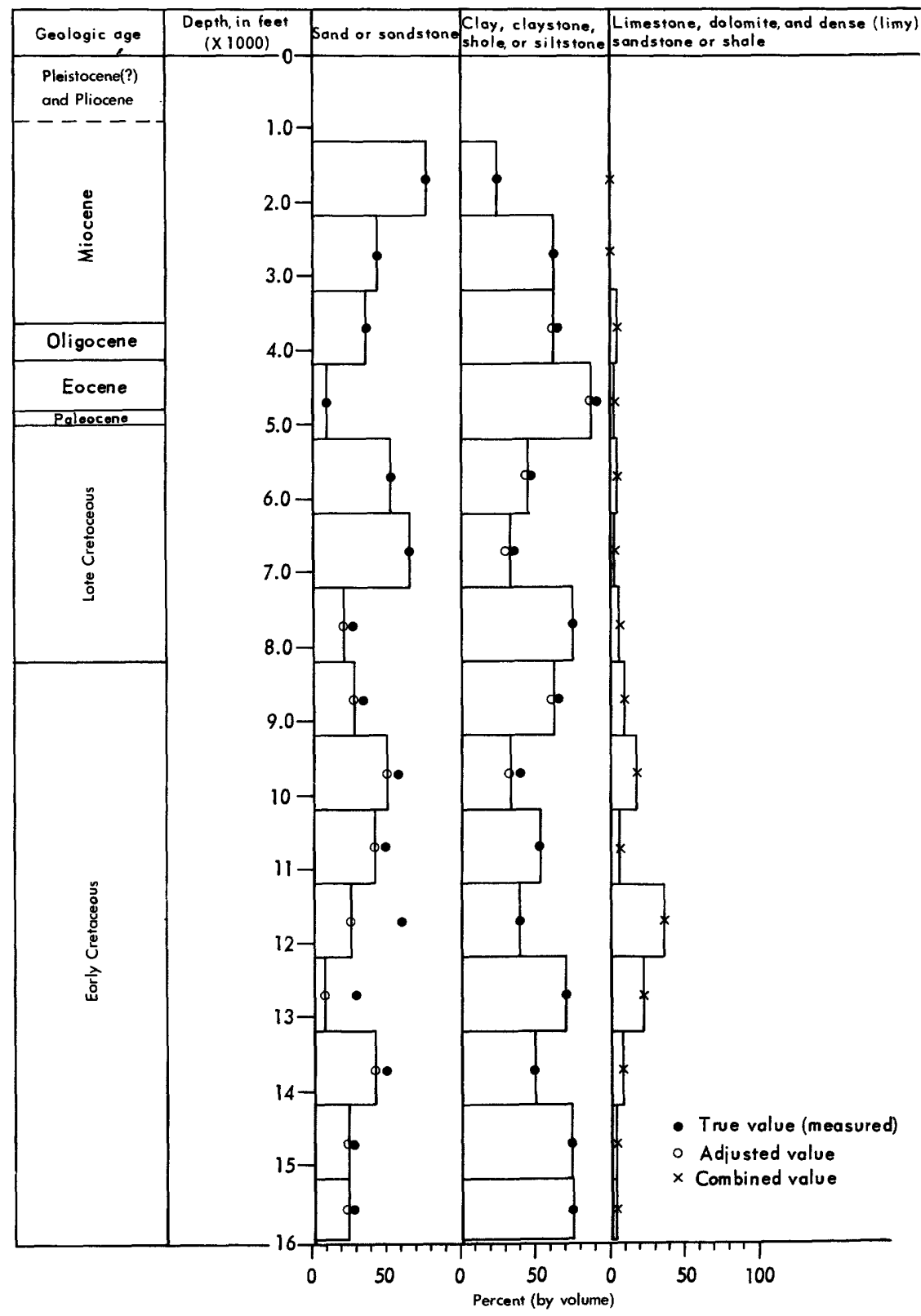

FigURE 7.-Sand, shale, and carbonate content as a function of depth. Carbonate column includes dense, calcareous sandstones or shales. True values refer to the actual amounts of sand or shale measured; adjusted values are those derived by subtracting strongly calcareous units; combined values are given where the total carbonate amount is a combination of limestones, limy shales, and calcareous sands. 


\section{Sandstone Porosities}

By E. C. Rhodehamel

Sandstone-porosity $(\phi)$ values were derived from the BHC (sonic), FDC (density), and CNL (neutron) logs. Rather good agreement exists between porosity values determined from the sonic $\left(\phi_{\mathrm{s}}\right)$, and density $\left(\phi_{\mathrm{d}}\right) \operatorname{logs}$. However, the CNL-FDC (neutron and density) log showed that the neutron porosities $\left(\phi_{n}\right)$ were generally 2 to 30 percent higher than the $\phi_{\mathrm{d}}$ values. Because the $\phi_{\mathrm{d}}$ was calculated on the basis of sandstone densities, the calcareous zones, and particularly the dolomitic zones, tended to provide apparently low $\phi_{\mathbf{d}}$ values. On the other hand, the neutron log tends to measure true porosity as long as the major source of hydrogen is in the form of water or oil. When other sources of hydrogen (that is, lignite, coal, or bound waters in shale, gypsum, and cristobalite) are present, the neutronporosity log measures inordinately high porosities. The presence of natural gas, on the other hand, leads to incorrectly low $\phi_{n}$ values. The disparity between $\phi_{\mathrm{d}}$ and $\phi_{\mathrm{n}}$-is therefore accentuated in these zones. As the $\phi_{n}$ values were judged to be too high throughout much of the section, these porosities were not tabulated.

Figure 8 shows the plots of $\phi_{\mathrm{a}}$ and $\phi_{\mathrm{s}}$ versus depth. These data are taken on the average of about 200-foot intervals from the more extensive tabulations of $\phi_{\mathrm{d}}$ and $\phi_{\mathrm{s}}$ given in table 6.

The values of $\phi_{\mathrm{d}}$ and $\phi_{\mathrm{s}}$ are in reasonably good agreement throughout the entire section. $\phi_{\mathrm{d}}$ values range from 68 percent at about 2,000 feet to 2 percent at 16,007 feet. $\phi_{s}$ values range from 55 percent in a poorly consolidated section at about 1,400 feet to 6 percent at about 15,000 feet. Both logs show decreasing porosity as depth increases. Reduction in porosity with depth is to be expected in mineralogically immature sediments because of sediment compaction resulting from overburden pressure increase, as well as progressive cementation. Table 6 also presents porosity values determined by Core Laboratories (Smith and others, 1976). The porosity values were directly measured on conventional and sidewall cores. Corresponding permeability values (fig. 5) were calculated from a plot of the grain size, shaliness, and permeability relationships of Gulf Coast samples.

The conventional core analyses (table 6) show a decrease in porosity with increased burial depth very similar to that noted in the log values; the permeabilities show a correspondingly rapid decrease with depth. The sidewall-core porosity values, on the other hand, show less of a decrease with progressive burial, and at the base of the well, these values were considerably higher than porosities determined by $\log$ analysis.

The section "Lithologic Description" notes that about 50 percent of the Cretaceous section in the B-2 well consists of rather thick sandstone units. These units have porosities ranging from about 41 percent at 5,700 feet (near the top of the Cretaceous) to about 4 percent near the base of the test hole. However, as shown by the data in table 6, the major part (as much as 75 percent) of the Cretaceous sandstone section has less favorable reservoir characteristics (porosities less than 10-15 percent), especially in deeper parts of the well. 


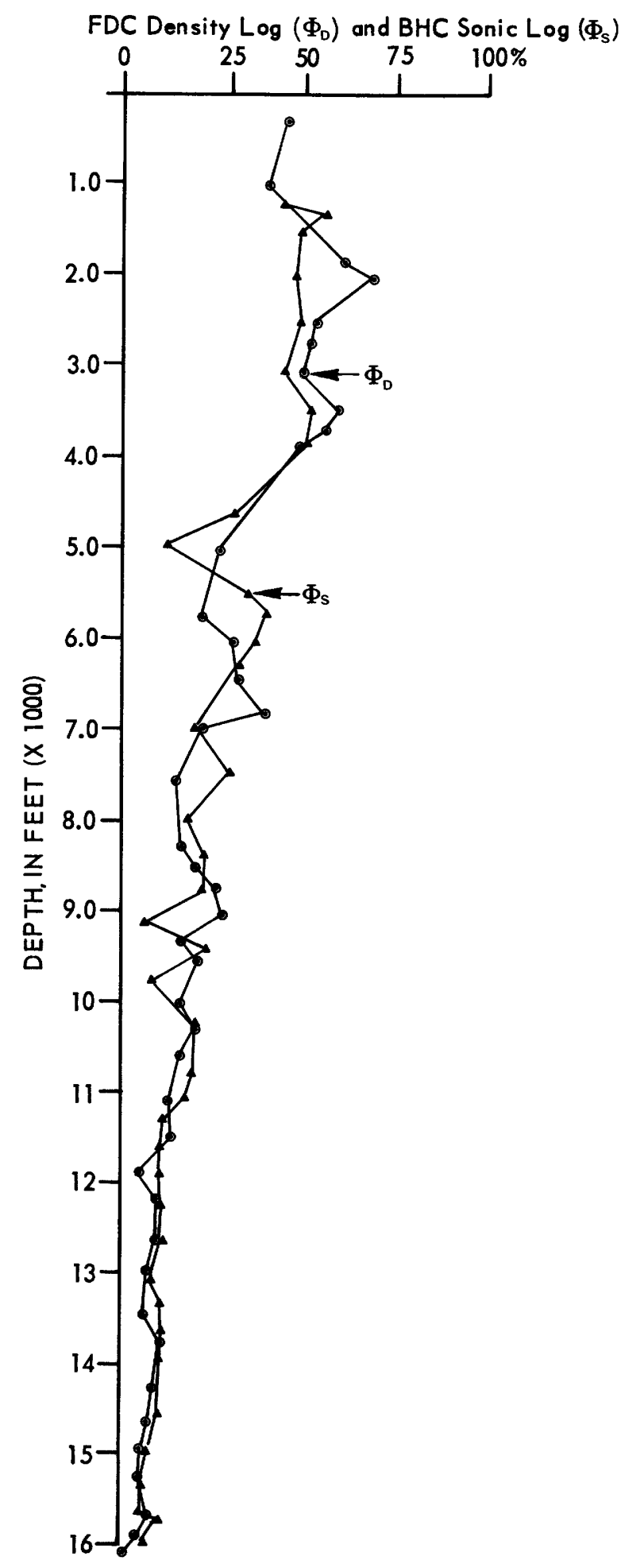

FIGURE 8.-Density and sonic log porosity as a function of depth. 
TABLE 6.-Comparison of porosity $(\phi)$ values determined from electric log and core measurements on COST No. $B-2$ well samples

[Core $\phi$ data from Core Laboratories, Inc. (Smith and others, 1976). Asterisk denotes determination from sidewall core samples]

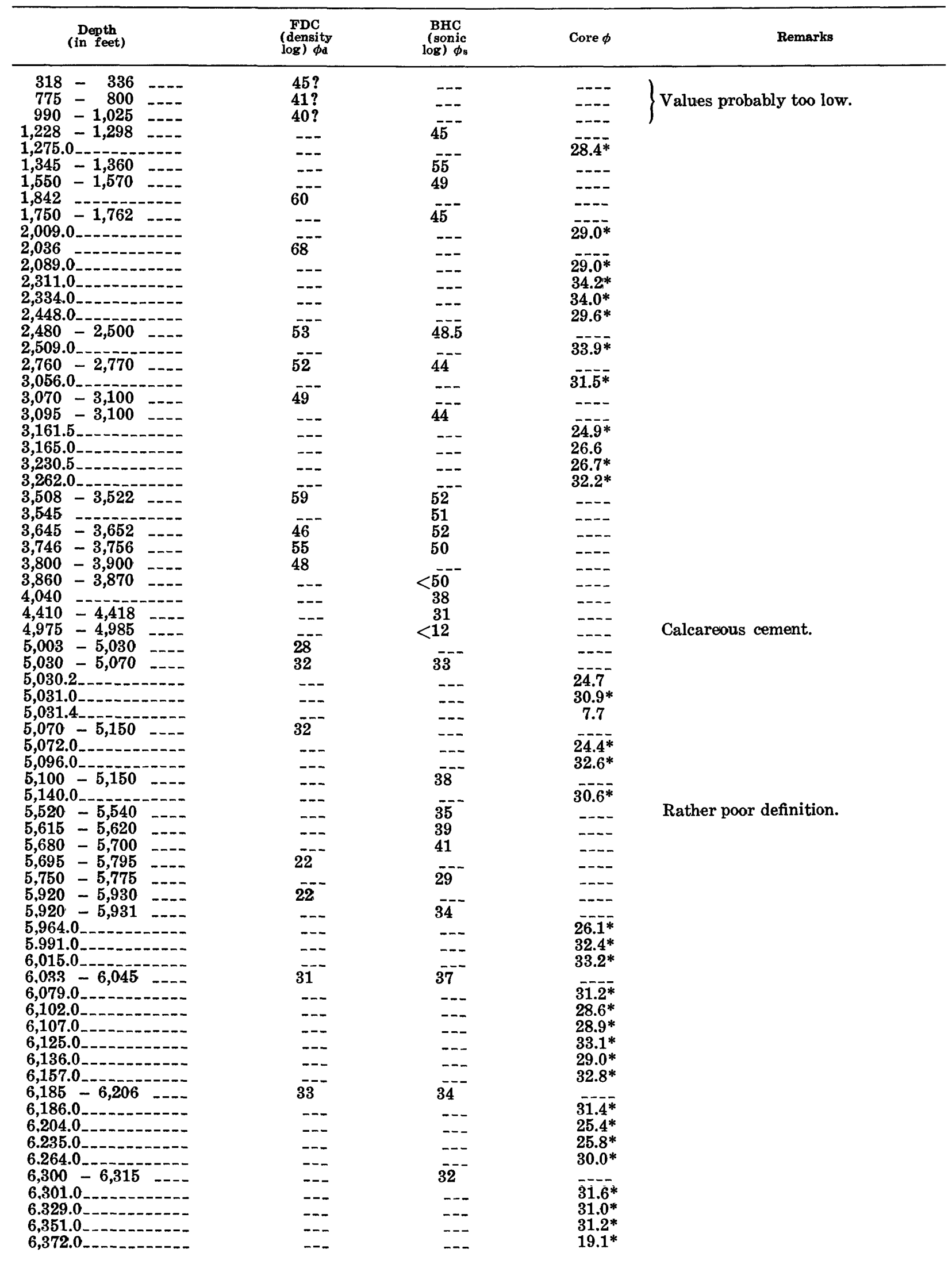


TABLE 6.-Comparison of porosity ( $\phi$ ) values determined from electric log and core measurements on COST No. $B-2$ well samples-Continued

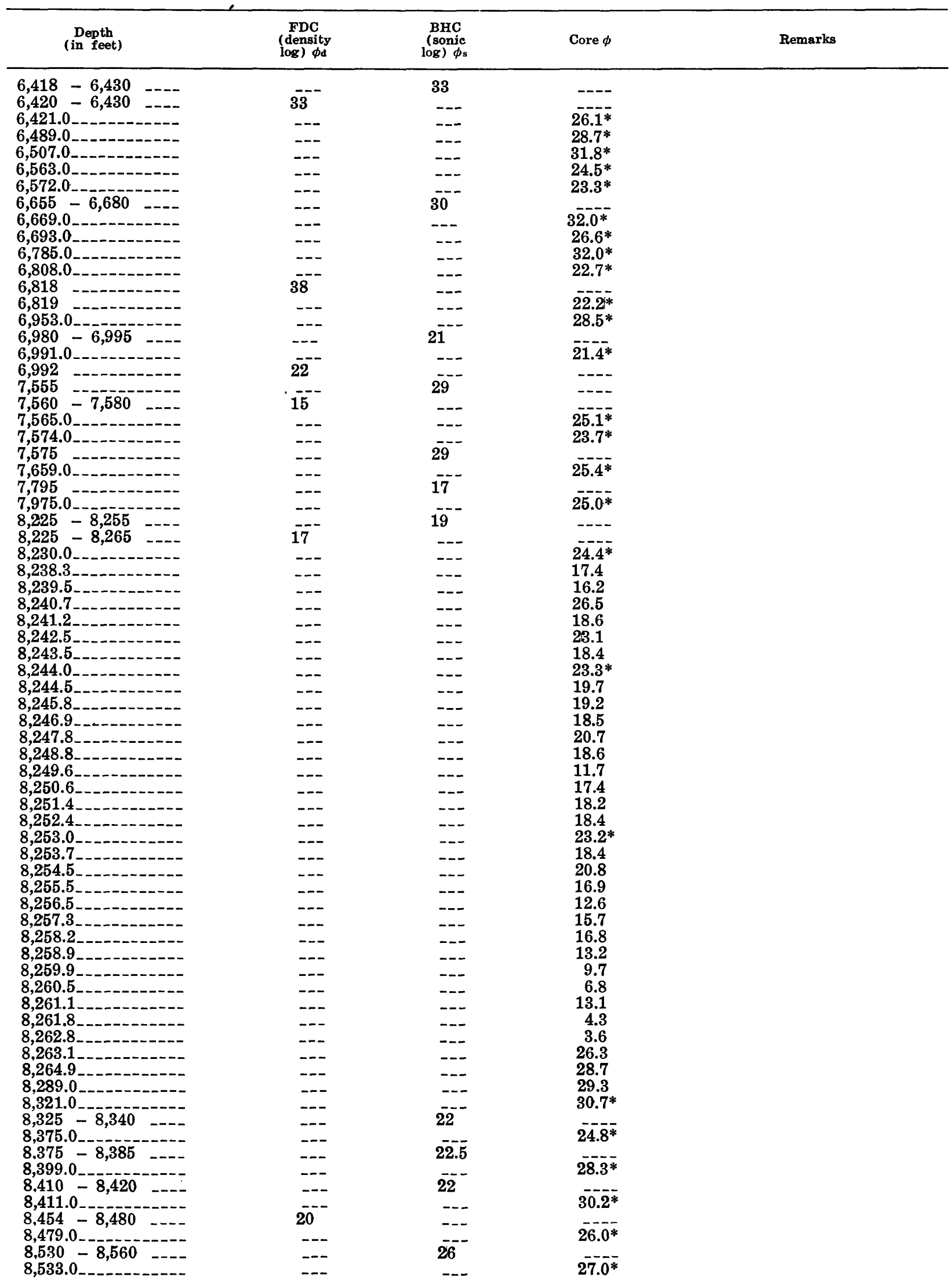


TABLE 6.-Comparison of porosity ( $\phi$ ) values determined from electric log and core measurements on COST No. $B-2$ well samples-Continued

\begin{tabular}{|c|c|c|c|c|}
\hline $\begin{array}{l}\text { Depth } \\
\text { (in feet) }\end{array}$ & $\begin{array}{c}\text { FDC } \\
\text { (density } \\
\log )_{\phi d}\end{array}$ & $\begin{array}{c}\text { BHC } \\
\text { (sonic } \\
\log \phi_{\mathrm{s}}\end{array}$ & Core $\phi$ & Remarks \\
\hline 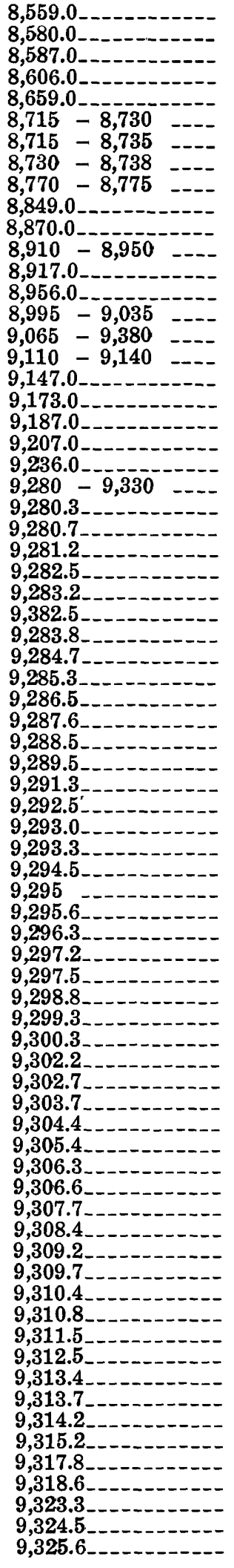 & 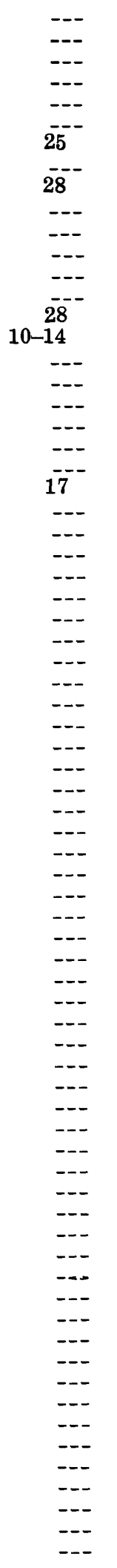 & 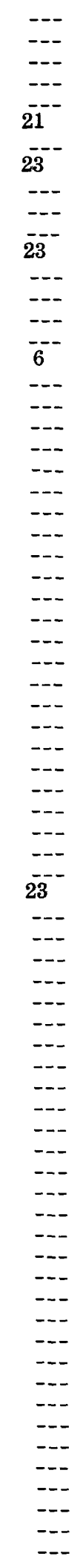 & 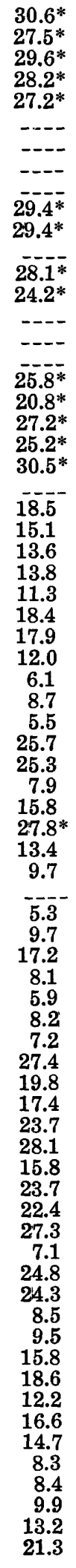 & Fractured. \\
\hline
\end{tabular}


TABLE 6.-Comparison of porosity ( $\phi$ ) values determined from electric log and core measurements on COST No. $B-2$ well samples-Continued

\begin{tabular}{|c|c|c|c|c|}
\hline (in feet) & $\begin{array}{c}\text { FDC } \\
\begin{array}{c}\text { (density } \\
\text { log } \phi) \phi d\end{array}\end{array}$ & $\begin{array}{c}\text { BHC } \\
\text { (sonic } \\
\log \phi_{\mathrm{s}}\end{array}$ & Core $\phi$ & Remarks \\
\hline 9,326.4 & -- & --- & 23.2 & \\
\hline $9,327.6$ & -- & --- & 20.8 & \\
\hline $9,328.4$ & --- & --- & 17.9 & \\
\hline $9,329.6$ & -- & --- & 24.4 & \\
\hline $9,357.0$ & -- & -- & $27.0^{*}$ & \\
\hline $\begin{array}{l}9,362-9,412 \\
9,402-9,15\end{array}$ & 24 & $\overline{23.5}$ & --- & \\
\hline $\begin{array}{l}9,402-9,415--- \\
9,467.0\end{array}$ & --- & $\begin{array}{r}23.0 \\
---\end{array}$ & $9.8^{*}$ & \\
\hline $9,530-9,610$ & 21 & --- & 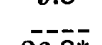 & \\
\hline $9,534.0$ & --- & --- & $26.8^{*}$ & \\
\hline $9,539.0-1-1--$ & --- & --- & $23.7^{*}$ & \\
\hline $\begin{array}{l}9,545.0 \\
9,550-9,580\end{array}$ & --- & $\overline{20 . \overline{5}}$ & $27.3^{*}$ & \\
\hline $9,569.0$ & -- & -- & $28.5^{*}$ & \\
\hline $9,597.0$ & --- & --- & $9.9 *$ & \\
\hline $9,623.0$ & --- & --- & $19.3^{*}$ & \\
\hline $9,635.0$ & -- & $>19$ & $27.5^{*}$ & \\
\hline $\begin{array}{l}9,655-9,660- \\
9,659,0\end{array}$ & -- & $>19$ & $20^{*}$ & \\
\hline $\begin{array}{l}9,659.00,0 \\
9,728.5\end{array}$ & $\begin{array}{l}--- \\
---\end{array}$ & --- & $\begin{array}{l}28.2^{*} \\
29.9^{*}\end{array}$ & \\
\hline $9,748.0$ & -- & --- & $27.8^{*}$ & \\
\hline $9,770-9,778$ & --- & --- & 9.0 & \\
\hline 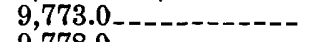 & -- & -- & $20.4^{*}$ & \\
\hline $9,778.0$ - & -- & & $22.5^{*}$ & \\
\hline & 13 & 32.5 & $-\cdots$ & \\
\hline $\begin{array}{l}9,820-9,835 \\
9,825.0\end{array}$ & 10 & -- & $27.8^{*}$ & \\
\hline 9,882 - & -- & $8^{---}$ & & \\
\hline $9,918.0$ & -- & & $30.1^{*}$ & \\
\hline $9,953.0$ & --- & 32.5 & $22.8^{*}$ & \\
\hline $\begin{array}{r}9,978 \\
10,000\end{array}$ & & $<8$ & --- & \\
\hline $10,000{ }_{10}-10,025$ & 16 & --- & $\overline{270 *}$ & \\
\hline $10,051.0$ & -- & -- & $24.4^{*}$ & \\
\hline $10,230 \quad-10,245 \quad \ldots$ & 17.4 & -- & -- & \\
\hline $10,253-10,303 \quad \ldots$ & 20 & $--=$ & $-\cdots$ & \\
\hline $10,255-10,290$ &.- & 19.5 & ---- & \\
\hline $10,256.0$ & & --- & $22.4^{*}$ & \\
\hline $\begin{array}{l}10,325 \\
10,346.0\end{array}-10,428$ & 16 & --- & $\overline{21.7^{*}}$ & \\
\hline $10,350-10,430$ & -- & $<1 \overline{8}^{--}$ & ---- & \\
\hline 10,409.0 & -- & --- & $20.8^{*}$ & \\
\hline $10,429.0$ & -- & & $21.8^{*}$ & \\
\hline $\begin{array}{l}10,490 \quad-10,530 \quad--- \\
10,499,0\end{array}$ & -- & $>20$ & $20 *$ & \\
\hline $\begin{array}{l}10,499.0 \\
10,555.0\end{array}$ & -- & --- & $\begin{array}{l}20.9^{*} \\
17.2^{*}\end{array}$ & \\
\hline $10,555.0-10,610$ & 16 & -- & -.-- & \\
\hline $10,595-10,610$ & -.. & $>20$ & --- & \\
\hline $10,770-10,780$ & -- & $>20$ & --- & \\
\hline $10,791.0$ & & -- & $26.5^{*}$ & \\
\hline $10,805-10,820$ & 18 & --- & $\overline{23} 8^{7}$ & \\
\hline $\begin{array}{l}10,817.0--------- \\
10,899.0\end{array}$ & -- & --- & $\begin{array}{l}23.7^{*} \\
24\end{array}$ & \\
\hline $10,960-10,980$ & -- & $20^{--}$ & $24.7^{4}$ & \\
\hline $10,967.0$ & -- & -- & $21.5^{*}$ & \\
\hline 11,035 & 12 & --- & & \\
\hline $11,037.0$ & 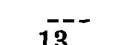 & --- & $22.7^{*}$ & \\
\hline $\begin{array}{lll}11,058 & -11,122 & --- \\
11,060 & -11,115\end{array}$ & 13 & $<\overline{18}^{--}$ & --- & \\
\hline $11,064.0$ & -- & -- & $24.0^{*}$ & \\
\hline $11,102.0$ & -- & & $22.0^{*}$ & \\
\hline $11,115-11,130$ & --- & $<12$ & & \\
\hline $11,141.0$ & -- & -- & $20.3^{*}$ & \\
\hline $11,173.0$ & -- & & $18.5^{*}$ & \\
\hline $11,205-11,230$ & -- & $<12$ & $050 *$ & \\
\hline $\begin{array}{l}11,216.0 \\
11,255-11,265\end{array}$ & --- & $<\overline{12}^{--}$ & $25.0^{*}$ & \\
\hline $11,257.0$ & -- & & $24.4^{*}$ & \\
\hline $11,280-11,295$ & -- & 12 & --- & \\
\hline $11,310-11,320$ & --- & 19 & $\ldots-$ & \\
\hline $11,384.0$ & -- & & $20.7^{*}$ & \\
\hline 11,385 & --- & 11 & & \\
\hline
\end{tabular}


TABLE 6.-Comparison of porosity $(\phi)$ values determined from electric log and core measurements on COST No. B-2 well samples-Continued

\begin{tabular}{|c|c|c|c|c|}
\hline $\begin{array}{c}\text { Depth } \\
\text { (in feet) }\end{array}$ & $\begin{array}{c}F D C \\
\begin{array}{c}\text { (density } \\
\text { log) } \phi \mathrm{d}\end{array}\end{array}$ & $\begin{array}{c}\underset{\text { (sonic }}{\mathbf{B H C}} \\
\log \phi_{\mathbf{S}}\end{array}$ & Core $\phi$ & Remarks \\
\hline $11,424-11,434 \quad---$ & --- & 19 & & \\
\hline $11,435.0$ & -- & -- & $18.8^{*}$ & \\
\hline $11,476-11,496---$ & 13 & --- & $2 \overline{8 *}$ & \\
\hline 11,483.0.0. & $\begin{array}{l}--- \\
---\end{array}$ & $\begin{array}{l}--- \\
---\end{array}$ & $20.2^{*}$ & \\
\hline $11,559.0$ & -- & -- & $22.3^{*}$ & \\
\hline $11,607.0$ & -- & --- & $18.3^{*}$ & \\
\hline $\begin{array}{lll}11,635 & -11,652 & - \\
11,638 & -11,655\end{array}$ & 6 & $\overline{11.5}$ & --- & \\
\hline $\begin{array}{lll}11,638 & -11,655 & - \\
11,780 & -11,800 & -\end{array}$ & --- & ${ }_{12}^{11.5}$ & --- & \\
\hline $11,870-11,880$ & $5^{---}$ & $<12$ & $-\cdots$ & \\
\hline $\begin{array}{l}11,873.0 \\
11,928-11,938\end{array}$ & --- & -- & $20.7^{*}$ & \\
\hline $\begin{array}{lll}11,928 & -11,938 & - \\
11,975 & -\end{array}$ & $\begin{array}{l}10 \\
14\end{array}$ & -- & --- & \\
\hline $11,980-12,002$ & --- & 12 & --- & \\
\hline $11,981.0$ & -- & -- & 18.9 & \\
\hline $\begin{array}{l}11,984{ }^{-12,028} \\
11,999.0\end{array}$ & 11 & -- & $16.5^{\bar{k}}$ & \\
\hline $12,021.0$ & -- & --- & $12.6 *$ & \\
\hline $\begin{array}{lll}12,050 & -12,055 & -\end{array}$ & --- & 20 & $101 \%$ & \\
\hline $12,135-12,150$ & --- & $<\overline{12}^{--}$ & $19.1^{*}$ & \\
\hline $12,139.0$ & -- & -.. & $\overline{17.2 *}$ & \\
\hline $\begin{array}{l}12,155-12,165 \\
12,157.0\end{array}$ & --- & 19 & $180 *$ & \\
\hline $12,214-12,220$ & $10^{--}$ & --- & $18.0^{*}$ & \\
\hline $12,215-12,245$ & -- & $<1 \overline{2}^{--}$ & --- & \\
\hline $12,218.0$ & $8^{---}$ & - & $15.4^{*}$ & \\
\hline 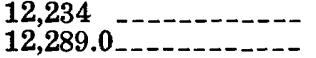 & 8 & -- & $116^{*}$ & \\
\hline $12,400-12,420$ & --- & $12-$ & $\begin{array}{l}11.6^{*} \\
----\end{array}$ & \\
\hline $12,402-12,417$ & 12 & -- & ---- & \\
\hline $12,515.0-12,620$ & 10 & --- & $20.4^{*}$ & \\
\hline $12,597.0$ & 10 & --- & $1 \overline{2.5} \bar{F}^{*}$ & \\
\hline $12,600-12,615$ & -- & 11.5 & 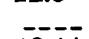 & \\
\hline $12,627.0$ & -- & 11 & $18.1^{*}$ & \\
\hline 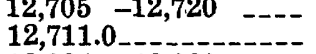 & $\overline{---}$ & 11 & $19.7^{*}$ & \\
\hline $12,984 \quad-12,989 \quad-$ & 8 & --- & --- & \\
\hline $\begin{array}{lll}13,070 & -13,095 & ---\end{array}$ & 4 & 8 & --- & \\
\hline $\begin{array}{l}13,075,0 \\
13,083.0\end{array}$ & $\begin{array}{l}4 \\
---\end{array}$ & $\begin{array}{l}--- \\
---\end{array}$ & $21 . \overline{2}$ & \\
\hline 13,085 & 4 & -- & --- & \\
\hline $13,094 \quad-13,170$ & 8 & $10^{-}$ & --- & \\
\hline $\begin{array}{l}13,1500^{-13,170}-\cdots \\
13,165.0\end{array}$ & $\begin{array}{l}--- \\
---\end{array}$ & 10 & $21 . \overline{1} *$ & \\
\hline $13,195-13,260$ & $0--$ & $<12$ & $-\cdots$ & \\
\hline & 8 & --- & $-\overline{-6 *}$ & \\
\hline $\begin{array}{l}13,217.00- \\
13,243.0\end{array}$ & -- & --- & $\begin{array}{l}23.6^{*} \\
18.2^{*}\end{array}$ & \\
\hline $13,295-13,300$ & -- & $<1 \overline{1}^{--}$ & & \\
\hline & -- & --- & $22.1^{*}$ & \\
\hline $\begin{array}{lll}13,380 & -13,440 & --- \\
13,390 & -13,400 & -\end{array}$ & $\begin{array}{l}\mathbf{9 . 2} \\
---\end{array}$ & $<\overline{12--}$ & ---- & \\
\hline $13,409.0$ & --- & -- & $21.0^{*}$ & \\
\hline $13,410-13,430$ & $7^{---}$ & $<13$ & --- & \\
\hline $\begin{array}{l}13,420,-13,440 \\
13,420.2\end{array}$ & 7 & -- & $12.8-$ & \\
\hline $13,421.6$ & -- & - & 13.1 & \\
\hline $13,422.4$ & --- & $\ldots$ & 10.9 & \\
\hline $13,423.3$ & --- & -- & 12.5 & \\
\hline $13,424.3$ & --- & -.- & 14.0 & \\
\hline $13,425.0-13,425.4 \ldots$ & -.- & -- & 13.7 & Pinpoint fluorescence, weak odor. \\
\hline $13,425.8$ & --- & --- & 12.5 & \\
\hline $13,425.9-13,426.0$ & --- & $-\ldots$ & 16.0 & Pinpoint fluorescence, weak odor. \\
\hline $13,426.8$ & --- & -.- & 13.6 & \\
\hline $13,427.6$ & -- & $-\overline{-}$ & 11.4 & \\
\hline $13,427.0-13,428.0$ & -- & $\ldots$ & 12.7 & Pinpoint fluorescence, weak odor. \\
\hline $13,428.3-1-1-1-$ & --- & --- & 13.9 & \\
\hline $13,428.0-13,429.0_{\ldots}---$ & --- & - & 16.4 & Pinpoint fluorescence, weak odor. \\
\hline $13,429.3$ & --- & -_- & 11.5 & \\
\hline
\end{tabular}


TABLE 6.-Comparison of porosity $(\phi)$ values determined from electric log and core measurements on COST No. B-2 well samples-Continued

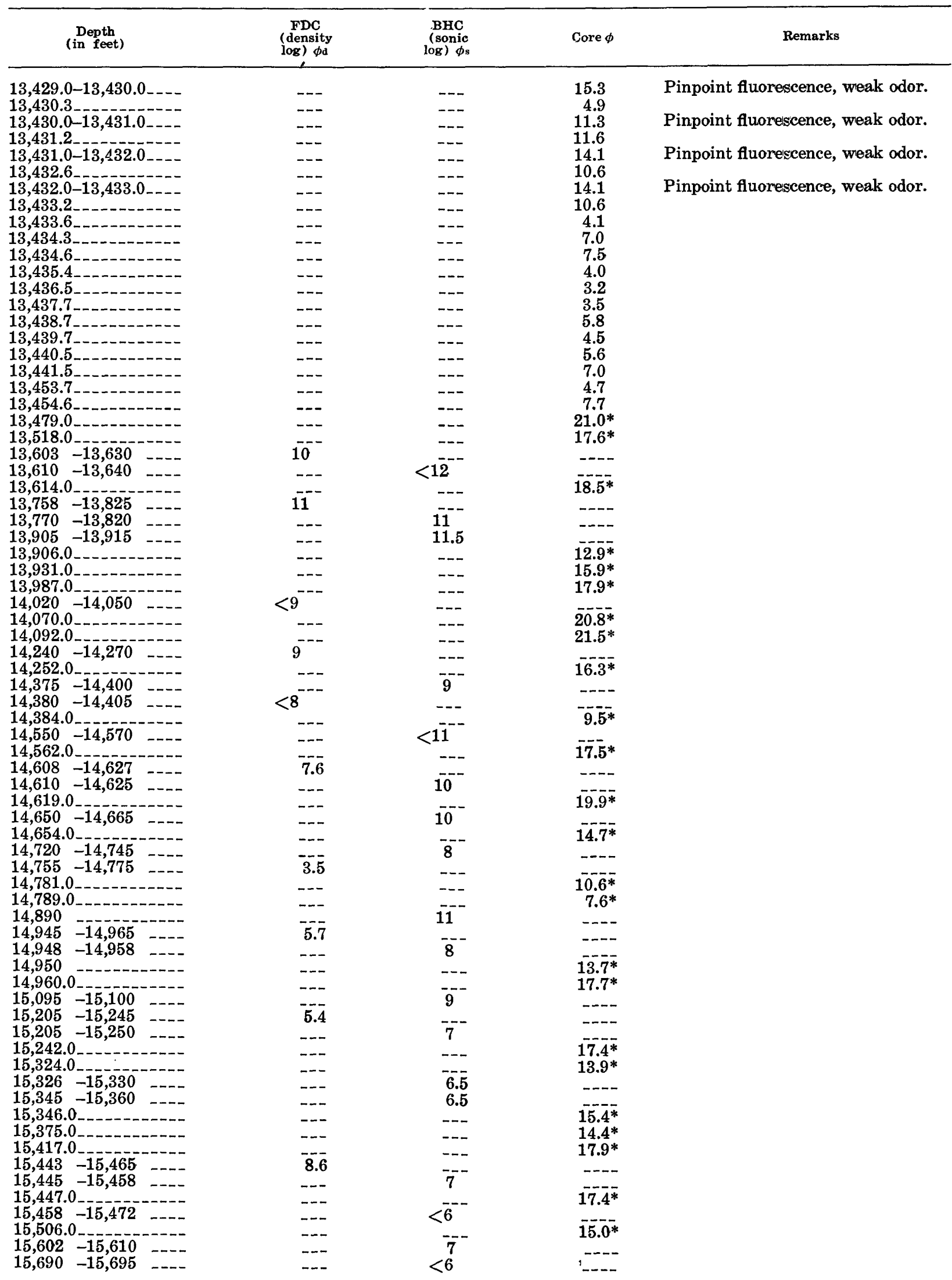


TABLE 6.-Comparison of porosity ( $\phi)$ values determined from electric log and core measurements on COST No. $B-2$ well samples-Continued

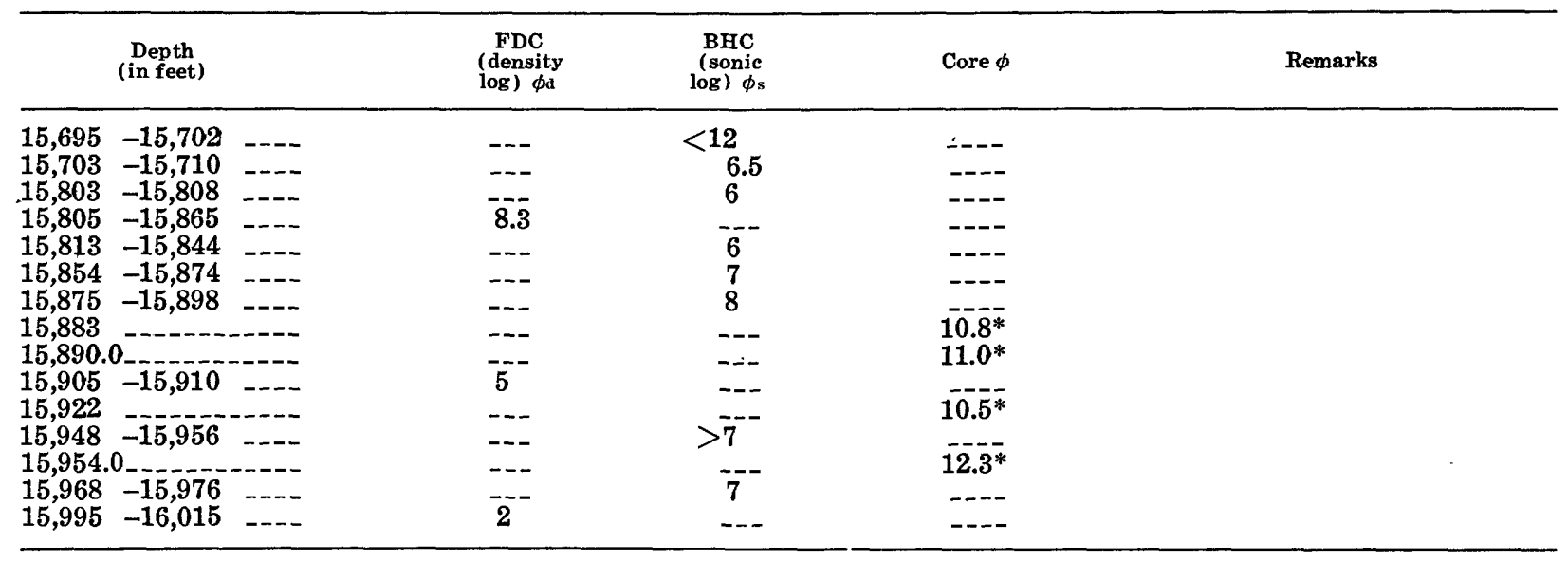




\title{
Sandstone Petrography
}

\author{
By P. A. Scholle
}

Sandstone chips were handpicked from rotary drill cuttings at 72 levels below 8,000 feet. Sandstone at these depths was judged likely to have the greatest overall reservoir potential and diagenetic complexity. One or more thin sections were cut for each interval, and from 4 to 10 chips representative of each interval were used. The sections were stained for potassium feldspars and were examined by means of a standard petrographic microscope. The results are shown in table 7.

The grain-size columns merely indicate the coanseness of the material examined petrographically and do not necessarily reflect the average grain size of sand in that interval. Coarser sand and gravel commonly would disaggregate into individual constituent grains, making examination of representative rock textures impossible. This petrographic analysis, therefore, emphasizes the finer grained and more lithified units in the section. Nevertheless, the overall changes in rock composition, fabric, and diagenesis described in the selected samples are probably representative of the whole section.

\section{COMPOSITION}

The entire section from 8,000 to 16,000 feet is feldspathic, and most sandstone is classed as subarkose. From 8,000 to about 12,800 feet, potassium feldspar (orthoclase and microcline) predominates, plagioclase is quite subordinate or absent. From about 12,800 feet to the bottom of the well, plagioclase feldspar increases in abundance and constitutes a significant rockforming element. The change in feldspar compasition most likely reflects changes in provenance rather than selective interstratal destruction of plagioclase because, whenever present, plagioclase is less altered than the potassium feldspar.
Rock fragments are present throughout the section although they are never a major rockforming element. Both sedimentary (shale and limestone) and metamorphic (slate, phyllite, schist, and gneiss) rock fragments were noted at many levels, and no particular evidence of progressive unroofing of source areas was seen.

Mast of the sediment from 8,000 to 9,740 feet contains glauconite of both pelletal and vermicular types. Some trace of glauconite is found to depths of about 10,100 feet; virtually none is present below that depth. The glauconite, in conjunction with the calcareous fossils and abundance of limestone noted in between 8,000 and 10,140 feet, indicates dominantly marine depositional conditions.

Sandstone throughout the 8,000-16,000-foot section is micaceous and pyritic, although at some intervals the pyrite has undergone partial alteration to iron oxide. Lignitic inclusions are present, especially near 10,000 feet, 11,000 feet, 12,600-13,000 feet, and 13,900-15,100 feet. Heavy minerals are present but were not specifically studied in this initial investigation. The occurrence of authigenic overgrowths on detrital tourmaline in the 15,260-foot sample indicates that marine incursions are present even in this part of the section because the boron of marine waters is needed to produce such overgrowths.

\section{DIAGENESIS AND CEMENTATION}

The loss of porosity as a function of burial depth in the COST No. B-2 well is noted in the section "Sandstone Porosities" and in direct laboratory measurements of petrophysical properties of the sidewall and conventional cores (Smith and others, 1976). The causes of this depth-related porosity loss are complex but are decipherable from petrographic analysis. 
TABLE 7.-Petrography of sandstone from the COST No. B-2 well

Depths given in feet and represent 30-foot sampling intervals from stated depth mon; $t=$ trace; $?=$ possible Grain size: $\mathbf{S}=$ Silt

$\mathrm{Fi}=$ Fine to very fine sand $\mathbf{M}=$ Medium sand

$\mathbf{C}=$ Coarse sand and grave

Constituents:

$\mathrm{Q}=$ Quartz
$\mathrm{K}=\mathrm{K}-$ Feldspar

$\mathbf{P}=$ Plagioclase

RF $=$ Rock fragments

GL = Glauconite

PY $=$ Pyrite
$\mathrm{MI}=$ Mica

LI = Lignite

Diagenesis

Fr=Fresh unaltered feldspar

Al=Altered (sericitized,

Co $=$ Compaction features

Or = Grain orientation

Cement

Qo = Quartz overgrowths

$\mathrm{CL}=$ Clay (authigenic)

$\mathrm{CA}=$ Calcite

$\mathrm{DO}=$ Dolomite

SI= Siderite

Rock name (Classification from Folk, 1968)

QA = Quartzarenite
FQA = Feldspathic quartzarenite

SA = Subarkose

A $=$ Arkose

Miscellaneous

$\mathbf{F}=$ Fossiliferous

$\mathrm{Ls}=$ Limestone

Oo $=$ Oolite

$\mathrm{Sc}=$ Sericite

$\mathrm{Chl}=$ Chlorite

MRF = Metamorphic rock fragments

SRF = Sedimentary rock fragments

CF $=$ Calcitized feldspar

PC $=$ Poikilitic calcite

To= Tourmaline overgrowths

\begin{tabular}{|c|c|c|c|c|c|c|c|c|c|c|c|c|c|c|c|c|c|c|c|c|c|c|c|}
\hline Depth & $\mathbf{S}$ & Grair & $\underset{\mathrm{M}}{\text { size }}$ & C & $\mathbf{Q}$ & $\mathbf{K}$ & $\mathbf{P}$ & $\begin{array}{l}\text { Co } \\
\text { RF }\end{array}$ & $\begin{array}{l}\text { astitu } \\
\text { GL }\end{array}$ & PY & MI & LI & Fr & $\begin{array}{l}\text { Diag } \\
\text { Al }\end{array}$ & $\begin{array}{l}\text { Cones } \\
\text { ron }\end{array}$ & is $\mathrm{Or}$ & Qo & CL & $\underset{\text { CA }}{\text { Cements }}$ & DO & SI & $\begin{array}{l}\text { Rock } \\
\text { name }\end{array}$ & $\begin{array}{c}\text { Mis- } \\
\text { cellaneous }\end{array}$ \\
\hline 8,030 & $\mathbf{x}$ & $\mathbf{x}$ & & & $\mathbf{x}$ & $\mathbf{x}$ & $\mathbf{x}$ & & $\mathbf{x}$ & & $\mathbf{x}$ & & $\mathbf{X}$ & & $\mathbf{x}$ & & & & $\mathbf{x x}$ & & & FQA-SA & F, Ls \\
\hline 8,210 & $\mathbf{X}$ & $\mathbf{X}$ & & & $\overline{\mathbf{X}}$ & $\bar{x}$ & & & $\mathbf{x}$ & $\mathbf{X}$ & & & & & & & & & $\overline{\mathbf{X X}}$ & & & FQA & F, Ls, PC \\
\hline 8,250 & $\mathrm{x}$ & $\bar{X}$ & & $\mathbf{X}$ & $\bar{x}$ & $\overline{\mathbf{X}}$ & $t$ & & $\bar{x}$ & $t$ & & & $\bar{X}$ & & & & & & $\mathrm{xx}$ & & & SA & F, Ls \\
\hline 8,290 & $\overline{\mathbf{x}}$ & & $\overline{\mathbf{X}}$ & $\bar{x}$ & $\mathrm{X}$ & $\mathbf{X}$ & & $\mathbf{X}$ & $x$ & & $\mathbf{X}$ & & & & $\overline{\mathbf{X}}$ & & & $\mathbf{x}$ & $\mathbf{x x}$ & & & FQA-SA & F, Ls, SRF \\
\hline 8,390 & & $\mathbf{X}$ & $\mathbf{X}$ & & $\mathbf{x}$ & $\mathbf{x}$ & & & & & $\mathbf{x}$ & & $\mathbf{X}$ & & $t$ & & & & $\mathbf{x x}$ & & & SA & F, Ls, PC \\
\hline 8,420 & $\mathbf{X}$ & & $\overline{\mathbf{X}}$ & & $\mathbf{x}$ & $x$ & & & $\overline{\mathbf{X}}$ & $\bar{X}$ & $x$ & & $\mathbf{x}$ & & & $\mathbf{X}$ & $t$ & $\bar{X}$ & $\mathbf{x}$ & & & FQA & F, Ls, PC \\
\hline 8,480 & $\bar{x}$ & $\mathbf{X}$ & & & $\mathbf{x}$ & $\mathbf{x}$ & & $\mathbf{X}$ & $\mathrm{x}$ & $t$ & $x$ & & & $?$ & & $\mathrm{x}$ & & & $\mathbf{x} \overline{\mathbf{X}}$ & & & SA-A & SRF, PC \\
\hline 8,510 & $\mathbf{X}$ & $\mathbf{X}$ & & & $\mathrm{x}$ & $\mathbf{x}$ & & & $\mathbf{x}$ & $\mathbf{X}$ & & & & & $\mathbf{X}$ & & $t$ & $t$ & $\mathbf{x}$ & & & SA & PC \\
\hline 8,570 & $\mathbf{X}$ & & $\mathbf{X}$ & & $\mathrm{X}$ & $\mathbf{x}$ & & & & $t$ & $t$ & & & & & & & & $\mathbf{x} \bar{x}$ & & & FQA-SA & Ls \\
\hline 8,700 & $\mathbf{x}$ & $\overline{\mathbf{X}}$ & & & $\bar{x}$ & $\bar{X}$ & & & & $\mathbf{X}$ & & & $\bar{X}$ & & & & & $\mathbf{X}$ & $\mathbf{x}$ & $\mathbf{X}$ & & QA-SA & Chl-Sc \\
\hline 8,780 & $\overline{\mathbf{x}}$ & $\mathrm{X}$ & & & $x$ & $\mathrm{x}$ & & $\mathbf{X}$ & & $x$ & & & & & & & $\mathrm{t}$ & $\mathrm{x}$ & $\mathbf{x}$ & & & FQA-SA & F, Ls, SRF \\
\hline 8,870 & $\mathbf{X}$ & & & & $\mathbf{X}$ & $t$ & & & $\bar{X}$ & $\bar{X}$ & $\bar{x}$ & $\bar{X}$ & & & $\overline{\mathbf{X}}$ & & & $\mathrm{x}$ & $\mathbf{x}$ & $?$ & & QA & F, Ls \\
\hline 8,980 & $\overline{\mathbf{X}}$ & & & & $\mathbf{x}$ & $\mathbf{x}$ & & & & & $\bar{x}$ & & & & $\bar{x}$ & & & $\mathrm{x}$ & $\mathbf{x}$ & $\bar{X}$ & $?$ & FQA & F, Ls \\
\hline 9,080 & $\overline{\mathbf{X}}$ & & & & $x$ & $x$ & & & $t$ & $\mathbf{X}$ & & & & & $\mathrm{x}$ & $\mathbf{X}$ & & $?$ & $\mathbf{x}$ & & & SA-Mst & F \\
\hline 9,170 & & $\mathbf{X}$ & $\mathbf{X}$ & & $x$ & $\mathbf{x}$ & & $\bar{X}$ & $t$ & $\bar{x}$ & & & $\mathbf{X}$ & & & & & $?$ & $\mathbf{x} \bar{x}$ & & & $\mathbf{S A - A}$ & F, Ls, MRF \\
\hline 9,260 & $\bar{X}$ & $\bar{X}$ & $\mathrm{x}$ & & $x$ & $\mathbf{x}$ & & & $\mathbf{x}$ & $\mathbf{x} \bar{x}$ & & & $\mathbf{X}$ & & & & & & $\mathbf{x x}$ & & & $\mathbf{S A}-\mathbf{A}$ & F, Ls \\
\hline 9,380 & $\mathbf{X}$ & $\mathrm{X}$ & & & $\mathbf{x}$ & $\mathbf{X}$ & & $\overline{\mathbf{X}}$ & & $\mathrm{x}$ & & & $\mathbf{x}$ & & $\mathbf{X}$ & & & $\bar{x}$ & $\mathbf{x}$ & & $\mathrm{X}$ & SA & $\begin{array}{l}\text { F, PC, MRF } \\
\text { SRF }\end{array}$ \\
\hline 9,410 & $\mathbf{x}$ & $\overline{\mathbf{X}}$ & & & $\bar{X}$ & $\mathbf{X}$ & $t$ & $\mathbf{X}$ & & $\overline{\mathbf{X}}$ & $\overline{\mathbf{X}}$ & & $\mathbf{X}$ & & & & & $\overline{\mathbf{X}}$ & $\mathbf{X X}$ & $?$ & $\bar{X}$ & SA & $\underset{\text { PC }}{\text { SRF, MRF, }}$ \\
\hline 9,510 & $\mathbf{X}$ & $\overline{\mathbf{X}}$ & & & $\mathbf{X}$ & $\bar{X}$ & $\mathbf{t}$ & $\mathbf{X}$ & $\mathbf{X}$ & $t$ & $\bar{X}$ & & & & $\overline{\mathbf{X}}$ & $\mathbf{X}$ & $\mathbf{t}$ & $\bar{X}$ & & & & FQA & \\
\hline 9,620 & $\overline{\mathbf{X}}$ & $\bar{x}$ & & & $\mathbf{x}$ & $\mathbf{x}$ & $t$ & $\mathbf{X}$ & $t$ & $\mathbf{X}$ & & $t$ & & & $x$ & & & $\mathbf{x}$ & $\mathbf{X}$ & & & SA-A & PC, Ls, SRF \\
\hline 9,710 & $\mathbf{X}$ & $\bar{x}$ & & & $\bar{x}$ & $\mathrm{x}$ & $t$ & & $t$ & $t$ & & $\overline{\mathbf{X}}$ & $\mathbf{X}$ & & $\mathrm{x}$ & & & $\mathbf{x}$ & $\mathrm{x}$ & & & SA & F, Ls \\
\hline 9,740 & & $\mathbf{x}$ & $\mathbf{X}$ & & $\mathrm{x}$ & $\bar{x}$ & 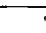 & & $x$ & $\bar{X}$ & $\bar{X}$ & & & & $\mathrm{x}$ & & & & $\mathbf{x} \overline{\mathbf{x}}$ & & & SA & F, Ls \\
\hline 9,860 & $\bar{X}$ & $\bar{X}$ & & & $x$ & $x$ & $\mathbf{X}$ & & & $\bar{X}$ & $x$ & & & & $\bar{x}$ & & & & $\mathbf{x} \mathbf{x}$ & & & SA-A & $\mathbf{F}$ \\
\hline 9,950 & $\bar{x}$ & $\overline{\mathbf{x}}$ & $\bar{X}$ & & $\mathbf{x}$ & $\mathbf{x}$ & & $\mathbf{X}$ & & $\bar{x}$ & $\mathbf{x}$ & & $\overline{\mathbf{X}}$ & & $x$ & $\mathbf{X}$ & & $\overline{\mathbf{X}}$ & $\mathbf{x} \bar{x}$ & & & FQA-SA & $\begin{array}{l}\text { F, Is, Ser, } \\
\text { MRF }\end{array}$ \\
\hline$\overline{10,010}$ & $\mathbf{x}$ & $\overline{\mathbf{X}}$ & & & $\overline{\mathbf{X}}$ & $\mathbf{X}$ & $t$ & $\mathbf{X}$ & & $\mathbf{t}$ & $\mathbf{x}$ & & $\bar{x}$ & & $\mathbf{X}$ & $\overline{\mathbf{X}}$ & & $\mathbf{X}$ & $\overline{\mathbf{X X}}$ & & & $\mathbf{S A - A}$ & $\begin{array}{c}\text { Ls, Sc, PC, } \\
\text { SRF }\end{array}$ \\
\hline$\overline{10,070}$ & $\overline{\mathbf{x}}$ & $\bar{x}$ & & $\mathbf{X}$ & $\overline{\mathbf{x}}$ & $\mathbf{X}$ & & & $\bar{X}$ & $\bar{x}$ & $\mathbf{X}$ & $\mathbf{x}$ & & & & $\bar{X}$ & & & & & & QA-SA & Ls, F \\
\hline 10,140 & $\overline{\mathbf{X}}$ & & & & $\bar{x}$ & $\mathbf{x}$ & & & & & $\overline{\mathbf{X}}$ & $x$ & & & $\mathbf{X}$ & & $t$ & $\mathbf{X}$ & $\mathbf{X}$ & & $?$ & SA-Mst & Ls \\
\hline 10,330 & $\mathbf{X}$ & & & & $\mathbf{x}$ & $\mathbf{x}$ & $?$ & & & $\bar{X}$ & $\bar{x}$ & & & & $\mathbf{x}$ & & & $\mathrm{x}$ & $\mathbf{x}$ & & $\mathbf{x}$ & SA-QA & \\
\hline 10,420 & $\mathbf{x}$ & & & & $\mathrm{x}$ & $\bar{X}$ & & & & $\mathbf{x}$ & $\bar{x}$ & $\mathbf{x}$ & & & $x$ & & & & & & & SA-Mst & \\
\hline 11,320 & $\mathbf{x}$ & $\mathbf{X}$ & & & $\mathrm{x}$ & $\mathbf{X}$ & & & & $\bar{X}$ & $\bar{x}$ & $\bar{x}$ & $\mathbf{X}$ & & & & & $\mathbf{X}$ & $\bar{X}$ & & & SA-Mst & F \\
\hline$\overline{11,530}$ & $x$ & $x$ & & & $\mathbf{x}$ & $\mathbf{x}$ & & & & $\mathrm{x}$ & $\mathbf{x}$ & & $\mathrm{x}$ & & & & & $\mathbf{t}$ & $\mathbf{x} \bar{x}$ & & & SA-QA & \\
\hline 11,620 & & $\mathbf{x}$ & $\mathbf{X}$ & & $\mathbf{X}$ & $\overline{\mathbf{X}}$ & & $t$ & & & & & $\mathbf{x}$ & & & & & $t$ & $\mathbf{X}$ & $t$ & $\mathbf{t}$ & A-SA & PC, F, Oo \\
\hline 11,740 & & $\mathbf{x}$ & $\mathbf{x}$ & & $\mathbf{X}$ & $\mathrm{X}$ & $t$ & & & & $\bar{X}$ & & & & & & & $\mathrm{X}$ & $\bar{x}$ & & & SA & \\
\hline 11,830 & $\mathbf{X}$ & $\mathrm{x}$ & & & $x$ & $\bar{x}$ & & & & $\mathbf{X}$ & 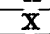 & & & & & & $\bar{X}$ & $\bar{X}$ & $\mathbf{X}$ & & & FQA & \\
\hline 11,920 & $\mathbf{x}$ & $\mathbf{x}$ & & & $\mathbf{x}$ & $\bar{X}$ & & & & & $\mathbf{x}$ & & & & $\mathbf{X}$ & & $t$ & $\bar{x}$ & $\bar{X}$ & & & SA & \\
\hline 12,000 & $\overline{\mathbf{x}}$ & $\bar{x}$ & & & $\bar{x}$ & $\mathbf{x}$ & & $\overline{\mathbf{x}}$ & & $\overline{\mathbf{X}}$ & $\mathbf{x}$ & & & & $\mathbf{x}$ & & & $\mathrm{X}$ & $\mathbf{X X}$ & & & A-SA & $\begin{array}{c}\text { Oo, F, Ls } \\
\text { SRF }\end{array}$ \\
\hline 12,130 & & $\mathbf{X}$ & & & $\mathrm{X}$ & $\bar{X}$ & & & & & $\bar{x}$ & & $\overline{\mathbf{X}}$ & & $\mathbf{X}$ & & & $\mathbf{t}$ & & & & SA & PC, SRF \\
\hline 12,250 & $\bar{X}$ & $\bar{x}$ & & & $\mathbf{X}$ & $\mathbf{x}$ & & $\mathbf{X}$ & & $\mathbf{X}$ & $\mathbf{x}$ & & & & $x$ & $\overline{\mathbf{X}}$ & $\mathbf{X}$ & $\mathbf{X}$ & & & & SA-QA & SRF \\
\hline 12,340 & $\mathbf{X}$ & $\bar{X}$ & & & $\mathbf{x}$ & $\bar{x}$ & & $\mathbf{x}$ & & $\mathbf{x}$ & & & $\bar{X}$ & & $\mathbf{x}$ & & & $t$ & $\bar{X}$ & & & QA-SA & F, PC, SRF \\
\hline 12,600 & $\mathbf{X}$ & $\overline{\mathbf{x}}$ & & & $\mathbf{x}$ & $t$ & & $x$ & & & $\mathbf{x}$ & $\overline{\mathbf{X}}$ & & $\mathbf{X}$ & $\mathbf{x}$ & & $\mathbf{t}$ & $\mathbf{X}$ & $\overline{\mathbf{x}}$ & & $t$ & QA & SRF, Sc \\
\hline 12,740 & & $\mathbf{x}$ & & & $\mathbf{x}$ & $\mathbf{x}$ & & & & $\overline{\mathbf{X}}$ & $\mathbf{x}$ & & $\bar{x}$ & & & & & & $\mathbf{x}$ & & & SA-A & PC, $\mathrm{Oo}, \overline{\mathrm{F}}$ \\
\hline 12,830 & & $\mathrm{x}$ & $\bar{x}$ & & $\mathrm{x}$ & $\mathbf{x}$ & $t$ & $\mathbf{x}$ & & $\mathbf{x}$ & & & & $t$ & & & & $\mathbf{t}$ & $\mathbf{X X}$ & & $\overline{\mathbf{x}}$ & SA-QA & PC, SRF, \\
\hline$\overline{12,980}$ & & $\mathbf{X}$ & & & $\mathbf{X}$ & $\bar{x}$ & $\mathbf{X}$ & $\mathbf{X}$ & & & $\bar{x}$ & $\overline{\mathbf{X}}$ & & $t$ & $\overline{\mathbf{X}}$ & & $\mathbf{t}$ & & $\mathbf{X}$ & & & $\overline{\mathbf{Q A}-\mathbf{S A}}$ & $\begin{array}{c}\text { SRF, MRF, } \\
\text { Ls }\end{array}$ \\
\hline 13,100 & $\bar{X}$ & $\mathrm{x}$ & $\mathbf{X}$ & & $\mathbf{X}$ & $\overline{\mathbf{x}}$ & $\mathrm{t}$ & $\mathbf{X}$ & & $\mathbf{t}$ & $\overline{\mathbf{x}}$ & & & & $\mathbf{X}$ & & $\overline{\mathbf{X}}$ & & $\mathbf{X}$ & $?$ & $\mathbf{X}$ & SA-QA & SRF, Ls \\
\hline 13,220 & & $\mathbf{x}$ & $\overline{\mathbf{x}}$ & & $\mathbf{X}$ & $\bar{x}$ & $\bar{x}$ & & & $t$ & & & & $\mathbf{t}$ & $\mathbf{x}$ & & $\mathbf{x}$ & $\bar{x}$ & $\mathbf{X}$ & & & SA & \\
\hline 13,370 & $\mathbf{X}$ & $\mathbf{x}$ & & & $\bar{x}$ & $\bar{x}$ & $x$ & $\mathbf{t}$ & & $\bar{x}$ & $\overline{\mathbf{X}}$ & & & $\mathbf{x}$ & $\mathbf{x}$ & & & $\mathbf{X}$ & & & & A-SA & SRF, Sc \\
\hline 13,570 & $\mathbf{X}$ & $\mathbf{x}$ & & & $\mathbf{X}$ & $\mathbf{x}$ & $\mathbf{x}$ & & & & $\mathbf{x}$ & & & $\mathbf{x}$ & $\bar{x}$ & & $t$ & $\mathbf{X X}$ & & & $\overline{\mathbf{X}}$ & SA & Sc \\
\hline 13,660 & & $\mathbf{x}$ & $\mathbf{X}$ & & $x$ & $x$ & $t$ & $\overline{\mathbf{x}}$ & & $\mathbf{X}$ & $\mathbf{x}$ & & & $\overline{\mathbf{X}}$ & & & $\mathbf{X}$ & $\bar{x}$ & $t$ & & & FQA-SA & SRF, Sc \\
\hline 13,810 & & $\mathrm{x}$ & $x$ & & $\mathbf{x}$ & $\mathbf{x}$ & $\mathbf{x}$ & $\mathrm{x}$ & & & $\mathrm{x}$ & & & $\mathbf{x}$ & $\bar{x}$ & & $\overline{\mathbf{X}}$ & $\bar{x}$ & $\mathrm{t}$ & & & A-SA & Se \\
\hline 13,910 & & $\mathbf{x}$ & $\mathbf{x}$ & & $\bar{x}$ & $\mathbf{x}$ & $\mathrm{x}$ & $\mathbf{x}$ & & $\bar{x}$ & & $\mathbf{X}$ & $\bar{X}$ & & $\mathbf{x}$ & & $\overline{\mathbf{x}}$ & $\overline{\mathbf{X}}$ & & & & SA-A & SRF \\
\hline 14,050 & & $\mathbf{x}$ & $\mathbf{x}$ & $\mathbf{X}$ & $\mathbf{x}$ & $\mathbf{x}$ & $\mathbf{x}$ & $\mathbf{x}$ & & $\mathbf{x}$ & & & & $\mathrm{X}$ & & & $\mathbf{X}$ & $\mathbf{X}$ & $t$ & & & SA-A & SRF \\
\hline 14,140 & & $\mathrm{x}$ & $\mathbf{x}$ & & $\mathbf{x}$ & $x$ & $x$ & $t$ & & & $\bar{x}$ & $\mathbf{X}$ & & $\bar{x}$ & $x$ & & $\mathbf{X}$ & $\mathbf{X X}$ & $\mathbf{X}$ & & & A-SA & CF, SRF \\
\hline 14,210 & & & $\mathbf{x}$ & $x$ & $x$ & $\mathbf{x}$ & $\mathbf{x}$ & $\mathbf{X}$ & & & $\mathrm{x}$ & $x$ & & $\mathbf{x}$ & & & $\mathbf{X}$ & $\mathbf{x}$ & $\mathbf{X}$ & & & A-QA & \\
\hline 14,270 & & & $\mathbf{x}$ & $\mathbf{x}$ & $\mathbf{x}$ & $\mathbf{x}$ & $\mathrm{x}$ & & & & $\bar{x}$ & $\bar{x}$ & & $\mathbf{x}$ & & & $t$ & $\mathbf{x}$ & $\overline{\mathbf{X X}}$ & & & SA & PC, CF \\
\hline 14,300 & & $\mathbf{x}$ & $\mathbf{x}$ & $\mathbf{x}$ & $\mathbf{x}$ & $\mathbf{x}$ & $\mathbf{x}$ & & & $\mathbf{x}$ & & & & $\mathbf{x}$ & & & $\mathbf{X}$ & $\mathbf{x}$ & $t$ & & & $\overline{\mathbf{S A}-\mathbf{A}}$ & \\
\hline 14,420 & $\bar{x}$ & $\mathbf{x}$ & $\mathbf{x}$ & & $\mathbf{x}$ & $\mathbf{x}$ & & & & & $\bar{x}$ & & & $\mathbf{t}$ & & & $\bar{x}$ & $\bar{x}$ & $\mathbf{X}$ & & & QA-SA & MRF+SRF \\
\hline 14,570 & & $\mathbf{X}$ & $\mathbf{x}$ & & $x$ & $\bar{x}$ & $\mathbf{t}$ & & & & $\mathrm{x}$ & $\mathbf{X}$ & $\bar{X}$ & & & $\bar{x}$ & $\mathbf{x}$ & $\mathbf{X X}$ & & & & SA & \\
\hline
\end{tabular}


TABLE 7.-Petrography of sandstone from the COST No. B-2 well-Continued

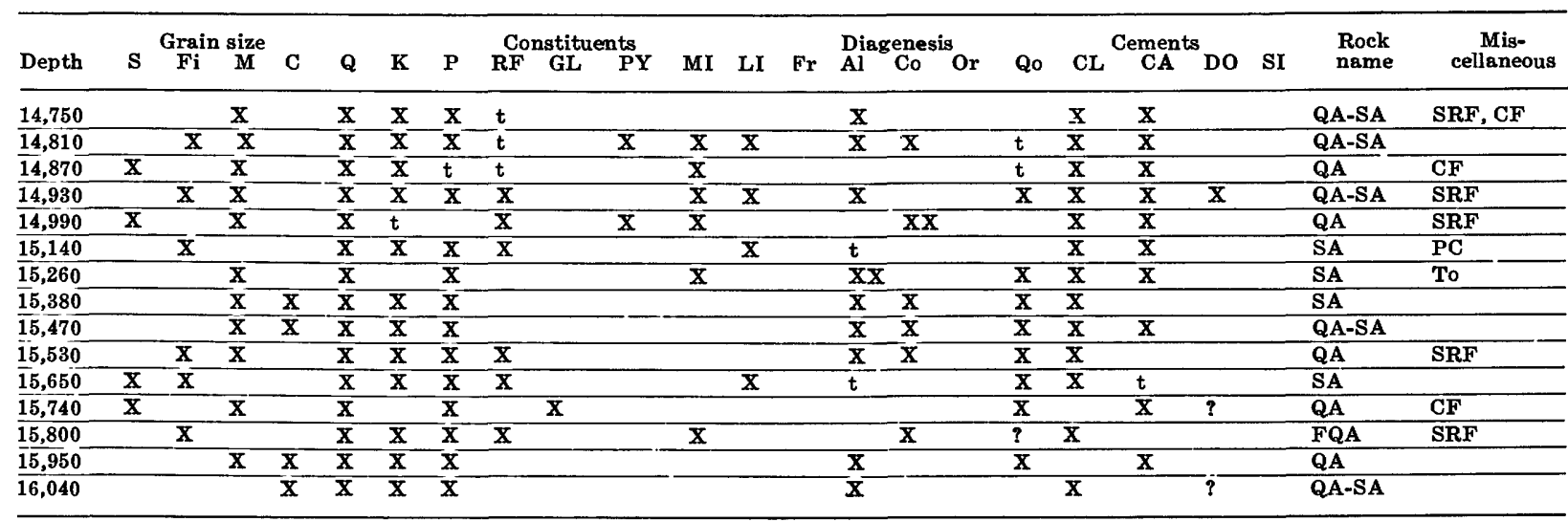

In the depth interval examined, compaction effects are significant. Crushing of relatively soft grains (such as glauconite or mica), reorientation of elongate grains, and shattering or twinning of brittle minerals are commonly noted. Grain interpenetration through pressure-solution embayment was less commonly found. Thus, mechanical compaction resulting from increased subsurface lithostatic pressures has played an important role in porosity loss.

Perhaps even more important, however, are the chemical effects of mineral alteration and cement precipitation. Starting at 12,600 feet or earlier, alteration of feldspar (both potassium feldspar and plagioclase) becomes progressively more important as burial depth increases. This alteration takes the form of sericitization, kaolinization, vacuolization, or calcite replacement and varies from one unit to the next. However, the general increase in feldspar alteration with depth can be correlated with the increasing.importance of authigenic clay minerals and quartz overgrowths as cementing agents. In many of the samples from 13,000 feet downward, kaolinite, illite, sericite, or authigenic silica produce almost complete obliteration of primary porosity.

Calcite is also extremely important as a cementing agent. In the depth range from 8,000 to 13,000 feet, calcite is clearly the major cement. Below 13,000 feet it remains important but begins to be overshadowed by clay and silica cement. The abundance of calcareous fossils, limestone, and limestone clasts in the parts of the section containing the greatest amounts of calcite cement indicates that at least some of the cement may be derived by in situ dissolution of calcareous material and reprecipitation as cement. The common poikilitic textures of the calcite cement indicate that the presence of carbonate skeletal or rock fragments is a factor in the nucleation of calcite cement.

Other calcareous cement, including dolomite, ankerite, and siderite, is occasionally observed but is rarely of major importance. The only zones containing significant siderite cement are at 9,300-9,500 feet, 10,330 feet, and between 12,800 and 13,600 feet.

\section{CONGLUSIONS}

The predominance of arkosic sediments throughout the section coupled with their burial-related decomposition leads to significant porosity loss in the deeper part of the section in the COST No. B-2 well. In addition, zones containing significant marine fossils, limestone, or associated calcareous shale have the greatest amounts of carbonate cement. Prospects for improved porosity at equivalent or greater depths at other sites are relatively unfavorable unless a significantly less arkosic section is found or unless some other factor such as geopressuring or oil saturation has retarded the breakdown of feldspar. 


\title{
Foraminiferal Biostratigraphy
}

\author{
By C. W. Poag
}

Upper Tertiary sediments in the COST No. B-2 well were deposited in shallow marine or nearshore subaerial environments. During the early Tertiary, however, especially during the Eocene, carbonate rocks were deposited at Continental Slope water depths. Most of the Upper Cretaceous strata are fully marine, containing diagnostic planktonic and benthic fossils that indicate shelf conditions of deposition. In contrast, during the Early Cretaceous, many of the beds accumulated under subaerial conditions, as shown by the lack of marine fossils and the abundance of terrestrial palynomorphs. The age of the oldest strata penetrated was not established in this foraminiferal study.

The following discussion of foraminifers is based on preliminary analyses of samples from rotary cuttings taken at widely spaced intervals, ranging from 100 to 500 feet. The conclusions are tentative and are subject to revision upon further detailed study.

\section{PLEISTOCENE}

The youngest sample examined came from 610 feet and contained an abundant benthic fauna of Pleistocene species, most of which have living representatives off New Jersey today. Diagnostic forms include Elphidium orbiculare, E. clavatum, Cibicidoides lobatulus, Epistominella vitrea, Nonionella atlantica, and Bulimina aculeata. Similar assemblages are present to 790 feet and contain scattered occurrences of reworked Eocene species.

\section{PLIOCENE}

At 880 feet, the first significant change in species composition occurs. Particularly diagnostic is Buliminella gracilis, which is abundant in the Miocene and extends in fewer numbers into the Pliocene. Its sparsity and its association with a meager planktonic fauna of
Globigerina bulloides and Globigerinoides trilobus appear to indicate a Pliocene age for this sample.

\section{MIOCENE}

The first examined sample containing significant numbers of typical Miocene species was at 1,090 feet. Buliminella gracilis is abundant and is accompanied by Lenticulina spinosa, Florilus pizzarensis, and abundant specimens of Uvigerina sp. and Cibicidoides sp. No diagnostic planktonic species are present. From 1,090 feet to 1,480 feet, similar but sparser faunas dominated by $B$. gracilis are present.

At 1,510 feet is the first indication of middle Miocene age. Turborotalia siakensis, which becomes extinct in Zone N. 14 (Blow, 1969), is rare in this sample. Buliminella gracilis is still the predominant taxon. The Miocene section above 1,510 feet, therefore, is placed in the upper Miocene.

Similar shallow-water faunas dominated by $B$. gracilis, which is often the only taxon present, are present throughout the interval between 1,510 feet and 2,710 feet. Turborotalia siakensis occurs sparsely in scattered samples throughout this interval. At 2,710 feet, the foraminiferal association is the same, but diatoms begin to appear in significant numbers. At 2,800 feet, among an abundance of diatoms, T. peripheroacuta appears, indicating a middle Miocene age, no younger than Zone N. 12 and no older than N. 10. At 2,890 feet, diatoms are still abundant, along with $B$. gracilis. Occasional specimens of $T$. siakensis and $T$. peripheroacuta are found and radiolarians are present occasionally.

The next major faunal change takes place at 3,880 feet, where $B$. gracilis is no longer predominant, and where Globigerinita ciperoensis and Turborotalia continuosa indicate an early Miocene age, no younger than Zone N. 6. 


\section{EOCENE}

At 4,200 feet, the first rich late Eocene fauna is found. Typical planktonic species include Turborotalia cocoaensis, T. cerroazulensis, T. pomeroli, T. ampliaperatura, Globigerinatheka index, Hantkenina alabamensis, and Pseudohastigerina micra. The rich benthic fauna includes Bulimina jacksonensis, Sigmoidella plummerae, Anomalina alazanensis, and Lenticulina subpapillosa. This assemblage is no younger than Zone P. 17 (Blow, 1969).

Middle Eocene species are present in the sample at 4,500 feet. Diagnostic forms include Acarinina densa, Truncorotaloides topilensis, Morozovella aragonensis, and Acarinina pentacamerata. These forms represent Zones P. 11 to P. 8.

The sample at 4,800 feet is of early Eocene age, containing Planorotalites chapmani, Pseudohastigerina wilcoxensis, Subbotina frontosa, and $S$. inaequispira.

\section{PALEOCENE}

At 5,110 feet, the presence of Acarinina uncinata, A. soldadoensis, Morozovella velascoensis, $M$. kolchidica, and $M$. aequa suggests a late Paleocene age, probably Zone P. 5. A few reworked Cretaceous species also begin to appear.

An unusual association of shallow-water agglutinated foraminifers, abundant plant fragments, and gypsum crystals at 5,300 feet cannot be dated by means of foraminifers; it suggests restricted environmental conditions that might exist in a lagoon or estuary.

\section{CRETACEOUS}

The first sample examined containing abundant Late Cretaceous species came from 5,600 feet. Diagnostic forms include Globotruncana fornicata, G. elevata, G. arca, Rugoglobigerina rugosa, Cibicidoides micheliniana, Planulina texana, Kyphopyxa christneri, Lenticulina pondi, and Pseudogaudryinella capitosa. This assemblage appears to be of Campanian or Early Maestrichtian Age. At 5,900 feet, the first Bolivinoides was observed, appearing to be $B$. miliaris, a late Campanian and early Maestrichtian species.

From 5,900 feet to 7,100 feet, the faunas appear to be largely cavings from younger Tertiary beds. Few, if any, indigenous Cretaceous species are present. At 7,100 feet, however, the presence of Globotruncana helvetica, and $G$. imbricata indicates sediments of Turonian Age. $G$. helvetica is still abundant at 7,400 feet.

At 7,700 feet, Cenomanian species are present. They include Rotalipora cushmani, Praeglobotruncana stephani, and $P$. cf. turbinata.

The Lower Cretaceous strata (Albian) begin at approximately 8,200 feet, marked by Favusella washitensis.

Below this point, the foraminiferal faunas are sparse and appear to be primarily composed of cavings from the younger beds. Few, if any, indigenous specimens occur.

\section{PALEOECOLOGY}

During the Early Cretaceous, the B-2 area apparently was a coastal region in which primarily continental deposits accumulated, as shown by the sparsity of marine fossils and the abundance of terrestrial plant remains, coal beds, and nonmarine sand and clay. At some time during the Albian, however, a shallow marine sea occupied the B-2 site, and deposited marine microfossils and nannofossils. The generally shallow marine environment persisted throughout most of the Late Cretaceous. The notable exceptions are represented by the sediments from approximately 7,100 feet to 6,200 feet, in which no marine fossils are present, and the sample at 5,300 feet, which may have accumulated in estuarine conditions.

During the Paleocene, shallow shelf conditions again were predominant. During the Eocene, however, the water depth increased to the equivalent of that on today's Continental Slope; the richest faunal remains in the B-2 well accumulated during this period.

During the Miocene and Pliocene, the environment fluctuated frequently from inner- to outer-shelf depths, and occasionally subaerial erosion took place marked by oxidation and abrasion of fossil remains. The rich diatom floras of the middle Miocene reflect a specialized environment of high nutrient content, brought about, perhaps, by cool waters upwelling along the shelf edge. The Late Miocene faunas are of very low diversity and are found amidst sandy beds in what appear to have been prograding deltas. The Pleistocene was a time when coarse glacial sand and gravel accumulated in shallow marine waters and in terrestrial coastal-plain environments. No obvious cyclicity of glacial-interglacial sequences was noted during the preliminary analysis. 


\title{
Nannofossil Biostratigraphy
}

\author{
By P. C. Valentine
}

This preliminary study is based on an analysis of samples from rotary cuttings spaced at 100-foot and 300-foot intervals. Discrete rock fragments representing each of the major lithologic units present in a single sample were selected and processed. The oldest assemblage identified in a sample was considered to indicate the age of the strata at that level. As many as five subsamples were studied from a single 10- to 30-foot-interval sample. Settling techniques were used to concentrate the sample for study of the calcareous nannofossils. Zonal data are summarized in table 8.

\section{PLEISTOCENE THROUGH MIOCENE ( $\cong 700$ FEET $T O \cong 3,730$ FEET)}

Strata of Pleistocene through Miocene age are present to a depth of approximately 3,800 feet. The highest sample available for study was from $\mathbf{7 0 0}$ to $\mathbf{7 3 0}$ feet, in which calcareous nannofossils are rare and tentatively indicate a Pleistocene age. Samples from 790 feet through 3,520 feet are essentially barren. Diatoms, however, are particularly abundant from 2,890 feet through 3,520 feet; this interval has been dated as middle Miocene on the basis of a study of the foraminifers. Recent studies have shown that this sequence of mainly shallow-water terrigenous clastic sediment is characteristic of this age interval elsewhere on the Continental Shelf north of Cape Hatteras.

Calcareous sediments of early Miocene age are found from 3,580 feet to 3,730 feet. Two samples $(3,580-3,610$ feet and $3,700-3,730$ feet) were investigated from this interval and found to contain the following assemblage, which is representative of the upper part of the Triquetrorhabdulus carinatus Zone of Bukry (1973, 1975) : Coccolithus eopelagicus, C. pelagicus, Coronocyclus nitescens, Cyclicargolithus abisectus, C. floridanus (abundant),
Discoaster adamanteus, $D$. deflandrei, $D$. druggi, D. saundersi (common), D. variabilis, Discolithina spp., Helicosphaera euphratis, $H$. intermedia, $H$. recta, Reticulofenestra cf. $R$. scissurus of Bramlette and Wilcoxon (1967), Sphenolithus capricornutus, S. dissimilis, S. moriformis, and Triquetrorhabdulus carinatus.

\section{OLIGOCENE \\ ( $\cong 3,790$ FEET TO $\cong 4,050$ FEET)}

Calcareous strata of late Oligocene age are found in the interval bounded by samples from 3,790 to 3,820 feet and 4,030 to 4,050 feet. These sediments contain the following assemblage, characteristic of the Sphenolithus ciperoensis Zone of Bukry (1973, 1975): Chiasmolithus altus, Coccolithus eopelagicus, C. pelagicus, Cyclicargolithus abisectus (abundant), C. floridanus (abundant), Dictyococcites bisectus, Discoaster deflandrei, D. rufus, D. saundersi, Discolithina spp., Helicosphaera bramlettei, $H$. euphratis, $H$. intermedia, $H$. wilcoxoni, Reticulofenestra cf. $R$. scissurus of Bramlette and Wilcoxon (1967), Sphenolithus dissimilis, S. moriformis, S. ciperoensis, and Zygrhablithus bijugatus.

\section{OLIGOCENE THROUGH EOCENE ( $\cong 4,080$ FEET TO $\cong 4,320$ FEET)}

Calcareous strata of earliest Oligocene to latest Eocene age are present in the interval bounded by samples from 4,080 to 4,110 feet and 4,290 to 4,320 feet. These sediments contain the following assemblage, indicative of the Coccolithus subdistichus and Isthmolithus recurvus Subzones of Bukry $(1973,1975)$ : Chiasmolithus oamaruensis, Coccolithus eopelagicus, C. pelagicus, C. sarsiae of Bybell (1975), C. subdistichus (common), Cyclicargolithus floridanus, Cyclococcolithina formosa, C. kingii,. Dictyococcites bisectus, D. scrippsae, Discoli- 


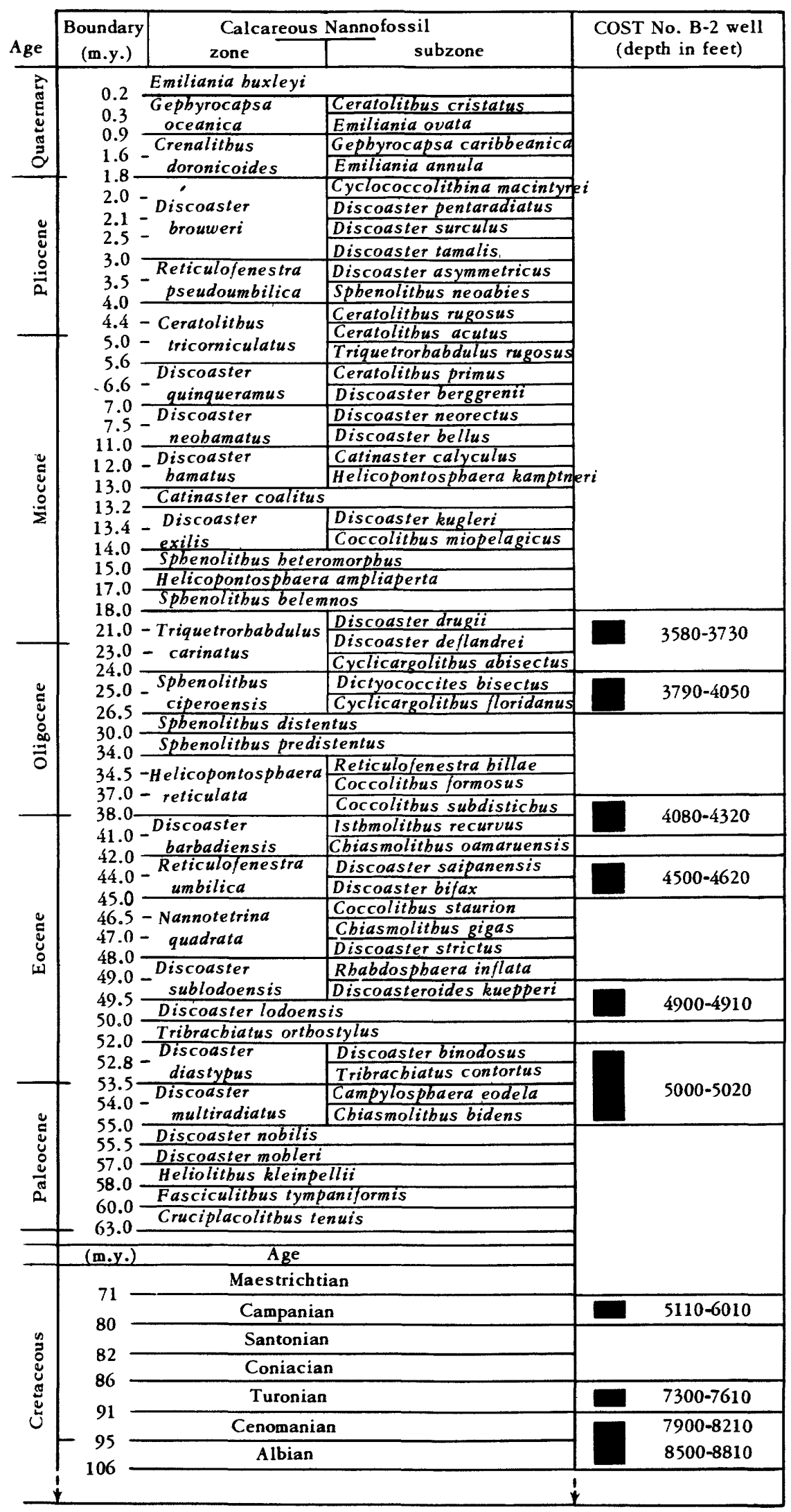


$\triangle$ TABLE 8.-Preliminary age determinations of COST No. B-2 samples on the basis of calcareous nannofossils [Samples below 8,810 feet were barren. Depths are in feet below Kelly Bushing. Calcareous nannofossil zones and subzones and estimated time relations are taken from Bukry (1975, fig. 3 and table 2). Black bars indicate range of determinations for given sample depths.]

thina spp., Helicosphaera compacta, Isthmolithus recurvus, Lanternithus minutus, Neococcolithes dubius, Reticulofenestra hillae, $R$. reticulata, $R$. cf. $R$. scissurus of Bramlette and Wilcoxon (1967), $R$. umbilica, Transversopontis obliquipons, and T. zigzag.

\section{EOCENE \\ (@4,500 FEET TO $\cong 4,910$ FEET $)$}

Two samples (from 4,500 to 4,530 ft and 4,590 to $4,620 \mathrm{ft}$ ) contain calcareous sediments of middle to late Eocene age. The assemblage identified in these samples is characteristic of the Reticulofenestra umbilica Zone of Bukry $(1973,1975)$ : Chiasmolithus grandis, C. solitus, C. titus, Coccolithus eopelagicus, C. pelagicus, Cyclicargolithus floridanus, Cyclococcolithina formosa, Discoaster barbadiensis, Helicosphaera lophota, H. seminulum, Neococcolithes dubius, Reticulofenestra hillae, $R$. reticulata, $R$. samodurovi, $R$. umbilica, Sphenolithus moriformis, and Zygrhablithus bijugatus.

The sample from 4,900 to 4,910 feet, also calcareous, yielded an assemblage of early to middle Eocene age; it is placed in the Discoaster lodensis Zone and Discoasteroides kuepperi Subzone of Bukry $(1973,1975)$ : Blackites creber, Campylosphaera dela, Chiasmolithus grandis, Coccolithus crassus (abundant), C. pelagicus, Cyclococcolithina kingii, Discoaster lodoensis, D. binodosus, Discoasteroides kuepperi, Helicosphaera seminulum, Lophodolithus mochlophorus, L. nascens, Markalius inversus, Marthasterites tribrachiatus, Neococcolithes dubius, N. protenus, Prinsius bisulcus, Sphenolithus radians, Transversopontis obliquipons, and T. pulcher.

\section{EOCENE THROUGH PALEOCENE ( $\cong 5,000$ FEET TO $\cong \mathbf{5 , 0 2 0}$ FEET)}

The interval bounded by the samples from $5,000-5,010$ feet and from 5,010-5,020 feet is composed of calcareous sediments of earliest Eocene to latest Paleocene age. On the basis of the following assemblage, these strata are placed in the Discoaster multiradiatus and Dis- coaster diastypus Zones of Bukry $(1973,1975)$ : Campylosphaera dela, Cepekiella lumina, Chiasmolithus solitus, Coccolithus jugatus of Proto Decima and others (1975), C. pelagicus, C. petrinus, Cyclococcolithina formosa, C. gammation, Discoaster barbadiensis, $D$. binodosus, $D$. distinctus, D. elegans, D.-lenticularis, D. multiradiatus, Discoasteroides kuepperi, Ellipsolithus distichus, Fasciculithus involutus, Helicosphaera lophota, H. seminulum, Markalius inversus, Neococcolithes dubius, Transversopontis fimbriatus, T. obliquipons, T. pulcher, and Zygrhablithus bijugatus.

The Eocene section in the COST No. B-2 well, is considered to be 1,000 feet or more thick. Future, more detailed investigations may reveal the existence of a fairly complete record of the Eocene in this well.

\section{CRETACEOUS \\ $($ FROM $\cong 5,110$ FEET)}

The Tertiary-Upper Cretaceous boundary is at approximately 5,110 feet in this well. In contrast to the carbonate rocks of the Paleogene sequence, the sample from 5,110 to 5,140 feet is composed of terrigenous clastic sediments containing rare but well-preserved calcareous nannofossils of Campanian Age. Other fossiliferous strata from the Cretaceous in this well are appreciably more calcareous. In general, however, these older rocks have a terrigenous aspect, and much of the section is of nonmarine origin.

The interval from 5,390 feet to 6,010 feet (samples from 5,390-5,400 feet, 5,510-5,520 feet, 5,800-5,810 feet, and 6,000-6,010 feet) contains the following assemblage, considered to represent the Campanian (Broinsonia parca, a Campanian and early Maestrichtian marker, was observed in samples from 5,800 to 5,810 feet and 6,000 to 6,010 feet.): Ahmuellerella octoradiata, Arkhangelskiella cymbiformis, Biscutum blackii, Braarudosphaera bigelowii, Broinsonia parca, Chiastozygus amphipons, $C$. plicatus, Corollithion achylosum, C. signum, Cretarhabdus conicus, C. crenulatus, Cribrosphaerella ehrenbergii, Eiffellithus eximius, $E$. turriseiffeli, Gartnerago costatum, Kamptnerius magnificus, $K$. percivalii, $K$. punctatus, Lucianorhabdus cayeuxii, Manivitella pemmatoidea, Microrhabdulus decoratus, Micula staurophora, Parhabdolithus embergeri, Percivalia porosa, Podorhabdus orbiculofenestrus, Predis- 
cosphaera cretacea, $P$. spinosa, Tetralithus obscurus, Vagalapilla elliptica, $V$. imbricata, $V$. matalosa, Watznaueria barnesae, Zygodiscus acanthus, $Z$. compactus, and $Z$. diplogrammus.

The beds from 6,010 feet to 7,300 feet were examined at 300-foot intervals and were found to be barren of calcareous nannofossils.

Strata thought to be of Turonian Age are present in the interval between 7,300 feet and 7,610 feet (samples from 7,300-7,310 feet and 7,600-7,610 feet). Kamptnerius magnificus, Lucianorhabdus cayeuxi, and Microrhabdulus decoratus are not recorded from below 6,010 feet. Eiffellithus eximius, Gartnerago costatum, and Micula staurophora are not formed below the sample from 7,300 to 7,310 feet, and Ahmuellerella octoradiata and Gartnerago segmentatum are not found below the sample from 7,600 to 7,610 feet. The following assemblage was identified in this interval: Ahmuellerella octoradiata, Arkhangelskiella cymbiformis, Bráarudosphaera bigelowii, Chiastozygus amphipons, C. plicatus, Corollithion signum, Cretarhabdus conicus, C. crenulatus, Cribrosphaerella ehrenbergii, Eiffellithus eximus, E. turriseiffeli, Gartnerago costatum, G. segmentatum, Lithastrinus floralis, Manivitella pemmatoidea, Micula staurophora, Prediscosphaera cretacea, Tetralithus obscurus, Vagalapilla elliptica, Watznaueria barnesae, Zygodiscus acanthus, $Z$. compactus, $Z$. diplogrammus.

Sediments from the interval bounded by samples from 7,900 to 7,910 feet and 8,200 to 8,210 feet contain a calcareous nannofossil assemblage characterized by long-ranging species.
Many species that evolved during the Turonian and were recorded in higher samples from the COST No. B-2 well are absent. The presence of Prediscosphaera cretacea indicates that these sediments are no older than Albian, and they are tentatively assigned an age of Cenomanian and Albian: Biscutum blackii, Chiastozygus amphipons, C. plicatus, Corollithion achylosum, C. signum, Cretarhabdus conicus, C. crenulatus, Eiffellithus turriseiffeli, Lithastrinus floralis, Manivitella pemmatoidea, Parhabdolithus angustus, $P$. asper, $P$. embergeri, Podorhabdus orbiculofenestrus, Prediscosphaera cretacea, Watznaueria barnesae, Zygodiscus acanthus, $Z$. compactus, and $Z$. diplogrammus.

Samples from 8,500 to 8,510 feet and 8,800 to 8,810 feet also contain many long-ranging species. Prediscosphaera cretacea is present, a species restricted to Albian and younger strata, and the occurrence in these two samples of Rucinolithus irregularis, a species recorded only from the Albian and Aptian, points to an Albian Age for the sediments of this interval: Chiastozygus plicatus, Corollithion achylosum, C. signum, Cretarhabdus conicus, Eiffellithus turriseiffeli, Lithastrinus floralis, Manivitella pemmatoidea, Markalius circumradiatus, Parhabdolithus embergeri, Prediscosphaera cretacea, Rucinolithus irregularis, Vagalapilla matalosa, Watznaueria barnesae, and Zygodiscus diplogrammus.

The strata from depths below 8,810 feet, examined at 300-foot intervals, were found to be barren of calcareous nannofossils. 


\title{
Palynomorph Biostratigraphy
}

\author{
By R. A. Scott and E. I. Robbins
}

Brenner (1963), Wolfe and Pakiser (1971), Sirkin (1974), Robbins and others (1975), Wolfe (1976), and Doyle and Robbins (in press) have reviewed the development of a palynological zonation for the sequence of both exposed and subsurface Cretaceous beds along the Atlantic Coastal Plain from South Carolina to Rhode Island. These informal zonations have been established primarily for the Barremian and younger strata of the emerged Coastal Plain. The striking record of the entry and evolution of the angiospermous pollen in Cretaceous strata forms the basis for clarifying many stratigraphic relationships among beds that have been difficult to separate on lithologic grounds.

Some evidence about the composition of earlier Cretaceous (Neocomian) floras of the region is furnished by spore assemblages from lower depths, for example, below 5,401 feet in the E. G. Taylor well (Accomack County, Va.) and below 5,612 feet in the J. D. Bethards well (Worcester County, Md.) (see Doyle and Robbins, in press), as well as both spore and dinoflagellate assemblages of Hauterivian to Berriasian Age in DSDP hole 105 (Habib, 1976, and in press). Palynological evaluations at the Cretaceous-Jurassic boundary have been made elsewhere in North America (Pocock, 1962; Williams, 1974; Norris and others, 1975) and in Europe (Norris, 1970).

The purposes of this preliminary report are threefold: (1) to discuss the palynomorph biostratigraphy of sediments present in the COST No. B-2 well; (2) to determine whether the hole penetrated beds older than Cretaceous; and (3) to present a broad-based paleoecological framework. Fifty-four samples were selected at intervals of approximately 300 feet. At least a few palynomorphs were present in almost every sample, although the number of forms and their preservational quality varied greatly among the samples. Although the cuttings were washed carefully, there is evidence of at least slight contamination by rare dicotyledonous pollen grains in deep levels of the well.

\section{RESULTS}

Pollen from the interval from 5,200 to 5,230 feet is regarded as Eocene in age (Norman Fredericksen, oral commun., 1976). Furthermore, F. E. May (written commun., 1976) identified the following Tertiary dinoflagellates: Deflandrea phosphoritica, Hystrichokolpoma rigaudae, Thalassiphora delicata, T. pelagica, Wetzeliella clathrata, and W. symmetrica. The age of the sample would appear to be Eocene on the basis of the presence of the two species of Wetzeliella. However, the interval could range as low as early Maestrichtian on the basis of the presence of the triaperturate angiospermous pollen C3B-3 (Wolfe, 1976, pl. 3) and MPD-1 (Wolfe, 1976, pl. 4).

The interval from 5,410 to 5,830 feet contains pollen indicative of a Maestrichtian to Santonian Age, as shown by the following Normapolles genera: Plicapollis sp., Praebasopollis sp., and Pseudoplicapollis sp. On the basis of the presence of the dinoflagellate cysts Paleohystrichophora infusorioides and Phoberocysta ceratioides, a Campanian or Santonian Age is confirmed (F. E. May, written commun., 1976). F. E. May located the Tertiary-Cretaceous boundary, on the basis of dinoflagellates, at from 5,230 to 5,410 feet.

From 6,120 to 7,330 feet, Zone V (Santonian to Turonian?) pollen is recognized on the basis of the association of Group 13, Krutzsch (1957), Pseudoplicapollis sp. and Triatriopollenites sp.

Zone IV pollen, which is present from 7,620 to 7,630 feet (lower Turonian? to middle 
Cenomanian), is recognized on the basis of the occurrence of Complexiopollis, Tricolpites vulgaris, and many unidentified tricolporates.

Zone III is identified in the interval from 7,920 to 7,930 feet on the basis of the association of Straitopollis sp. B of Doyle and Robbins (in press), Tricolporoidites bohemicus, and "Tricolporopollenites" distinctus. This zone has been dated as early Cenomanian.

From 8,220 to 8,840 feet, the association is suggestive of Subzone II C (upper Albian), as indicated by the association of Rugubivesiculites rugosus, Granulatisporites dailyi(?), Lycopodiumsporites triangularus, and "Tricolporopollenites"distinctus. The sample is too contaminated by Late Cretaceous and Miocene pollen to yield a confident correlation.

In the interval from 8,520 to 8,530 feet, the association of Rugubivesiculites reductus, $R$. rugosus, Cicatricosisporites subrotundus, and Taurocusporites spackmani with the angiosperm species Clavatipollenites tenellis, "Peromonolites" peroreticulatus, Tricolporoidites subtilis, and "Tricolporopollenites" triangulus suggests that the sample is late Albian in age (Subzone II $\mathrm{C}$ ). This assemblage also includes dinoflagellates of this age.

The sample from 8,820 to 8,830 feet contains the following Subzone II B (upper to middle Albian) species of angiosperms: Clavatipollenites tenellis, aff. "Foveotricolpites" concinnus, cf. Liliacidites sp. D of Doyle and Robbins (in press), two unidentified species of Liliacidites, "Retitricolpites" prosimilis, "R." vermimurus, and Tricolpites georgensis.

Varying quantities of pollen and spores in the interval from 9,120 to 11,890 feet can be correlated with Zone I (lower Albian to Barremian). Important species include: Cicatricosisporites aralica, C. dorogensis, Concavissimisporites variverrucatus, Gleicheniidites apilobatus, Klukisporites pseudoreticulatus, Parvisaccites amplus, as well as the angiosperms Clavatipollenites hugesii, aff. C. tenellis, and Retimoncolpites dividuus.

Dinoflagellates occur intermittently in the interval from 9,120 to 11,890 feet; for example, at 11,560 to 11,590 feet, 11,260 to 11,290 feet, 10,020 to 10,030 feet, and 9,720 to 9,730 feet. Study of the dinoflagellate assemblages will undoubtedly provide a record of fluctuating marine incursions. F. E. May (written commun., 1976) believes that the dinoflagellates in the interval 11,260 to 11,290 feet are of Barremian Age.

The intervals between 12,160 to 16,030 feet contain a typical pre-Zone I assemblage (preBarremian). Some species identified from the interval include: Parvisaccites sp., Podocarpidites potomacensis, Vitreisporites pallidus, Appendicisporites sp., Deltoidospora sp., Leptolepidites sp., Lycopodiacidites sp., abundant Pilosisporites trichopapillosus, Taurocusporites sp., Todisporites sp., and Trilobosporites sp.

In the deepest sample, from 16,020 to 16,030 feet, the following taxa were recognized: Alisporites sp., Podocarpidites sp., Classopollis sp., Ephedripites multicostatus, Eucommiidites troedssonii, Cicatricosisporites sp., and Concavissimisporites $\mathrm{sp}$.

Although the presence of Appendicisporites sp. suggests an Early Cretaceous age for these basal samples, the occurrence of Ephedripites multicostatus in the basal sample allows a correlation with the Ephedripites multicostatus Zone (Hauterivian to Berriasian) of Habib (1976, and in press) from DSDP hole 105.

The presence of megaspores in several samples, including the lowest one $(16,020$ 16,030 feet), reinforces an Early Cretaceous age for the base. The megaspores have been examined by R. H. Tschudy (oral commun., 1976), who found no taxa that have been recognized in North America below the upper Lower Cretaceous; little information is available from lower Lower Cretaceous beds. None of the megaspores described from the Upper Jurassic of Greenland (Harris, 1935) or of England (Murray, 1939) was present among forms found in this well.

Thus, there appears to be only a slight possibility, implicit in the incompleteness of the dating of assemblages from elsewhere in North America and northern Europe, that Jurassic beds are present in the COST No. B-2 well.

\section{PALEOECOLOGY}

Study of the palynomorphs, as well as plant fragments, algae and fungi, the type of sapropel, and the presence of pyrite crystals in samples prepared for sapropel studies (see section "Color Alteration of Visible Organic Matter") has also yielded paleoenvironmental information, indicating the following environmental conditions: 610 to 3,790 feet, alternating nearshore marine, brackish, and nonmarine; 3,790 to 4,880 feet, open-marine; 
4,880 to 6,430 feet, nearshore; 6,430 to 8,530 feet, alternating nonmarine and marine. In the interval from 8,530 to 11,290 feet, the organic matter is largely nonmarine and primarily oxidized or degraded by bacteria. From 13,330 feet to the bottom of the well, the organic matter is largely terrestrially derived.

\section{CONCLUSIONS}

In summary, palynomorphs were obtained from most of the cuttings studied between 1,030 and 16,030 feet from the COST No. B-2 well. The Tertiary-Cretaceous boundary, determined on the basis of dinoflagellates, is found between 5,230 and 5,410 feet. Late Cretaceous dicotyledonous pollen, equivalent to
Zones V, IV, and III in the Atlantic Coastal Plain informal pollen zonation, is present between 5,410 and 7,930 feet in the COST No. B2 well. An Early Cretaceous spore assemblage equivalent to Subzones II C, II B, Zone I, as well as the Ephedripites multicostatus Zone of Habib (1976, and in press) extends to the lowest level sampled, 16,020 to 16,030 feet. Early Cretaceous megaspores are present in the lowest samples, including the lowest one examined. Evidence at hand indicates that the COST No. B-2 well bottoms in Lower Cretaceous beds and thus penetrates at least 9,000 feet of Cretaceous sediments. However, the possibility that some Upper Jurassic is present in the basal samples cannot be excluded. 


\title{
Geothermal Gradients
}

\author{
By E. I. Robbins
}

Present-day subsurface temperatures can be used to give an approximate idea of the depth range of maximum hydrocarbon generation (liquid petroleum window) in a basin. This can be particularly useful when other studies are performed to determine whether the modern temperatures are the highest to which the section has been subjected.

For the COST No. B-2 well, 29 geothermal values have been plotted (fig. 9) using approximate equilibrium temperatures calculated from the five available temperature logs. A linear regression was computed using these points; it shows a systematic increase in temperature with depth (correlation coefficient $=0.98$ ). The geothermal gradient is calculated to be $1.3^{\circ} \mathrm{F} /$ $100 \mathrm{ft}$ with a surface intercept of $75.7^{\circ} \mathrm{F}$. A geothermal gradient of $1.3^{\circ} \mathrm{F} / 100 \mathrm{ft}$ is rather typical for basins around the North Atlantic Ocean (table 9). An alternative method of calculating geothermal gradients, by using the present-day mean annual surface temperature $\left(52^{\circ} \mathrm{F}\right)$ and the bottom-hole temperature, yields a thermal gradient of $1.5^{\circ} \mathrm{F} / 100 \mathrm{ft}$ (Smith and others, 1976).

The liquid petroleum window is based largely on empirical observation and generally is con- sidered to have a lower limit of about $150^{\circ} \mathrm{F}$ and an upper limit of $270^{\circ}$ to $300^{\circ} \mathrm{F}$ (Pusey, 1973; Harrison, 1976). The upper temperature limit may be significantly higher if heating times are short. Using the present geothermal gradient, the liquid petroleum window (fig. 9) would be expected to occur between 5,700 and 17,000 feet, provided these temperatures are maintained over a significant period of time. Work on vitrinite reflectance, visual analysis of color alteration of organic matter, and organic geochemistry all suggest that similar or slightly lower geothermal gradients may have prevailed in the past. However, most reconstructions of the geologic history of the area (Bott, 1971; Sleep, 1971, Falvey, 1974) would predict considerably higher geothermal gradients in the past, particularly during Triassic and Jurassic rifting events. Thus, some conflict remains between the direct thermal analyses of the COST No. B-2 well sediments and both present and inferred past geothermal history. Certainly, the thick sedimentary section that underlies the rocks penetrated by the COST No. B-2 well may have been influenced by higher geothermal gradients.

TABLE 9.-Circum-Atlantic off shore geothermal gradients

\begin{tabular}{|c|c|c|}
\hline Basin & $\underset{\left({ }^{\circ} \mathrm{F} / 100 \mathrm{ft}\right)}{\text { Gradient }}$ & Reference \\
\hline $\begin{array}{l}\text { Scotian Shelf basin } \\
\text { Southern North Sea } \\
\text { Baltimore Canyon basin } \\
\text { Niger Delta shelf } \\
\text { South Pass, La. } \\
\text { Offshore Louisiana }\end{array}$ & $\begin{array}{l}1.2 \\
1.7 \\
1.3 \\
1.4 \\
1.2 \\
1.3\end{array}$ & $\begin{array}{l}\text { Robbins and Rhodehamel, } 1976 . \\
\text { Harper, } 1971 . \\
\text { This paper. } \\
\text { Nwachukwu, } 1976 . \\
\text { Pusey, } 1973 \text {. } \\
\text { Jam and others, } 1969 .\end{array}$ \\
\hline
\end{tabular}




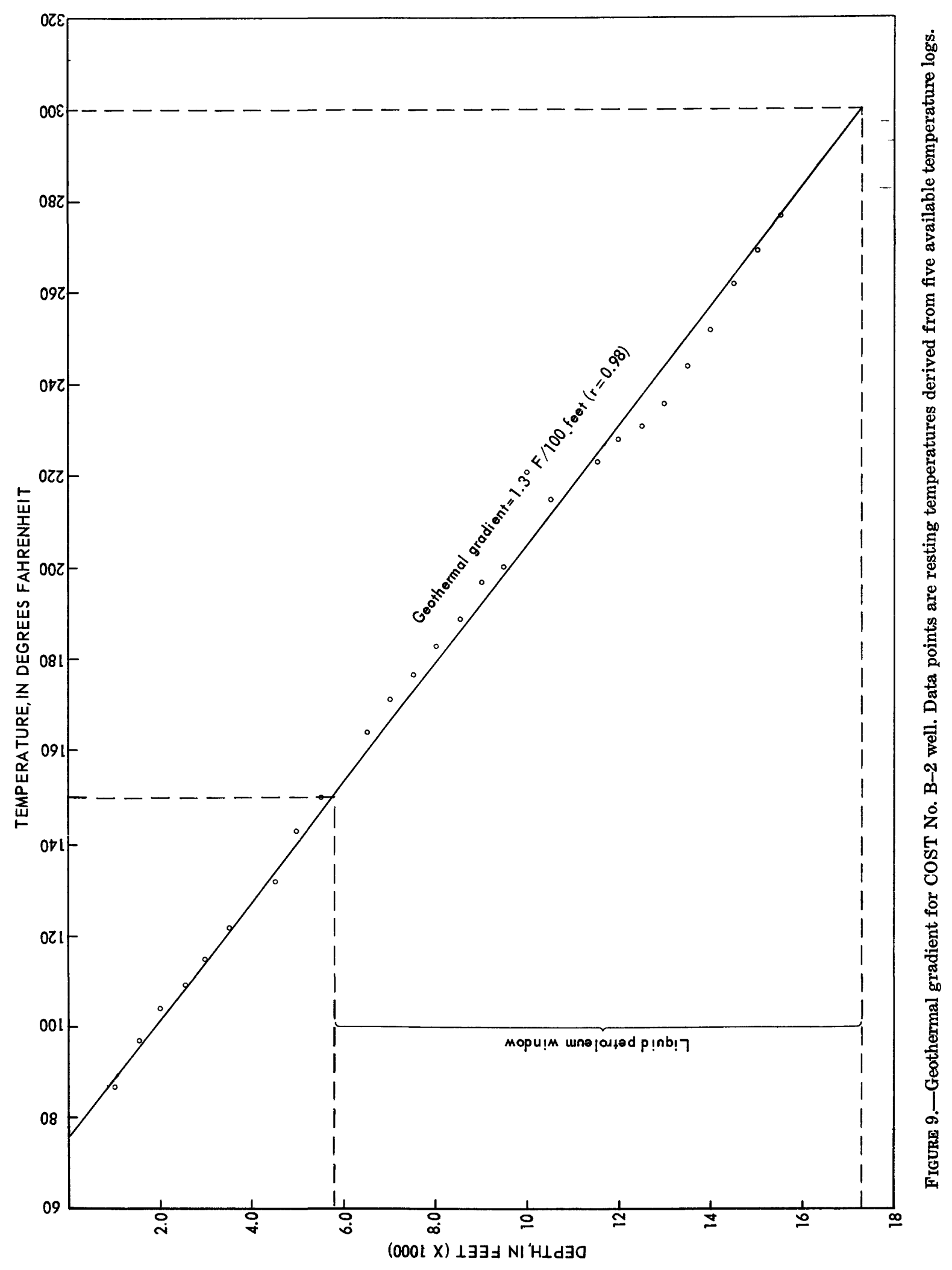




\title{
Organic Geochemistry
}

\author{
By G. E. Claypool, C. M. Lubeck, J. P. Baysinger, and T. G. Ging
}

Thirty-four samples of unwashed cuttings have been analyzed by combustion and thermal analysis/pyrolysis-FID techniques to evaluate petroleum source-rock potential. In addition, six of the samples were analyzed for light hydrocarbon $\left(\mathrm{C}_{1}-\mathrm{C}_{7}\right)$ content, and five samples of washed, handpicked cuttings were analyzed for extractable hydrocarbons by solvent extraction, column chromatography, and gas chromatography. The thermal analysis technique was the same as that described by Claypool and Reed (1976), except that the rate of heating was $104^{\circ} \mathrm{F} / \mathrm{min} \quad\left(40^{\circ} \mathrm{C} / \mathrm{min}\right)$ instead of $82^{\circ} \mathrm{F} / \mathrm{min}\left(28^{\circ} \mathrm{C} / \mathrm{min}\right)$. The flame-ionization response was converted to an equivalent weight of hydrocarbons by using an empirical calibration based on secondary standards analyzed by Fisher assay. The organic carbon and solventextraction techniques were adopted from those described by Baker and Claypool (1970).

The following criteria are used in this section to evaluate petroleum source-rock potential :

1. Organic richness-Sedimentary rocks must contain a sufficient quantity of organic matter that can be or that has been converted to petroleum hydrocarbons. Measurements used to indicate sufficient organic richness for petroleum sourcerock potential are either (a) pyrolytic oil yield in excess of about 0.2 to 0.3 percent; or (b) extractable hydrocarbon concentrations in excess of about 100 to 500 ppm.

2. Maturity-The conversion of organic matter to petroleum hydrocarbons takes place by temperature-dependent chemical reactions. Sedimentary rocks that are rich in organic matter and in which the petroleum-generating reactions have not ad- vanced to a degree sufficient to expect expulsion and accumulation of petroleum are called immature. The principal criteria used to determine the extent of petroleum-generating reactions are the molecular composition and the relative concentration of indigenous extractable hydrocarbons. When the extractable hydrocarbons are chemically indistinguishable from petroleum and are present at levels in excess of about 1 to 2 percent of the total organic carbon, the rock is mature. When a rock is known to be capable of generating petroleum hydrocarbons (for example, by pyrolysis) but contains a relatively low concentration of largely biochemically derived hydrocarbons, then the hydrocarbon-generating reactions are not sufficiently advanced, and the rock is immature.

By using these criteria of maturity and richness in organic matter, we can distinguish the following categories of petroleum source rocks : Potential source rock-A sedimentary rock that is rich in organic matter and that is immature. This is a potential source rock in the sense that hydrocarbon generation may have taken place in laterally equivalent strata, if higher temperatures prevailed (for example, deeper burial) ; however, it is not practical to wait for the sedimentary section in question to realize its hydrocarbon-generating potential.

Possible source rock-A sedimentary rock that is rich in organic matter and that is mature. This rock has realized its potential for generating hydrocarbons (that is, it contains petroleumlike hydrocarbons).

Many other chemical and physical measurements relate to the interpretation of richness in 
organic matter and, especially, maturity. However, these properties or observations are indirectly related to petroleum occurrence or generation. For purposes of petroleum sourcerock evaluation, the direct measurement of the approximate degree of completion of hydrocarbon-generating reactions (where possible) is preferable to an inference based on indirectly related properties.

\section{RESULTS AND CONCLUSIONS}

Although potential source rocks are present in the lower part of the COST No. B-2 well, the presence of fully mature oil source rocks was not confirmed. The organic matter in all samples analyzed appears to be immature in greater or lesser degree with respect to the degree of liquid-petroleum-hydrocarbon generation required for expulsion and economic occurrence of petroleum. This conclusion is based primarily on the nonpetroleum characteristics of the saturated-hydrocarbons, that is, the predominance of $n$-paraffins containing an odd number of carbon atoms $\left(\mathrm{nC}_{27}\right.$ to $\left.\mathrm{nC}_{31}\right)$ in the five samples analyzed. Additional support for this conclusion is provided by the relatively low temperatures of maximum pyrolysis yield, indicating coal rank in the subbituminous to high-volatile bituminous range. Although the deepest rocks that are rich in organic matter appear not to be fully mature, the hydrocarbon-generating reactions are definitely in progress. Moreover, the rocks below 14,000 feet in this well contain such small quantities of organic matter that geochemical methods for evaluation of maturity are of questionable applicability. If rocks of sufficient organic richness were present, they might well be fully mature at, or just below, the bottom of the well.

The results of the combustion and thermal analysis/pyrolysis FID measurements are given in table 10. The trend of increasing temperature of maximum pyrolysis yield as a func-

TABLE 10.-Organic content of sediments from the COST No. B-2 well, obtained by combustion and thermal analysis/pyrolysis

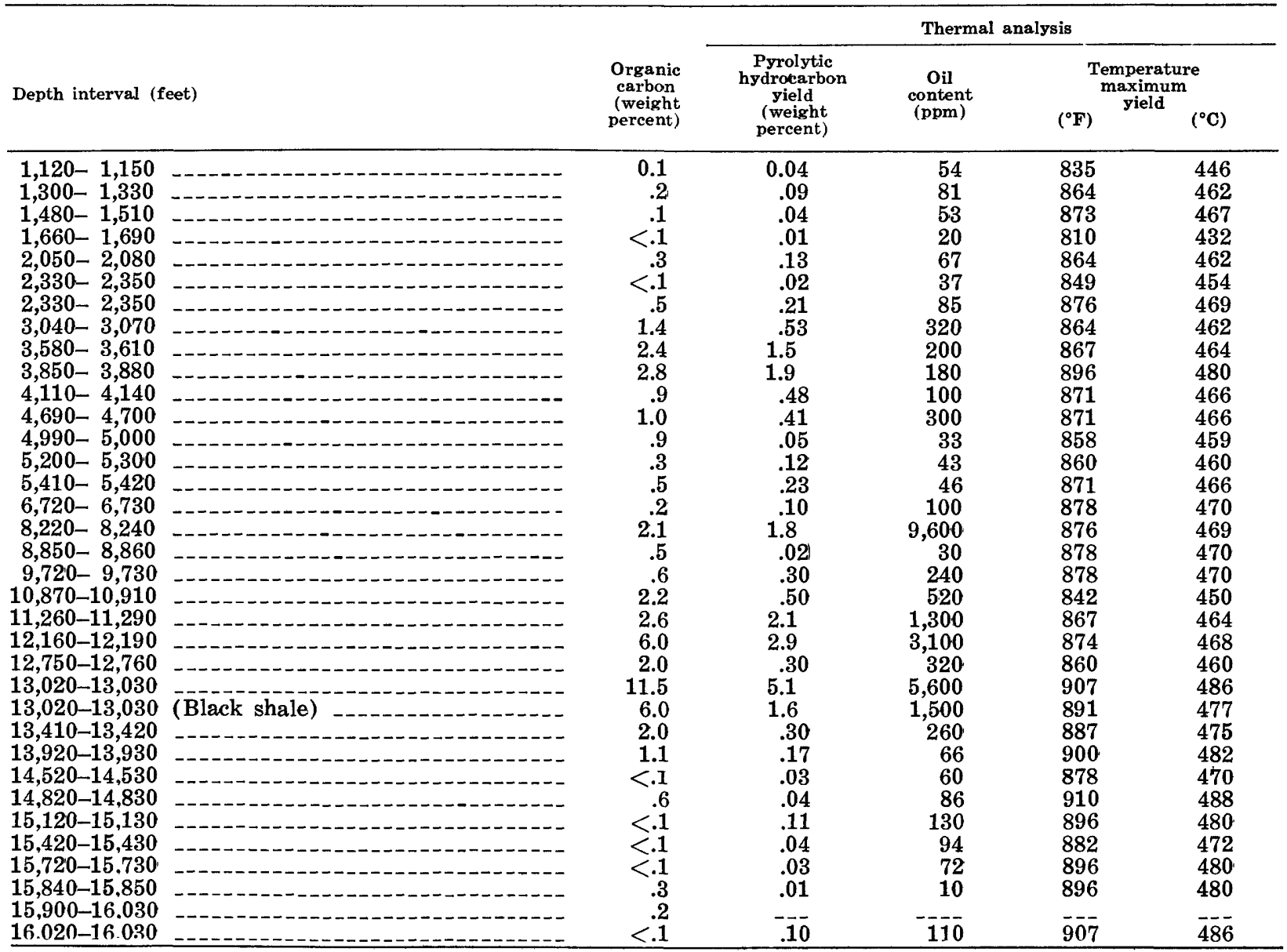




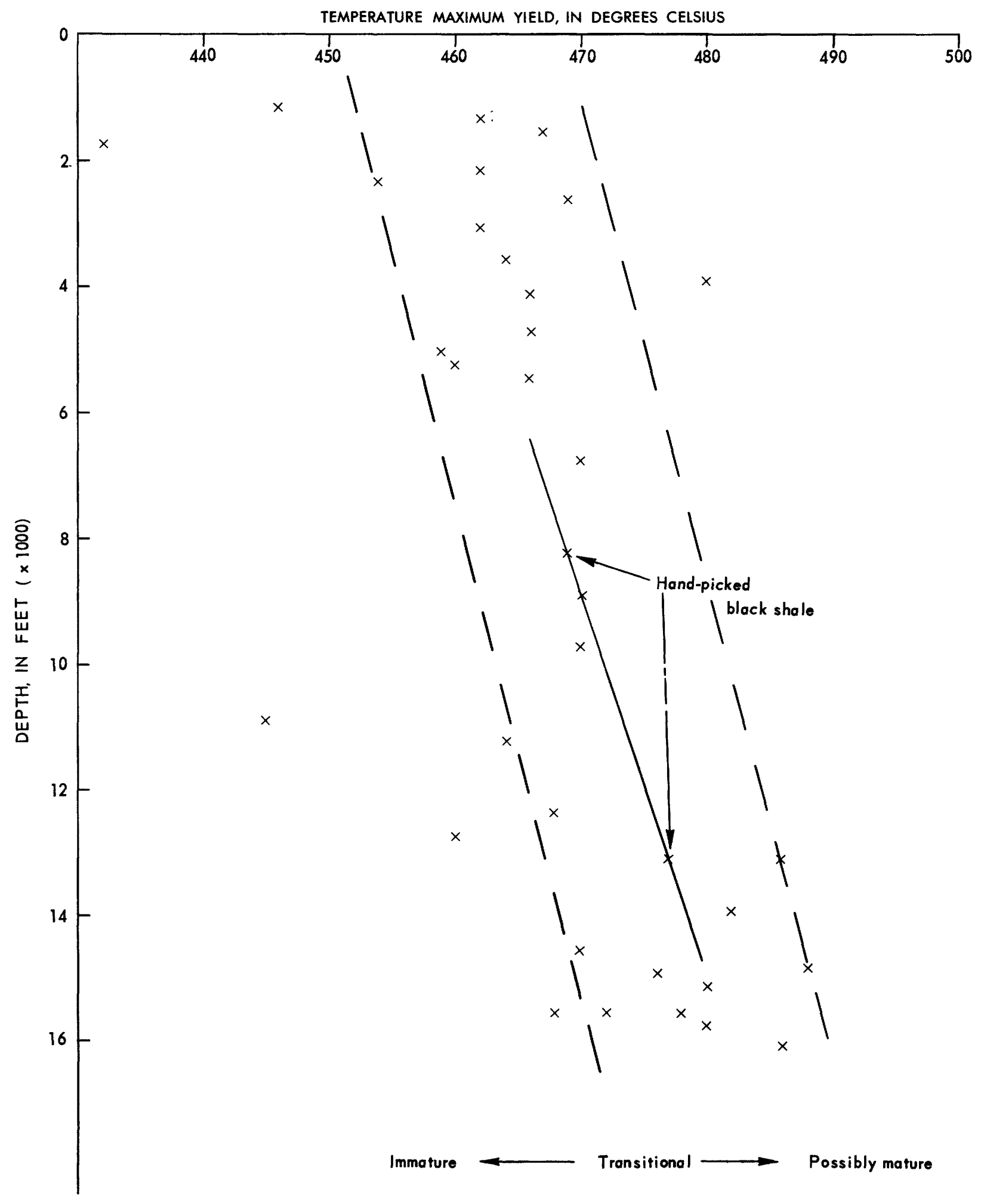

FIGURE 10.-Temperature of maximum pyrolysis yield as a function of depth. 
tion of depth is shown in figure 10 for the COST No. B-2 well; it is superimposed on the tentative calibration based on analysis of standard coals, shown in figure 11.

Samples from depth intervals of about 3,000 to 4,000 feet and about 8,000 to 14,000 feet are relatively rich in organic matter (greater than 2.0 percent organic carbon). Samples from the shallowest interval (3,040-3,070 feet and 3,580-3,610 feet) contain relatively low amounts of hydrocarbons (80 to $78 \mathrm{ppm}$, respectively) and have a marked odd carbonnumber predominance in the normal paraffins. These samples also show a relatively high conversion of organic matter to hydrocarbons upon pyrolysis ( 0.5 and 1.5 percent, where 0.3 percent is about the minimum value for rocks considered to be potential source rocks).

The samples at 8,220 to 8,240 feet and those in the range of 10,000 to 14,000 feet contain large amounts of volatile or thermally extractable organic matter, in addition to high contents of total organic carbon. In the sample from 8,220 to 8,240 feet, the material appears to be nonindigenous (oil staining or possible contamination) because the quantity of volatile organic matter is out of proportion to the total organic carbon content of the sample. However, the samples analyzed from 10,000 to 14,000 feet, especially the sample from 12,160 to 12,190 feet, contain high concentrations of apparently indigenous, solvent-extractable organic matter. The high concentrations of hydrocarbons are probably related to abundant coaly material in this part of the section, and the richness-in-organic-matter criteria for petroleum source-rock evaluation of shales are not strictly applicable.

More detailed analyses were performed to determine whether the section rich in organic matter between approximately 10,800 and 14,000 feet contains an assemblage of indigenous, petroleumlike hydrocarbons generated from the solid organic matter (that is, to determine whether the section is mature with respect to liquid-petroleum hydrocarbon generation). The results of the solvent-extraction analyses are summarized in table 11 . The sample from 12,160 to 12,190 feet has 2,680 ppm hydrocarbons and 6.0 percent organic carbon for a hydrocarbon-to-organic-carbon ratio of 4.5 percent. The other two samples from the deeper part of the section have hydrocarbon-to-organic-carbon ratios of 1.7 percent $(11,260-11,290$ feet) and 1.3 percent (15,90016,030 feet). These ratios are in contrast to values of 0.6 and 0.3 percent for the shallower samples (3,040-3,070 feet and 3,580-3,510 feet, respectively). Ratios in excess of 1 percent usually suggest that hydrocarbon generation has taken place. However, the more important question is whether or not this process is sufficiently advanced in the sections of this well that are rich in organic matter for expulsion and accumulation of liquid petroleum to have taken place.

The results of detailed analyses of the saturated hydrocarbons by gas chromatography are summarized in figures 12-16. The tendency for the odd-numbered n-paraffins to predominate over the neighboring evennumbered n-paraffins is summarized by the carbon preference index (CPI). A definite trend of CPI values approaches 1 as depth in the hole increases. This trend also indicates that some degree of hydrocarbon generation has taken place. However, the deepest samples analyzed that contain sufficient organic matter to be considered a potential petroleum source rock (12,160-12,190 feet, fig. 15) have a CPI

TABLE 11.-Summary of chloroform extraction-yields, column chromatographic separation of $C_{15+}$ hydrocarbon fractions, and estimate of carbon preference index (CPI) by gas chromatography from COST No. B-2 well samples

\begin{tabular}{|c|c|c|c|c|c|c|c|}
\hline \multirow[b]{2}{*}{$\begin{array}{c}\text { Depth interval } \\
\text { (feet) }\end{array}$} & & \multirow[b]{2}{*}{ 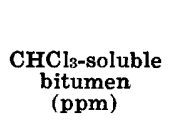 } & \multicolumn{5}{|c|}{ Extractable hydrocarbons } \\
\hline & & & $\begin{array}{c}\text { Saturated } \\
\text { (heptane eluate) } \\
\text { (ppm) }\end{array}$ & $\begin{array}{c}\text { Aromatic } \\
\text { (benzene eluate) } \\
(\mathrm{ppm})\end{array}$ & $\begin{array}{l}\text { Total } \\
\text { (sum) } \\
\text { (ppm) }\end{array}$ & CPI 1 & $\begin{array}{c}\text { Hydrocarbons } \\
\text { total organic } \\
\text { C }\end{array}$ \\
\hline $\begin{array}{r}3,040-3,070 \\
3,580-3,610 \\
11,260-11,290 \\
12,160-12,190 \\
15,900-16,030\end{array}$ & 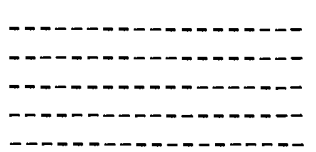 & $\begin{array}{r}311 \\
272 \\
893 \\
5,747 \\
77\end{array}$ & $\begin{array}{r}21 \\
30 \\
115 \\
710 \\
9\end{array}$ & $\begin{array}{r}60 \\
48 \\
315 \\
1,970 \\
16\end{array}$ & $\begin{array}{r}81 \\
78 \\
430 \\
2,680 \\
25\end{array}$ & $\begin{array}{r}3.4 \\
\sim 3.4 \\
1.5 \\
1.2 \\
1.2\end{array}$ & $\begin{array}{l}0.6 \\
0.3 \\
1.7 \\
4.5 \\
1.2\end{array}$ \\
\hline
\end{tabular}

${ }_{1} \mathrm{CPI}=\frac{\mathrm{nC}_{25}+\mathrm{nC}_{27}+\mathrm{nC}_{29}+\mathrm{nC}_{31}}{\mathrm{nC}_{28}+\mathrm{nC}_{28}+\mathrm{nC}_{30}+\mathrm{nC}_{32}}+\frac{\mathrm{nC}_{25}+\mathrm{nC}_{27}+\mathrm{nC}_{29}+\mathrm{nC}_{31}}{\mathrm{nC}_{24}+\mathrm{nC}_{26}+\mathrm{nC}_{28}+\mathrm{nC}_{30}}$ 


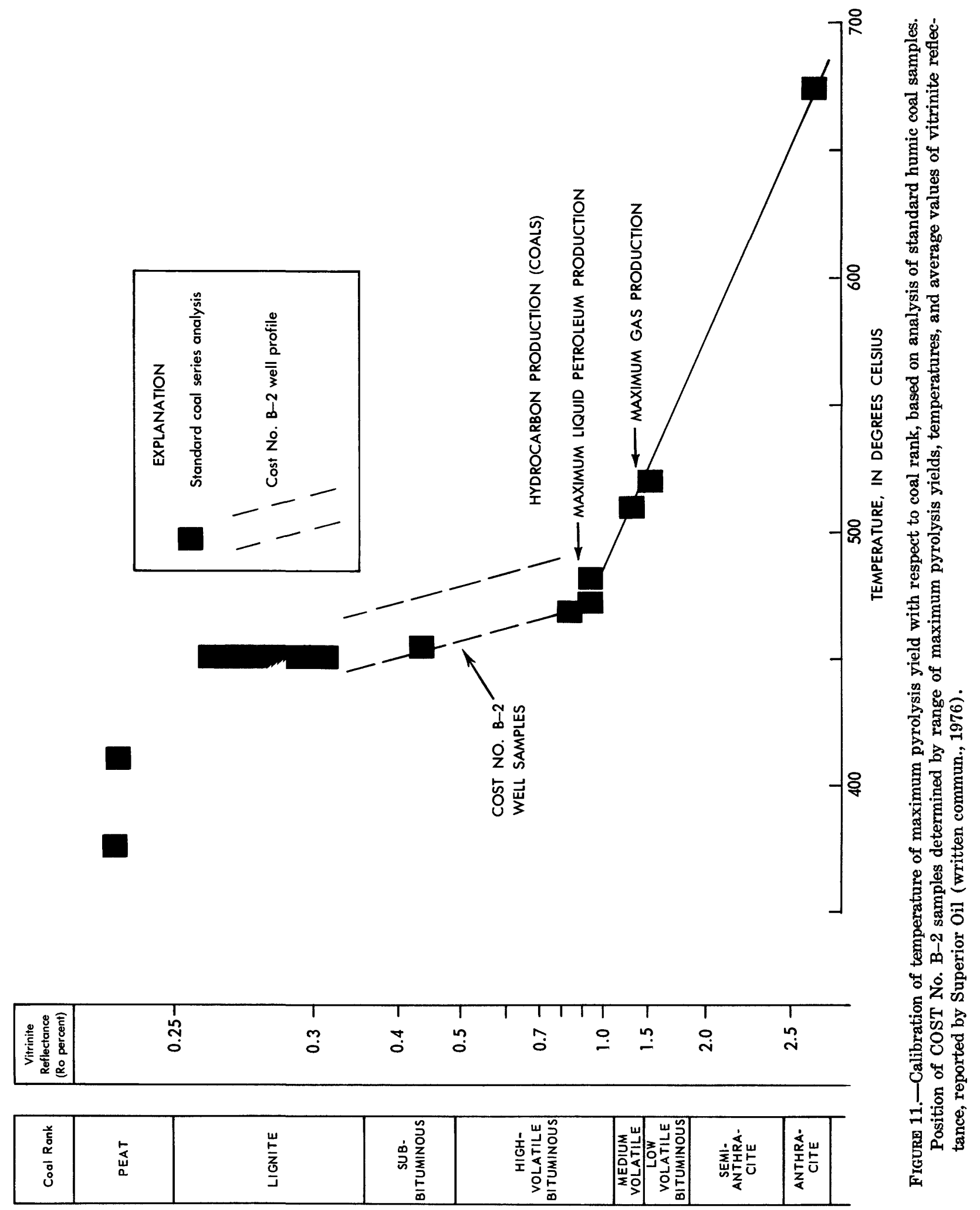




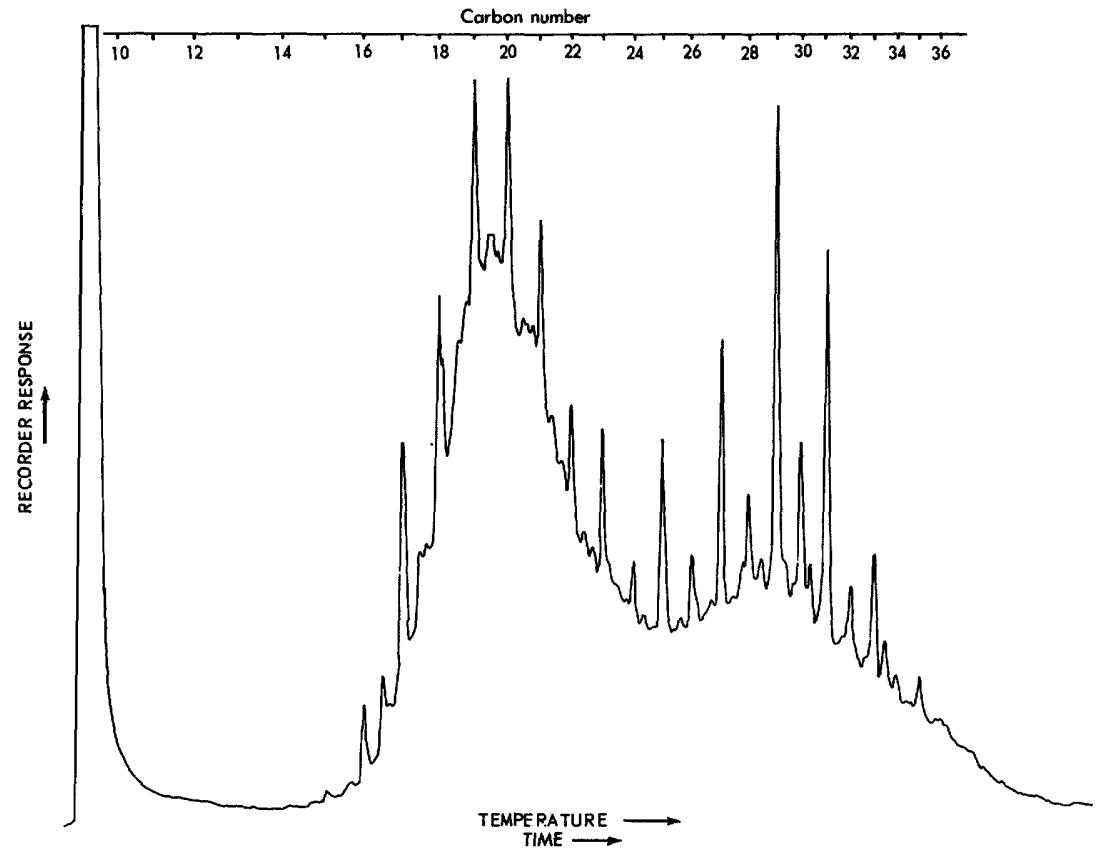

FIGURE 12.-Gas-chromatographic analysis of saturated hydrocarbons, COST

No. B-2 well, sample from 3,040 to 3,070 feet. Analysis on $20-\mathrm{mm} \times$ 1.8-m columns packed with 3.0-percent GCSE-30 on 100-120-mesh Gas Chrom Q; the flow was $40 \mathrm{~mL} / \mathrm{min}$. Column temperature was $80^{\circ} \mathrm{C}$ at injection and was programmed to rise $12^{\circ} \mathrm{C} / \mathrm{min}$ for $10 \mathrm{~min}$, then $10^{\circ} \mathrm{C} /$ $\min$ for $12 \mathrm{~min}$ to a final temperature of $320^{\circ} \mathrm{C}$.

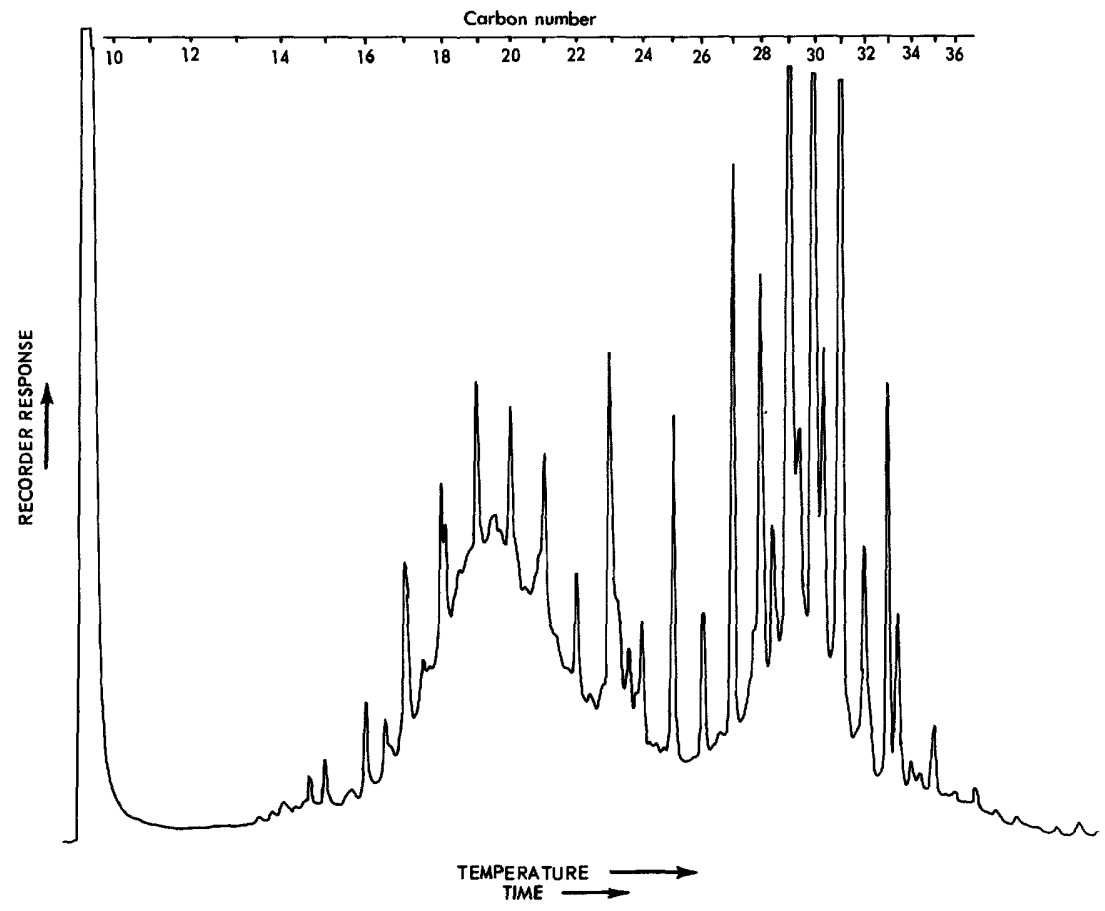

FIGURE 13.-Gas-chromatographic analysis of saturated hydrocarbons, COST No. B-2 well, sample from 3,580 to 3,610 feet. Conditions same as analysis shown in figure 12 . 


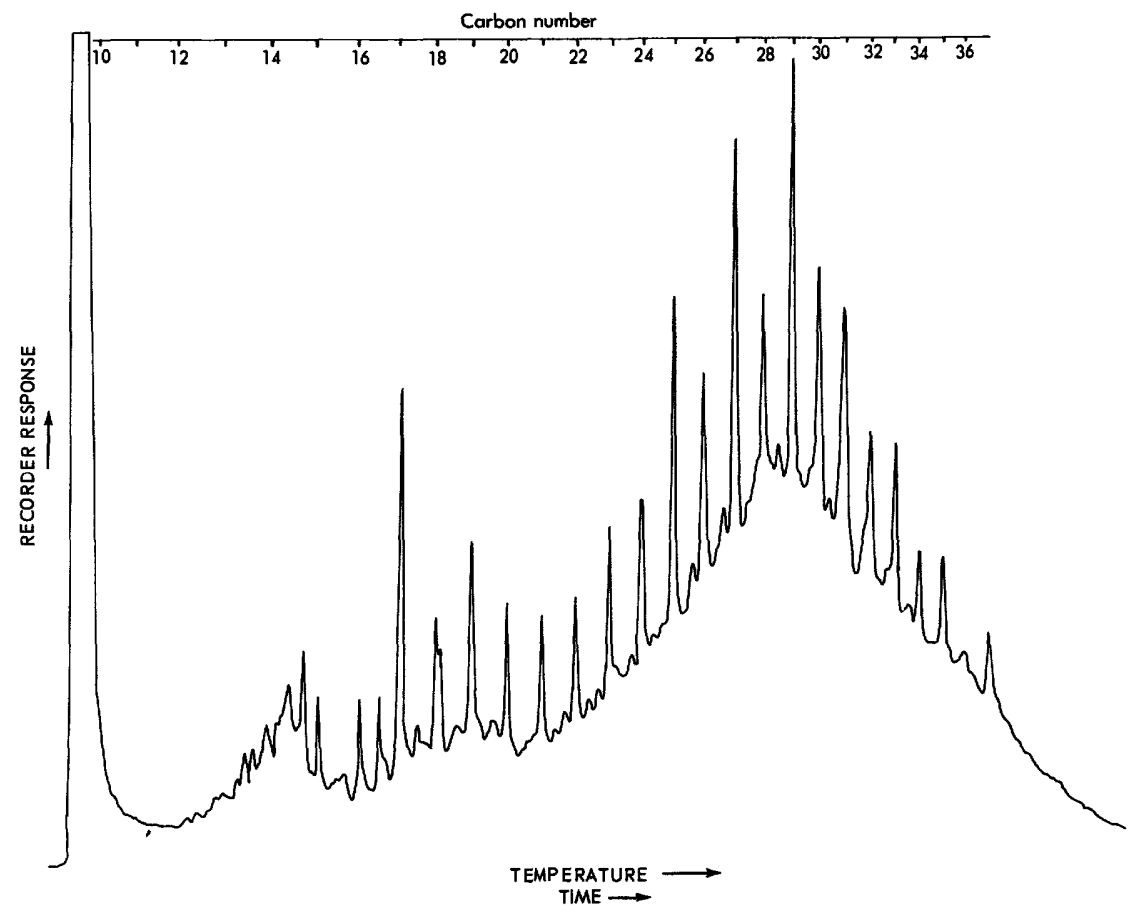

FIGURE 14.-Gas-chromatographic analysis of saturated hydrocarbons, COST No. B-2 well, sample from 11,260 to 11,290 feet. Conditions same as analysis shown in figure 12 .

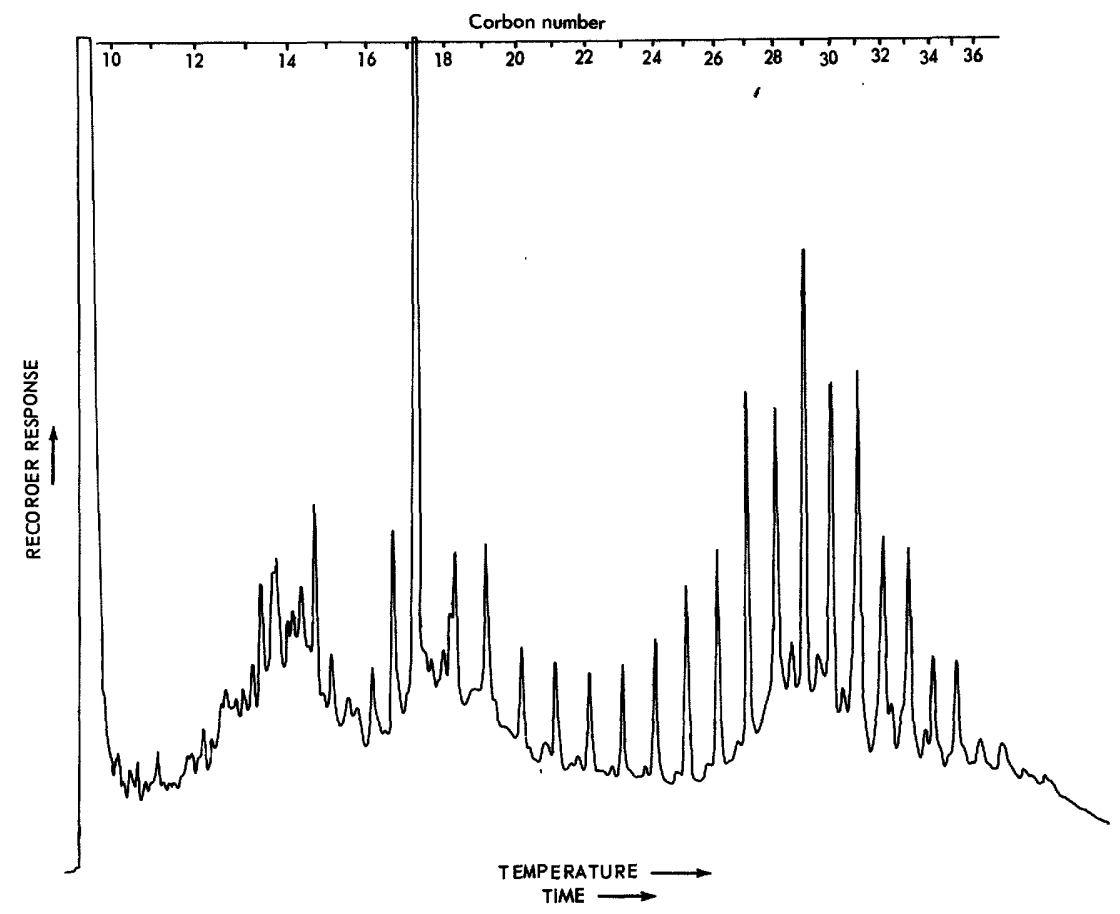

FIGURE 15.-Gas-chromatographic analysis of saturated hydrocarbons, COST No. B-2 well, sample from 12,160 to 12,190 feet. Conditions same as analysis shown in figure 12 . 


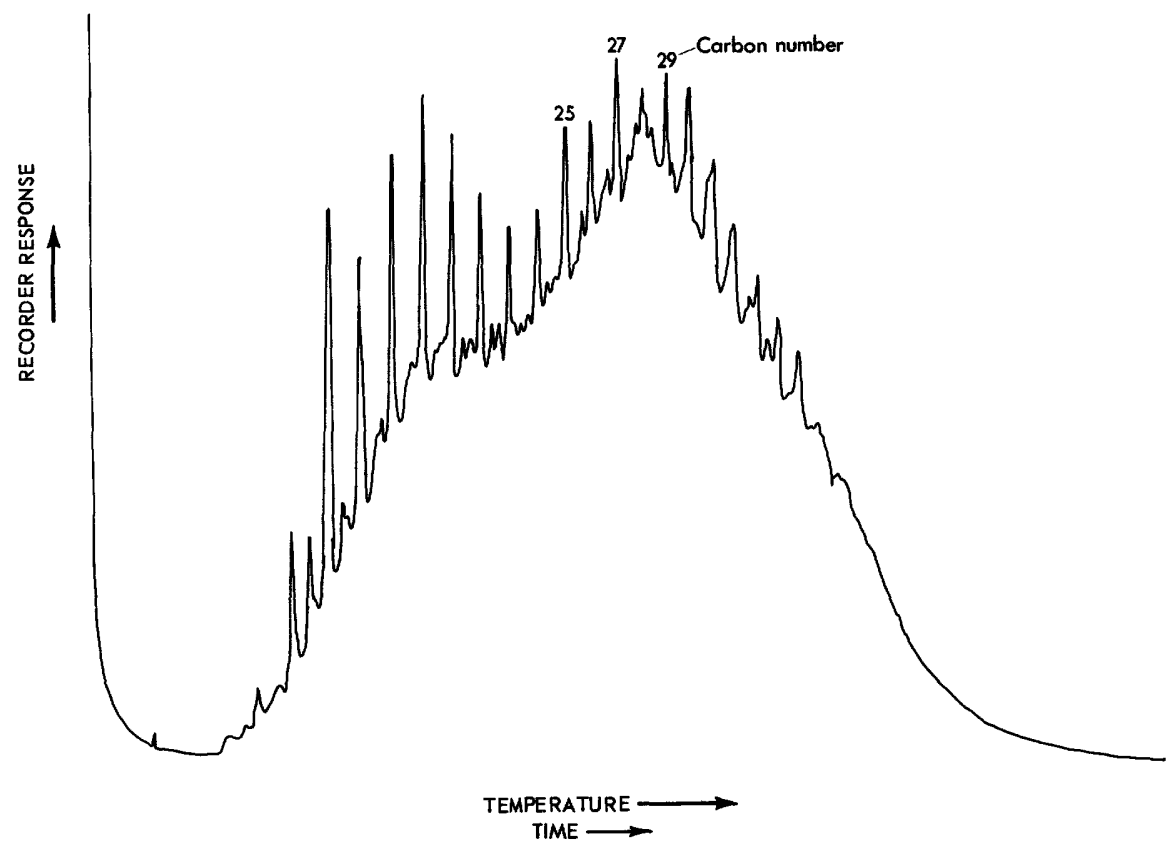

FIgURE 16.-Gas-chromatographic analysis of saturated hydrocarbons, COST No. B-2 well, sample from 15,900 to 16,030 feet. Conditions same as in the analysis shown in figure 12 .

value of 1.5 ; pristane is the most abundant single compound in the mixture. These are still the chemical characteristics of subbituminous coals (Brooks and Smith, 1967), whereas the principal phase of oil formation takes place at the high-volatile bituminous stage (Vassoyevich and others, 1970). At this latter stage, the mixture of saturated hydrocarbons resembles mature petroleum in having little or no oddcarbon-predominant n-paraffins and much smaller predominance of pristane in the total mixture.

Another analysis was performed on pieces of black shale handpicked from the interval 13,020 to 13,030 feet. The sample was heated in two stages-from room temperature to $680^{\circ} \mathrm{F}\left(360^{\circ} \mathrm{C}\right)$ and then from room temperature to $1,382^{\circ} \mathrm{F}\left(750^{\circ} \mathrm{C}\right)$-and the volatile and pyrolysis products produced during the two separate heating periods were analyzed by gas chromatography. Two different hydrocarbon mixtures are evident, indicating that the volatile organic matter was not produced by thermal alteration of the solid organic matter. In addition, the gas-chromatographic analysis of the pyrolysis products indicates liquid-hydrocarbon-generating potential (as opposed to gas only).

Six samples from the interval 8,850 to 15,850 feet were analyzed for light hydrocarbons in the headspace gas of a blender containing the cuttings and distilled water at $198^{\circ} \mathrm{F}\left(92^{\circ} \mathrm{C}\right)$. The results are shown in table 12 . The cyclic isomers in the $\mathrm{C}_{6}$ to $\mathrm{C}_{7}$ range are predominant, which is consistent with immaturity. The measured quantity of $\mathrm{C}_{1}$ to $\mathrm{C}_{7}$ hydrocarbons was in the range of $10^{-6}$ to $10^{-5}$ grams per gram of organic carbon. In mature petroleum-generating sediments, the corresponding range is $10^{-3}$ to $10^{-2}$. However, these samples were bagged cuttings that had been opened prior to analysis so that the quantities of gaseous and gasoline-range hydrocarbons measured are minimum values. Sample 13,410 to 13,420 feet had the highest content of $\mathrm{C}_{1}$ to $\mathrm{C}_{7}$ hydrocarbons and a significant proportion (51 volume percent) of permanent gases (methane, ethane, propane). As these samples were not collected and handled in a manner that would insure retention of dissolved or absorbed gases, this gas was probably released from the rock when the cuttings were disaggregated in the blender.

Although experimental evidence suggests that virtually the same temperatures are needed for gas- or liquid-hydrocarbon formation, an extensive body of empirical evidence shows that wet or dry gas is present and may form before crude oil, probably at temperatures starting 
TABLE 12.- $\mathrm{C}_{1}$ to $\mathrm{C}_{7}$ hydrocarbon analyses of selected samples from the COST No. B-2 well

[Values in volume percent of $\mathrm{C}_{1}$ to $\mathrm{C}_{7}$ hydrocarbons normalized to 100 percent]

\begin{tabular}{|c|c|c|c|c|c|c|}
\hline \multirow[b]{2}{*}{ Hydrocarbons } & \multicolumn{6}{|c|}{ Depth interval (in feet) } \\
\hline & $\begin{array}{l}8,850- \\
8,860\end{array}$ & $\begin{array}{l}10,870- \\
10,910\end{array}$ & $\begin{array}{l}12,750- \\
12,760\end{array}$ & $\begin{array}{l}13,410- \\
13,420\end{array}$ & $\begin{array}{l}14,820- \\
14,830\end{array}$ & $\begin{array}{l}15,840- \\
15,850\end{array}$ \\
\hline Methane+ethane -.-- & 0.0 & 2.6 & 2.8 & 25.8 & 7.1 & 37.5 \\
\hline Propane & .0 & 9.5 & 24.9 & 25.4 & 7.1 & 8.0 \\
\hline Isobutane & .0 & 5.2 & 9.1 & 4.7 & .0 & 4.0 \\
\hline n-Butane & .0 & 6.2 & 2.7 & 12.7 & 3.6 & 4.7 \\
\hline Isopentane & .0 & 8.5 & 12.9 & 4.8 & .9 & .0 \\
\hline n-Pentane & .0 & 4.8 & 10.7 & 3.8 & 1.8 & 2.2 \\
\hline 2,2-Dimethybutane & .0 & .0 & .0 & .0 & .0 & .0 \\
\hline Cyclopentane & .0 & 1.2 & 1.8 & .4 & .0 & .0 \\
\hline 2,3-Dimethylbutane & .0 & .6 & .4 & .1 & 5.3 & .0 \\
\hline 2-Methylpentane & .0 & 6.5 & 3.5 & 2.0 & .0 & 4.5 \\
\hline 3-Methylpentane & .0 & 2.6 & 2.3 & .8 & .0 & .0 \\
\hline $\mathrm{n}$-Hexane & .0 & 1.9 & 2.3 & .8 & .0 & .0 \\
\hline Methylcyclopentane & .0 & 9.3 & 6.8 & 1.8 & .0 & .0 \\
\hline 2,2-Dimethylpentane & .0 & .0 & .0 & .0 & .0 & .0 \\
\hline Benzene - & 55.0 & 6.6 & .9 & 4.8 & 21.1 & 12.5 \\
\hline 2,4-Dimethylpentane & .0 & .0 & .0 & .0 & .0 & .0 \\
\hline 2,2,3-Trimethylbutane & .0 & .0 & .0 & .0 & .0 & .0 \\
\hline Cyclohexane & 45.0 & 9.9 & 4.7 & 6.5 & 53.1 & 26.6 \\
\hline 3,3-Dimethylpentane & .0 & .0 & .0 & .0 & .0 & .0 \\
\hline 1,1-Dimethylcyclopentane -.-- & .0 & .0 & .1 & .0 & .0 & .0 \\
\hline 2-Methylhexane & .0 & .9 & .5 & .2 & .0 & .0 \\
\hline 2,3-Dimethylpentane & .0 & .7 & .2 & .0 & .0 & .0 \\
\hline 1,Cis-3-dimethylcyclopentane & .0 & 1.6 & .8 & .3 & .0 & .0 \\
\hline 3-Methylhexane & .0 & .8 & .6 & .3 & .0 & .0 \\
\hline 1,Trans-3-dimethylcyclopentane - & .0 & 1.2 & .8 & .4 & .0 & .0 \\
\hline 1,Trans-2-dimethylcyclopentane & .0 & 2.9 & 1.4 & .5 & .0 & .0 \\
\hline 3-Ethylpentane & .0 & .0 & .1 & .0 & .0 & .0 \\
\hline 2,2,4-Trimethylpentane & .0 & .0 & .0 & .0 & .0 & .0 \\
\hline n-Heptane & .0 & 1.4 & .6 & .4 & .0 & .0 \\
\hline 1,Cis-2-dimethylcyclopentane & .0 & .0 & .1 & .0 & .0 & .0 \\
\hline Methylcyclohexane & .0 & 15.1 & 8.8 & 3.5 & .0 & .0 \\
\hline \multicolumn{7}{|l|}{$\mathrm{C}_{1}$ to $\mathrm{C}_{\bar{\tau}}$ hydrocarbons, total: } \\
\hline $\mathrm{g} / \mathrm{g}$ sediment & $6 \times 10^{-9}$ & $7 \times 10^{-8}$ & $2 \times 10^{-6}$ & $1 \times 10^{-6}$ & $3 \times 10^{-8}$ & $4 \times 10^{-9}$ \\
\hline $\mathrm{g} / \mathrm{g}$ organic carbon & $1 \times 10^{-6}$ & $3 \times 10^{-6}$ & $8 \times 10^{-5}$ & $5 \times 10^{-5}$ & $5 \times 10^{-6}$ & $1 \times 10^{-6}$ \\
\hline
\end{tabular}

about $125^{\circ} \mathrm{F}$ (Evans and Staplin, 1970). Biogenically generated dry gas can form only at low temperatures (Claypool and Kaplan, 1974). Thus, the types of sediments in the COST No. B-2 well, although still somewhat immature with respect to liquid-hydrocarbon generation, may have been significant sources of dry and possibly wet gas.

The data also do not rule out generation of gas or oil in deeper, more thermally mature horizons, coupled with lateral and (or) vertical migration into favorable traps.

\section{GEOCHEMICAL MEASUREMENT AND INTERPRETATION-A COMPARISON}

The samples from the COST No. B-2 well were analyzed by a contract service-research laboratory (Geochem Laboratories) and by research laboratories of some participating major oil companies (including Superior, Amoco, and Phillips) prior to and in addition to the analyses done by the USGS. The reports of these private companies are on file for public inspection at the offices of the USGS, Washington,
D.C. It is interesting to compare the results and interpretations of different laboratories on samples from this well.

These analyses are compared with respect to the properties of the sedimentary organic matter they are intended to measure: richness, type (oil versus gas potential), and degree of maturity. These analyses are summarized for comparison in figures 17,18 , and 19 .

In figure 17, organic-carbon measurements done by Geochem Laboratories (1976) are compared with those done by the USGS. In general, the agreement on these analyses are excellent. Both sets of measurements, performed on independently selected samples, clearly show that the main intervals that contain rocks rich in organic carbon $(>1$ percent) are from about 3,000 to 6,000 feet and from about 10,000 to $14,-$ 000 feet. The USGS data show a sample containing 2.1 percent organic carbon at 8,220 to 8,240 feet, whereas all the samples analyzed by Geochem Laboratories in this same general interval are less than 1 percent. 


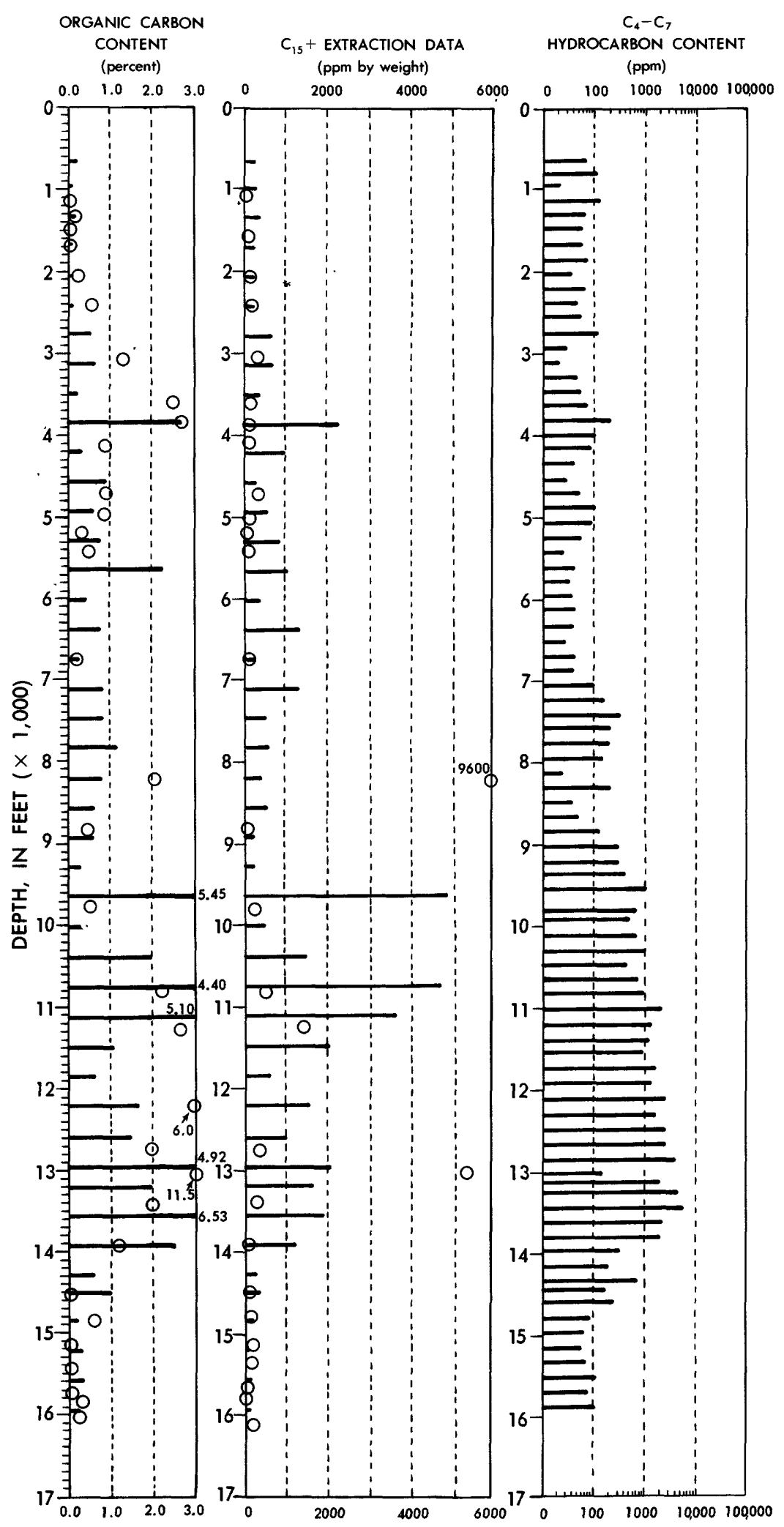

FIGURE 17.-Summary and comparison of analyses of richness of sediments in the COST No. B-2 well. Geochem Laboratories (1976) data are shown as bars, whereas USGS data are shown as circles. 
In figure 17, a comparison also is shown between the $\mathrm{C}_{15}+$ extraction data of Geochem Laboratories (1976) and organic compounds volatilized at less than $680^{\circ} \mathrm{F}\left(360^{\circ} \mathrm{C}\right)$ during thermal analysis by the USGS; both are expressed in parts per million by weight basis. These two different methods for estimating richness of organic matter are in fair agreement. The differences present are probably partly due to the effect of the different analytical tech.niques used, although both are inferred to measure the same constituents. The extraction technique depends on volatility to remove organic compounds from the rock. The thermal-analysis technique will detect light hydrocarbons that are lost in the isolation and gravimetric $\mathrm{C}_{15}+$-extractable determination. The solvent-extraction technique will remove very heavy (mostly asphaltic) compounds that are either nonvolatile or that are not transported from the furnace to the detector through lines maintained at $482^{\circ} \mathrm{F}\left(250^{\circ} \mathrm{C}\right)$. Where the $\mathrm{C}_{15}+$-extraction yields are significantly higher than the $86^{\circ}$ to $680^{\circ} \mathrm{F}\left(30^{\circ}-360^{\circ} \mathrm{C}\right)$ thermalanalysis yield, it is generally for samples that have especially high $\mathrm{NSO}+$ asphaltine content. The $86^{\circ}$ to $680^{\circ} \mathrm{F} \quad\left(30^{\circ}-360^{\circ} \mathrm{C}\right)$ thermal-analysis yields are higher than extraction yields for the interval (12,000-14,000 feet) where the highest $\mathrm{C}_{4}$ to $\mathrm{C}_{7}$ hydrocarbon contents were detected by Geochem Laboratories (1976) in a separate analysis, (fig. 17).

The extractable organic matter present at relatively high concentrations in the interval of about 9,000 to 14,000 feet was concluded by the USGS to be unlike petroleum, on the basis of gas-chromatographic analysis of the saturated hydrocarbons and by comparison of thermally extracted material with that generated by pyrolysis. Geochem Laboratories $(1976$, p. 2) had earlier arrived at the same conclusion, that is, that "... this interval has only generated methane gas and $\mathrm{C}_{2}-\mathrm{C}_{4}$ 'wet gas' hydrocarbons. This facies has not generated any petroleumrelated liquids and it is unlikely that any oil will be found in the immediate area of this well."

Four measurements that are sensitive to the type of organic matter in the COST No. B-2 well are summarized for comparison in figure 18. The first column shows a direct measurement of kerogen type and relative abundance, as determined in microscopic examination. The next three columns of figure 18 show the yield of pyrolytic hydrocarbons as a percentage of organic carbon, the atomic ratio of hydrogen to carbon in the kerogen, and the stable carbon isotopic composition of various fractions of the organic matter. These latter three techniques give an indirect indication of the type of organic matter and are also influenced by the state of diagenesis or degree of thermal maturation. The pyrolytic hydrocarbon yield as a percentage of organic carbon and the atomic hydrogen-carbon ratio of the kerogen are both related to the structure and liquid-hydrocarbongenerating potential of the kerogen. A fairly good correlation exists between these two measurements in the COST No. B-2 well, as shown. in columns two and three of figure 18.

The stable carbon-isotope ratio, ${ }^{13} \mathrm{C} /{ }^{12} \mathrm{C}$, is shown in figure 18 as parts per thousand (per mil) deviations from the ${ }^{13} \mathrm{C} /{ }^{12} \mathrm{C}$ ratio of the PDB marine carbonate standard. $\delta^{13} \mathrm{C}$ values are reported for kerogen (the fraction of the organic matter insoluble in benzene-methanol) for the total extract (the soluble fraction), and for the saturated or paraffin-napthene hydrocarbons that are separated from the total extract. The carbon-isotope ratio primarily reflects the nature of the source material or the environment in which the organic matter was generated by photosynthesis. In addition, the difference in $\delta^{13} \mathrm{C}$ between the kerogen and totalhydrocarbon extract may indicate the extent to which possible petroleumlike constituents have been generated from the solid organic matter.

In the COST No. B-2 well, the $\delta^{13} \mathrm{C}$ values of the kerogen appear to reflect the zonation seen on the basis of other organic geochemical characteristics, as described by Geochem Laboratories (1976). This fact probably reflects the abundant coaly material in Zone B. In general, a spread of about 2.5 per mil or more is found between the saturated hydrocarbon (or the extract) and the kerogen. This spread indicates that the materials probably have largely unrelated origins and that these lipid materials have not been generated from the kerogen by thermal diagenesis.

Figure 19 shows five different indicators of organic metamorphism or maturation-the numerical index (CPI) of the predominance of odd-numbered n-paraffin in the saturated hydrocarbons, the visual kerogen thermal-alteration index, vitrinite reflectance, temperature of maximum pyrolysis yield, and percent carbon 
Relative kerogen

type ond abundance (percent)

$\begin{array}{lll}0 & 50 \quad 100\end{array}$
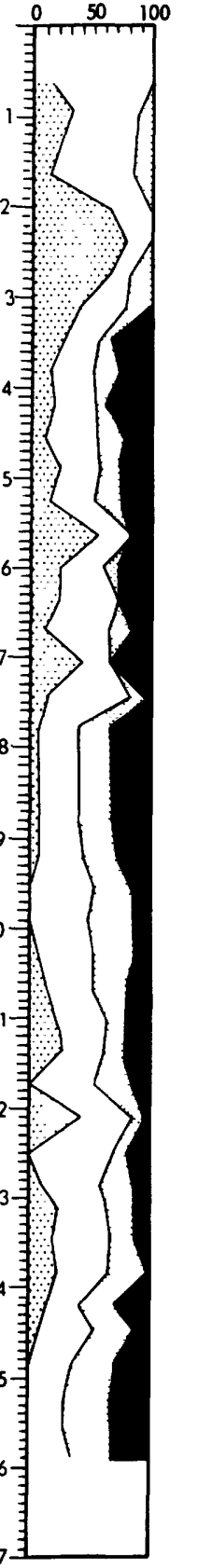

Amophous

Herboceous $\square$

Woody $\square$

Caaly
Pyrolitic

hydrocorbon/organic corbon

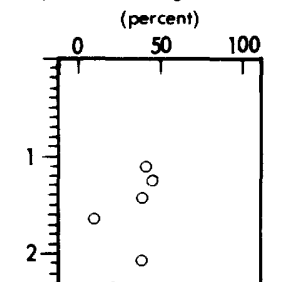

$\circ 0$

$\circ$
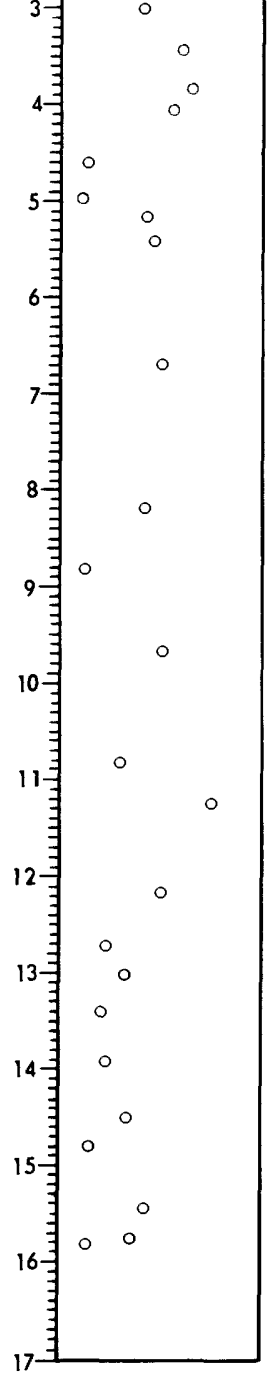

Atomic $\mathrm{H} / \mathrm{C}$ ratio

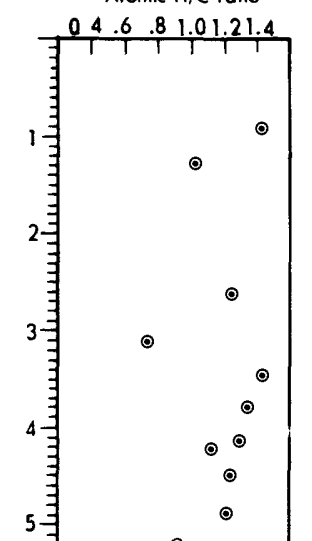

㖊寻

青

青

㖊 。

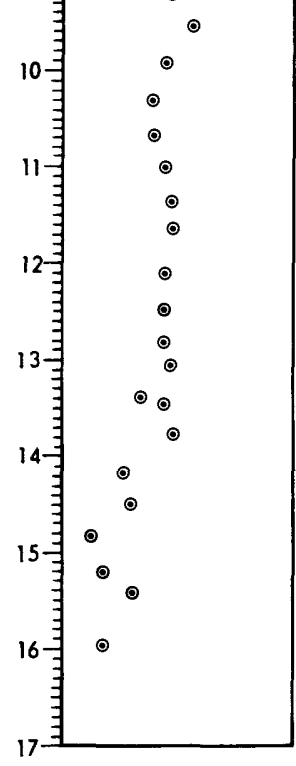

$\delta^{13} C_{\text {POB }}$ (permil)
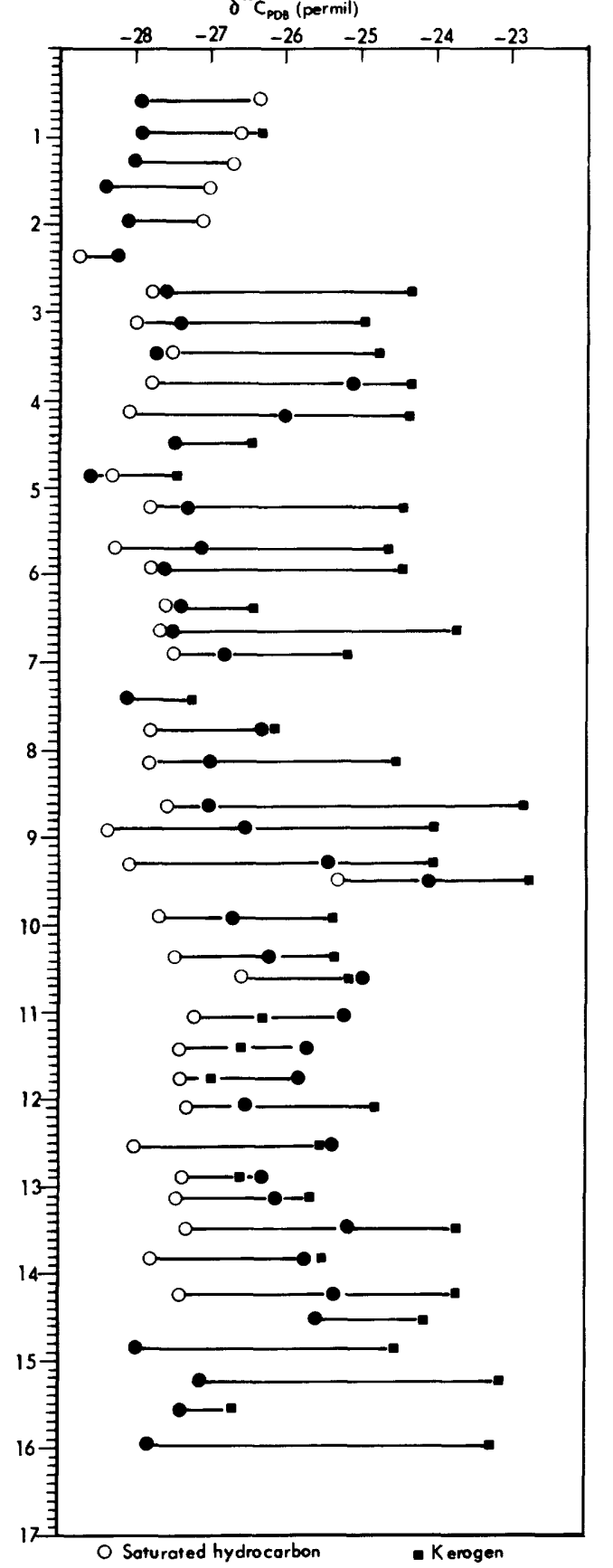

- Total extract

FIGURE 18.-Summary and comparison of analyses of type of organic matter in COST No. B-2 well samples. Data in the first column are from Geachem Laboratories (1976); second column, from this volume; third column, from Amoco Production Company (J. A. Momper, written commun., 1976); and the last column, from Phillips Petroleum Company (J. G. Erdman, written commun., 1976). 

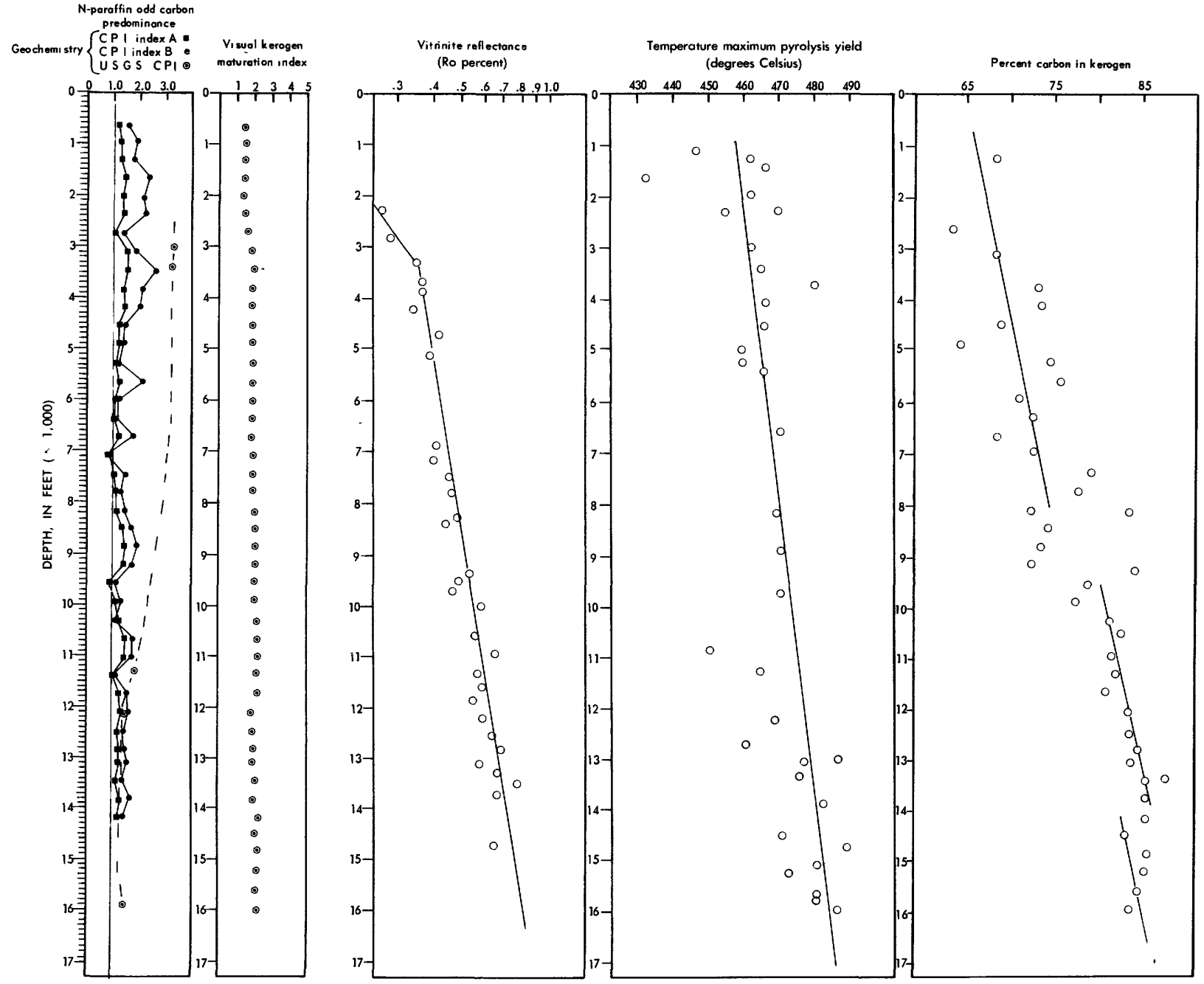

FIGURE 19.-Summary and comparison of analyses of maturity of organic matter in the COST No. B-2 well. Data in first column are from Geochem Laboratories (1976) and Claypool (this volume); in second column, from Geochem Laboratories (1976); in third column, from Superior Oil Co. (W. G. Dow, written commun., 1976) ; in fourth column, from Claypool (this volume); in fifth column, from Amoco Production Company (J. A. Momper, written commun., 1976).

in the kerogen. All these indicators show significant change as depth increases in the COST No. B-2 well. Although agreement is excellent among the different measurements, there are some apparent differences in interpretation of the significance of these measurements with respect to the generation of hydrocarbons. The interpretation of the vitrinite reflectance data by Superior Oil Company (W. G. Dow, written commun., 1976) stated that, "Although both oil and gas begin to be formed at maturities of about $0.45 R_{0}(6,800$ feet in the subject well), maximum generation and expulsion occur only below the top of the peak generation zones. On 
the basis of these criteria, effective oil source rocks (those which have both generated and expelled oil) could be present below 11,300 feet if organic matter capable of conversion to oil is present." The diagram accompanying this report shows "peak generation" at $R_{0}$ value of 0.6 percent, which takes place at 11,300 feet in this well.

The report on elemental analyses by Amoco Production Company (J. A. Momper, written commun., 1976), referring to the degree of carbonization of the kerogen, stated that, "The diagenesis level below 10,000 feet is equivalent to the peak stage for oil generation." This report also emphasized that the elemental data must be considered with the geochemical data of Geochem Laboratories (1976) and the vitrinite reflectance data of Superior Oil Company (W. G. Dow, written commun., 1976).

These reports of "peak generation" in the lower part of the section penetrated in the COST No. B-2 well seem to many observers to be in conflict with the interpretation by Geochem Laboratories (1976, p. ii) that, "These sediments $(9,500 \pm$ feet to $14,000 \pm$ feet $)$ have experienced an insufficient geothermal (timetemperature) history to have generated any petroleum-related liquids in the immediate vicinity of the COST No. B-2 well," or our interpretation that the organic matter in all samples analyzed appears to be immature in greater or lesser degree with respect to the degree of liquid-petroleum-hydrocarbon generation required for expulsion and economic occurrence of petroleum.

These apparent inconsistencies are due to the difficulty of inferring the extent of hydrocarbon-generating reactions from the nature of the solid organic matter. The decrease in CPI with depth shows that hydrocarbon generation began as depth increased in the COST No. B- 22 well. A greater change is shown for the USGS CPI data because the gas-chromatographic analysis was performed on SE-30-packed columns rather than on eutectic-salt-packed columns. The odd-carbon predominance is usually most pronounced in the $n-C_{29}$ region, and these compounds are partially oxidized during analysis on the eutectic column. This means that the CPI values given by Geochem Laboratories (1976) are minimum values and in particular do not reflect the degree of immaturity at shallow depths (less than 6,000 feet) in the COST No. B-2 well. Regardless of differences in the analytical technique, CPI decreases significantly between 3,000 feet and 12,000 feet. This undoubtedly reflects some degree of hydrocarbon generation. However, both the molecular composition of the saturated hydrocarbons in samples at 12,000 feet and the remaining hydrocarbon-generating potential shown by pyrolysis of samples at 13,000 feet indicate that the "principal phase of oil formation" has not yet taken place in this well.

The terms "peak generation" or "the top of the peak generation zone," as indicated by vitrinite reflectance and kerogen carbonization, are apparently used to designate upper depth limits, below which effective oil source rocks may occur and above which they cannot occur. Therefore, additional evidence is required before rocks at a specific depth in a well can be properly considered effective or possible oilsource rocks.

Another apparent contradiction lies in the interpretation of the geochemical data with regard to the gas- or wet-gas-source capabilities of the sediments penetrated in the COST No. B-2 well. Geochem Laboratories (1976), on the basis of measurement of $\mathrm{C}_{1}$ to $\mathrm{C}_{7}$ hydrocarbons, indicated that the interval from 9,500 to 14,000 feet has undergone good to excellent gas and wet-gas generation. However, the report by Superior Oil Company (W. G. Dow, written commun., 1976) concluded that "If only wet-gas source beds are present, they would be effective only below about 19,000 feet. . . ." The report by Amoco Production Company (J. A. Momper, written commun.,1976) implied a similar interpretation, in that a diagenesis level equivalent to peak generation for oil was considered early generation to early peak generation in sediments containing kerogen with potential only for wet-gas or gas generation. This interpretation is probably based on the fact that the main stage of gas production during coalification is after the stage of maximum liquid-hydrocarbon production (Teichmüller and Teichmüller, 1968). Sediments having an unusually high organic carbon content might be effective source rocks at a level of maturation less than the standard "peak generation" for either gas or oil. This may be the case for gas generation from the 9,500-to-14,000-foot interval of the COST No. B-2 well. 


\section{Color Alteration of Visible Organic Matter}

By E. I. Robbins

Color alteration of visible organic matter as a function of burial depth, especially when used in conjunction with vitrinite reflectance and organic geochemistry, can provide an indication of the probable maximum burial temperatures reached by the sediments and has strong bearing on the potential for hydrocarbon generation.

The sapropel fraction of organic matter is the amorphous breakdown product of living tissue. If the definition of Staplin and others (written commun., 1974) is used, this sapropel fraction is any amorphous matter present in aquatic sediments (in soil it is named humus) that has been created in relatively anoxic environments of deposition. Microscopically, it is seen as two forms: wispy, which was believed by Staplin and others (written commun., 1974) to form in higher energy environments; and fluffy, which accumulates in low-energy and more reducing environments.

The type of sapropel, as well as total organic: matter, is important from the viewpoint of the type of hydrocarbon that will be generated (McIver, 1967; Burrgess, 1974). The endpoint of the disseminated wispy sapropel and terrestrial organic matter is predominantly methane. The endpoint of the oil-shale type, the fluffy sapropel, can be liquid petroleum.

Most of the organic matter responds to temperature increases in the following manner: As volatile matter and oxygen are driven off, carbon is enriched, and the organic matter and itsi breakdown products become darker. On the basis of this response, a thermal-alteration scale has been prepared (Staplin, 1969; Evans and Staplin, 1970; Burgess, 1974). Because the petroleum-generating stage (the onset of browns) and the end of petroleum generation (black) are clearly recognizable, the technique is useful for determining the interval of probable liquidpetroleum generation.

The method of treatment is important as it determines the final interpretation of the organic matter (Bostick, 1971). Samples for the study of the sapropel fraction were composed of 100-foot composited intervals every 500 feet. Sample preparation included treatment in 10percent $\mathrm{HCl}$ (overnight) to eliminate carbonates and 50-percent HF (24 hours) to eliminate silicates.

\section{DATA}

Figures 6 and 20 are compilations of data collected on the degree of thermal alteration of the organic matter, relative sapropel abundance, and maturity. The terms for the degree of maturation in figure 20 have been taken from Evans and Staplin (1970) and refer to the maturity of the hydrocarbons. Immature sediments should contain yellow sapropel, mainly $\mathrm{C}_{1}$ gas, few gasoline-range hydrocarbons, and abundant heavy nonhydrocarbon compounds (mainly containing $\mathrm{N}, \mathrm{S}$, and $\mathrm{O}$ ). Mature facies should contain orange to brown sapropel, significant $\mathrm{C}_{2}$ to $\mathrm{C}_{4}$ gases, and abundant gasolinerange and heavy hydrocarbons.

Figure 20, shows an overall systematic increase in maturity of the sapropel as depth increases. However, from 5,510 to 6,090 feet, an anomalously sharp increase in maturity is indicated. From 14,510 to 15,600 feet there is a slight anomalous decrease in maturity.

Reworking, bacterial degradation, and oxidation are important processes that can be recognized and that must be differentiated from thermal alteration. Reworking is indicated by samples containing organic matter that has the whole spectrum of natural and alteration colors 


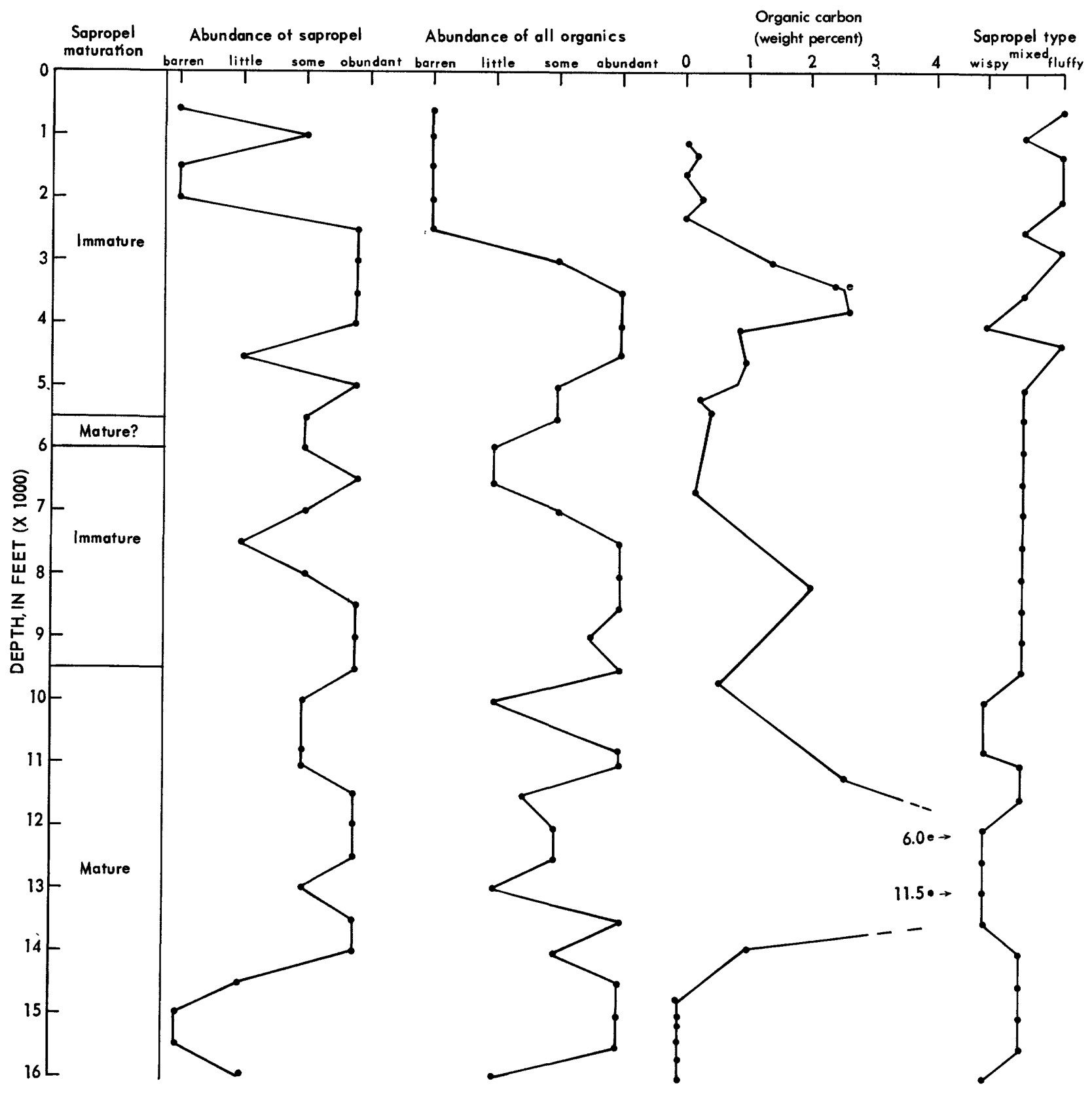

FIGURE 20.-Maturation, abundance, and types of sapropel, abundance of organic matter, and weight percent organic carbon as a function of depth. Weight percent organic carbon taken from report by Claypool and others (this volume).

-black, orange, brown, and yellow. Reworked organic grains are present in COST No. B-2 well samples from 1,600 to 1,630 feet, 6,420 to 6,430 feet, 6,320 to 6,330 feet, and 14,510 to 14,580 feet. Degraded organic matter, which suggests bacterial breakdown, is found in the following intervals (in feet): 4,290 to 4.320, 6,000 to $6,090,7,010$ to $7,100,7,500$ to 7,590 , 8,220 to $8,240,9,100$ to $9,130,(9,430$ to 9,440 ?), $(10,960$ to 10,990 ?), 11,260 to $11,290,11,560$ to
$11,590,11,860$ to $11,890,12,160$ to $12,190,12,-$ 460 to $12,490,13,010$ to $13,080,13,300$ to 13,330 , 15,120 to 15,130 , and 15,720 to 15,730 . Oxidized zones are common from 9,500 to 15,730 feet but also are found from 3,010 to 3,100 feet, 3,520 to 3,610 feet, 4,000 to 4,100 feet, and 4,500 to 4,620 feet.

The part of the stratigraphic section that has reached thermal maturity and that has the highest weight-percent organic carbon also 
contains dominantly wispy sapropel (fig. 20). This type generates mainly methane and not liquid petroleum. Thus, the potential of these lower intervals in the COST No. B-2 well is highest for gas generation, a conclusion substantiated by the organic geochemical data presented in this report.

\section{CONCLUSIONS}

The organic matter in the COST No. B-2 well shows an overall systematic increase in matu- rity with depth. In the depth range from 9,300 feet to the bottom of the well, temperatures apparently have been sufficient for generation of hydrocarbons. However, in the intervals with high weight-percent organic carbon, the sapropel is of the type more likely to yield natural gas than liquid petroleum. Deeper parts of the section, not penetrated by the COST No. B-2 well, are likely to be even more thermally mature and could have acted as gas or liquidhydrocarbon sources, depending on the type and amount of organic matter they contain. 


\title{
Geophysical Studies
}

\author{
By D. J. Taylor, R. E. Mattick, and K. C. Bayer
}

Figure 3, an interpretive profile of seismicreflection data from USGS Line 2, summarizes much of the geophysical data obtained in the Baltimore Canyon trough. Line 2, a 12-fold, common-depth-point (CDP), stacked section, was shot and processed by Digicon, Inc., in 1973. The location of the seismic line on the New Jersey shelf is shown in figure 1 ; the COST No. B-2 well and the onshore USGS Island Beach No. 1 well are projected into the line of section. Correlation of seismic reflectors with geologic units in the COST No. B-2 well is based on the work discussed earlier in this report together with velocity data derived from sonic logs recorded in the B-2 well (fig. 21). The correlation with the Island Beach well is based on the stratigraphic work of Perry and others (1975), pollen analyses of Doyle (written commun., 1974), and velocity analysis of the seismic-reflection data of Line 2.

\section{SEISMIC STRATIGRAPHY}

The age horizons determined from the COST No. B-2 well are illustrated in figure 3 to show their subsurface configuration. Previous determinations of the Neogene-Paleogene and Teritary-Cretaceous boundaries (Mattick and others, 1974) are in reasonable agreement with the revised interpretations made using COST No. B-2 well data.

The foreset bedding seen in the upper Tertiary section of seismic Line 2 has been interpreted by Garrison (1970) to represent a seaward progradation of deltaic sediments across the shelf during Tertiary time. As shown in figure 3, sediments from the base of the Pleistocene to the top of the Eocene thicken in a seaward direction from the Island Beach well, whereas Eocene and Paleocene beds remain relatively uniform in thickness across the seismic record section. According to Smith and others (1976), the lower Tertiary rocks produce strong seismic reflections having reflection coefficients +0.3 and -03 .

Upper Cretaceous strata are rather uniform in thickness from the USGS Island Beach No. 1 well to the edge of the Continental Shelf along Line 2. Again, however, thinning is evident over the intrusion. The COST No. B-2 well data have significantly raised the Upper Cretaceous-Lower Cretaceous boundary relative to earlier estimates by Mattick and others, (1974). Previously, Lower Cretaceous sediments were thought to begin at 2.4 seconds at shotpoint 1203 (where the COST No. B-2 well is projected into the section). This determination was based on extrapolation of onshore well data into the regional dip.

Lower Cretaceous rocks clearly thicken significantly from the Island Beach well to the northwest flank of the basement intrusion (shotpoint 900). Seaward of the intrusion, the Lower Cretaceous is again thought to be thick, although perhaps thinning seaward over possible reefs in Jurassic strata under the presentday Continental Slope. A seismic horizon slightly below the top of the Lower Cretaceous represents a prominent unconformity where at least 1,300 feet of sediment was removed by erosion. Jurassic strata apparently were not found in either the Island Beach well or the COST No. B-2 well; thus, correlation of the top of the Jurassic is difficult.

Near shotpoint 600 , strong reflectors appear on the seismic record section at a depth of 4.0 seconds. Interval velocities in the seismic time section between 4 and 5 seconds in this area may range from $16,000 \mathrm{ft} / \mathrm{sec}$ to more than $20,000 \mathrm{ft} / \mathrm{sec}$. These high interval velocities are 


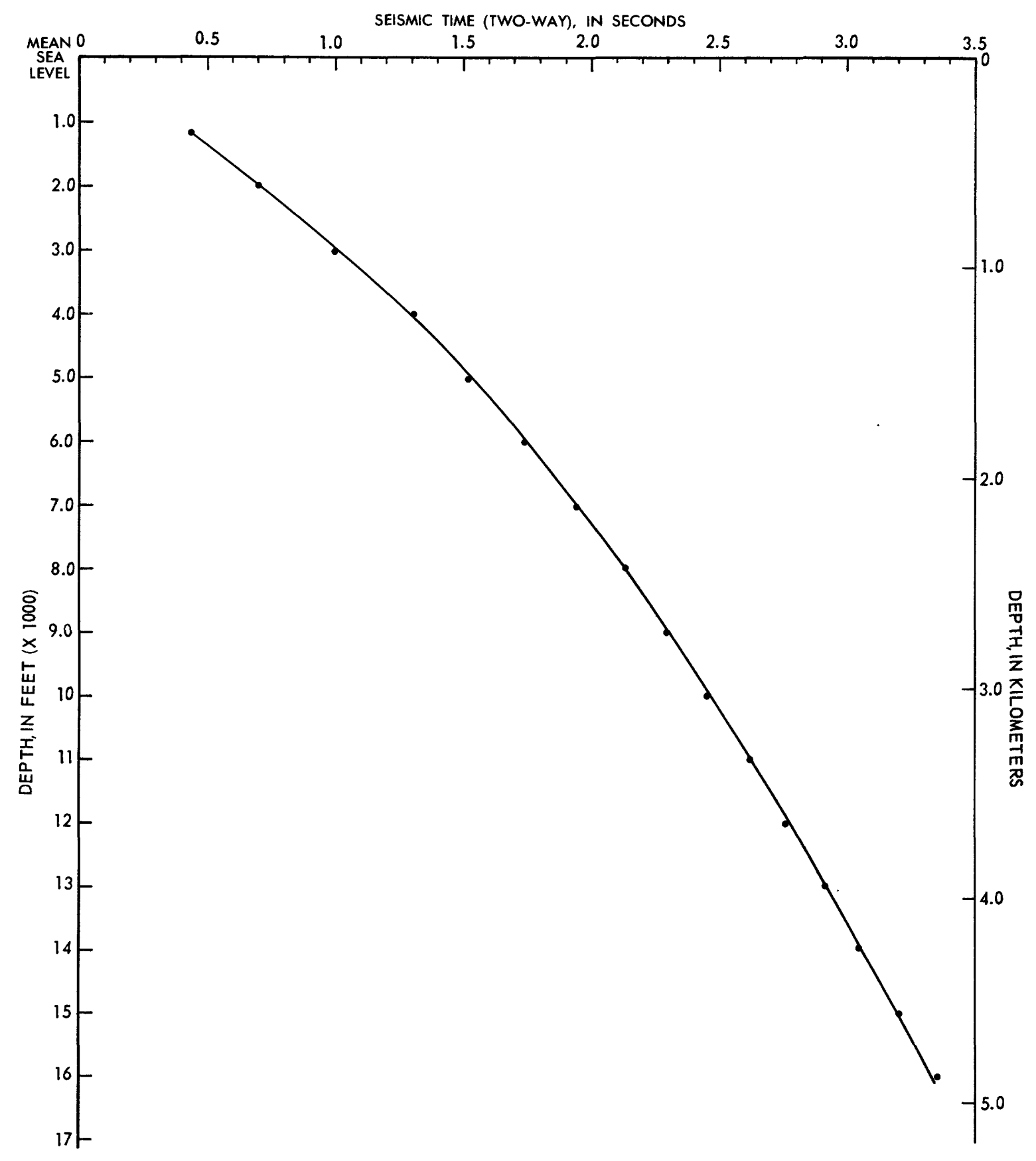

FigURe 21.-Seismic travel time (two-way) as a function of depth from the COST No. B-2 well sonic logs.

interpreted to represent a thick Jurassic and (or) Triassic sedimentary section.

Acoustic basement is thought to appear as a distinctive diffraction pattern at a depth of 1.65 seconds on the northwest end of Line 2, which correlates with crystalline basement rocks in the Island Beach well. According to Mattick and others (1975) and Schlee and others (1976), this horizon deepens to more than 45,000 feet and appears at approximately
7 seconds (reflection time) in the vicinity of shotpoint 800 . Near shotpoint 500, the basement horizon is underlain by a series of more steeply dipping reflectors. These have been interpreted by Mattick and others (1976) as representing Triassic or Paleozoic marine sediments. According to Schlee and others (1976), these reflectors may indicate layering within metasedimentary rocks thought to underlie the Baltimore Canyon trough. 
Between shotpoints 900 and 1,100 , sedimentary rocks, which are otherwise gently dipping, are warped upward. In this area, Taylor and others (1968) have mapped a 500-gamma magnetic high interpreted as a basement intrusion that may be in a zone of weakness near the intersection of two fault systems, one parallel to the Continental Shelf and a second oblique to the shelf edge. Although depth to basement in the vicinity of the intrusion cannot be determined from the seismic record section, John C. Behrendt (written commun., 1976), has indicated that the depth to magnetic basement at shotpoint 1,000 is between 12,000 and 13,000 feet.

Another smaller piercement structure is seen in the vicinity of shotpoint 725 . As reflectors seem to continue through the structure, we assume it to be out of the plane of section.

\section{LITHOLOGIC INFORMATION}

The sedimentary section in the Baltimore Canyon trough, previously inferred from seismic response and now confirmed by COST No. B-2 well information is composed primarily of sand and shale. The relative percentages of each lithology and their degree of diagenetic alteration have been unknown until now.

As evident from the COST No. B-2 well, the upper Tertiary, from the upper Pliocene to about the middle Eocene, consists mainly of sandstone, shale, and mudstone that have been compacted to varying degrees. Seismic evidence suggests that this is true throughout the basin, the degree of compaction increasing below the lower Miocene. Relatively low interval velocities, computed along seismic-reflection Line 2 indicate that upper Tertiary rocks may remain relatively unconsolidated across the entire shelf. From middle Eocene to Late Cretaceous time, COST No. B-2 well information reveals a relatively dense, calcareous shale and sandstone sequence. These calcareous units are apparently limited to the seaward part of the basin, as indicated by a decrease in velocity in this interval as one moves toward shore. Velocity in this interval increases significantly over the basement intrusion perhaps because of increased compaction over this feature or higher sand content in the sediments.

In the Upper Cretaceous strata, the seismic signals and the velocity data suggest a pre- dominantly sandstone and shale section. COST No. B-2 well data substantiate this and show that some limestone beds are also present in this interval. Interval velocities decrease in a shoreward direction, suggesting a decrease in the carbonate content in nearshore areas.

The seismic-reflection signatures and velocity information suggest that the lithologies found in the Lower Cretaceous section in the B-2 well (mainly sandstone and shale) extend throughout much of the basin. Increases in velocity in the basal Lower Cretaceous sediments seaward of the COST No. B-2 well suggest an increase in the amount of interbedded limestone. Velocities in the Lower Cretaceous interval over the intrusion (and above the unconformtiy) do not indicate a strong increase in compaction.

Although Jurassic strata apparently were not penetrated in the COST No. B-2 well, a significant thickness of Jurassic sediments is thought to exist in the deeper parts of the basin. Seismic evidence suggests a more calcareous lithology for the Jurassic(?) section than for the overlying section. According to Maher (1971), a 100-foot carbonate sequence was found in the Esso Hatteras Light No. 1 well (North Carolina) at the top of the Jurassic or base of the Cretaceous. The interval contains oolitic limestone, porous granular dolomite, and anhydrite. Dip rates projected from onshore well data suggest that Jurassic beds thicken in an offshore direction. On the basis of a refraction survey shot by Hersey and others (1959), Gibson (1970) suggested that a thick layer of rocks, which appears to onlap crystalline base. ment offshore from the Hatteras well, represents a seaward extension of the Jurassic limestone, dolomite, and anhydrite.

Carbonate rocks of Jurassic age (Abenaki Formation) have also been reported beneath the Scotian Shelf off Canada (McIver, 1972). In addition, information from DSDP hole 105 indicates that east of the Baltimore Canyon trough, near the base of the Continental Rise, about 2,000 feet of Neocomian, Tithonian, Kimmeridgian, and Oxfordian limestone overlies oceanic basement (Hollister and others, 1972).

On the basis of a velocity inversion below 40,000 feet, Mattick and others (1976) have speculated that Lower Jurassic evaporites may overlie basement rocks in the Baltimore Canyon trough area. Other evidence of evaporites on the Atlantic margin comes from well data on 


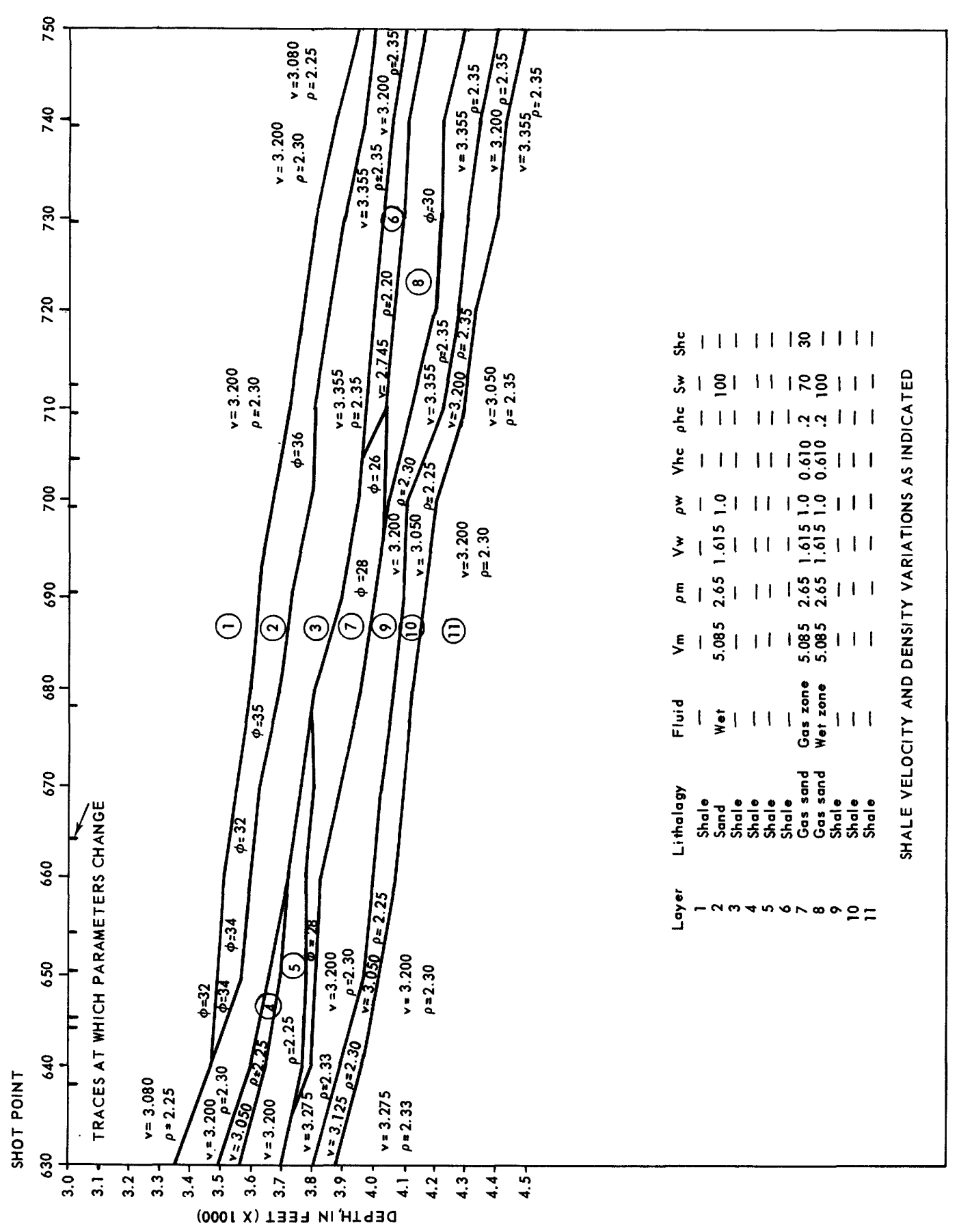

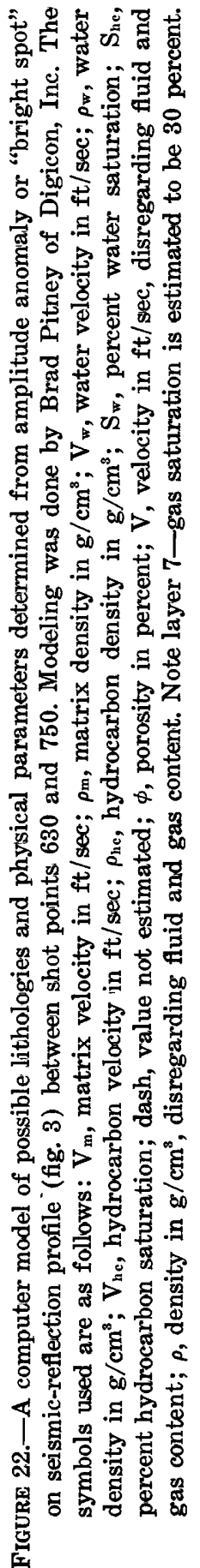


the Canadian shelf. The Shell Argo F-38 well, on the south flank of the Orpheus basin north of Nova Scotia, drilled through approximately 2,600 feet of relatively pure halite. In addition, on the basis of seismic data, Emery and others (1970) have suggested that diapiric salt structures are present along the Continental Slope and Rise off Nova Scotia. Similar structures may exist in the Baltimore Canyon trough area.

Jurassic strata are not thought to be present over the intrusion along Line 2 ; whether or not Jurassic is present seaward of this feature is speculative. If present, its lithology is inferred to be mainly carbonate rocks containing little salt.

\section{AMPLITUDE ANOMALIES}

True amplitude processing of Line 2 revealed an amplitude anomaly between shotpoints 640 and 760. Depth to the anomaly is 0.75 to 0.80 seconds, corresponding roughly to 3,700 to 3,800 feet. Projection from the COST No. B-2 well and from the Island Beach No. 1 well indicates that these sediments are of late Oligocene age and are composed predominantly of shale and claystone containing a few beds of coarse-grained sandstone.

Seismic modeling or "bright-spot" analyses indicates that the amplitude anomaly could be caused by a gas sand trapped between shale beds. As modeled (fig. 22), the sand is in a foreset sequence; updip migration of gas is blocked by an impermeable shale barrier. A water drive is indicated on the low side of the sand body. Maximum reservoir-sand thickness is calculated to be about 100 feet near shotpoint 680. Porosity in the gas sand was modeled as ranging from 26 percent to 28 percent. Saturation of water and gas were calculated as 70 percent and 30 percent, respectively. 


\section{Conclusions}

1. The COST No. B-2 well penetrated nearly 16,000 feet of sediment in the Baltimore Canyon trough of the AOCS. The age of the sediments (determined through the examination of Foraminifera, calcareous nannofossils, and palynomorphs) is Cenozoic down to about 5,000 feet. From 5,000 to 8,100 feet, the sediments are Late Cretaceous in age, and from 8100 feet to the base of the well, they are Early Cretaceous. Although no positive indications of Jurassic sediments were found in this well, a Jurassic age cannot be ruled out for the basal 1,000 to 2,000 feet of section.

2. Early Cretaceous depositional environments in the B-2 area were apparently primarily nonmarine; occasional shallow marine incursions took place. The Late Cretaceous environments were generally shallow marine, with the exception of a nonmarine interval during the Coniacian and Santonian. During the Eocene, water depths were similar to those found on present continental slopes; later Tertiary sediments were deposited in outer- to innershelf environments.

3. The dominant lithologies found were sandstone and shale and minor limestone, coal, and lignite. Sand-shale ratios vary with depth but generally are 25 to 65 percent.

4. Porosities and permeabilities in the sandstone and shale section decrease rapidly as depth increases, so that below 12,000 feet, most sandstones have less than 15 percent porosity and 1 millidarcy permeability.

5. Petrographic analysis indicates that most of the sandstone is feldspathic. Much of the porosity loss seen at depth is due to breakdown of feldspar and the generation of authigenic clay and silica cement. Calcite cement is also very important, especially in zones having primary calcareous components.

6. The present geothermal gradient in the COST No. B-2 well is $1.3^{\circ} \mathrm{F} / 100$ feet.

7. Organic geochemistry and color alteration of visible organic matter, in conjunction with vitrinite reflectance, indicate either immaturity or low thermal maturity for most of the section down to at least 12,000 feet. Furthermore, although many units have very high organic carbon contents (as much as 12 percent), most of the sediments in the most thermally mature zones have terrestrially derived organic matter.

8. The combination of all the above factors indicates a relatively low potential for liquid-hydrocarbon generation and a relatively high potential for natural-gas generation. Deeper parts of the section (below 16,000 feet) or other parts of the Baltimore Canyon trough may have the potential to generate oil or gas, depending on the amount and character of their contained organic matter. 


\section{References Cited}

Baker, D. R., and Claypool, G. E., 1970, Effects of incipient metamorphism on organic matter in mudrock: Am. Assoc. Petroleum Geologists Bull., v. 54, no. B, p. 456-468.

Bartenstein, Helmut, and Teichmüller, Rolf, 1974, Inkohlungsuntersuchungen, ein Schlüssel zur Prospektierung von paläozoischen Kohlenwasserstcff-Lagerstätten?: Fortschr. Geologie Rheinland u. Westfalen, v. 24, p. 129-160.

Berggren, W. A., 1972, A Cenozoic time scale-Some implications for regional geology and paleobiogeography: Lethaia, v. 5, no. 2, p. 195-215.

Blow, W. H., 1969, Late Middle Eocene to Recent planktonic foraminiferal biostratigraphy, in Internat. Conf. on Planktonic Microfossils 1st, Geneva, Switzerland, 1967, Proc., v. 1: Leiden, Netherlands, E. J. Brill, p. 199-422.

Bostick, N. H., 1971, Thermal alteration of clastic organic particles as an indicator of contact and burial metamorphism in sedimentary rocks: Geascience and Man, v. 3, p. 83-93.

Bott, M. H. P., 1971, Evolution of young continental margins and formation of shelf basins: Tectonophysies, v. 11, no. 5, p. 319-327.

Bramlette, M. N., and Wilcoxon; J. A., 1967, Middle Textiary calcareous nannoplankton of the Cipero section, Trinidad, W. I.: Tulane Studies Geology, v. 5, no. 3, p. 93-131.

Brenner, G. J., 1963, The spores and pollen of the Potomac Group of Maryland: Maryland Dept. Geology, Mines, and Water Resources Bull. 27, 215 p.

Brooks, J. D., and Smith, J. W., 1967, The diagenesis of plant lipids during the formation of coal, petroluem and natural gas, I. Changes in n-parafins: Geochim. et Cosmochim. Acta, v. 31, p. 2389-2397.

Bukry, David, 1973, Low-latitude coccolith biostratigraphic zonation, in Edgar, N. T., Saunders, J. B., and others, eds., Initial reports of the Deep Sea Drilling Project, v. 15: Washington, D.C., U.S. Govt. Printing Office, p. 685-703.

1975, Coccolith and silicoflagellate stratigraphy, northwestern Pacific Ocean, Deep Sea Drilling Project, Leg 32, in Larson, R. L., Moberly, R., and others, eds., Initial reports of the Deep Sea Drilling Project, v. 32: Washington, D.C., U.S. Govt. Printing Office, p. 677-692.

Burgess, J. D., 1974, Microscopic examination of kerogen (dispersed organic matter) in petroleum exploration, in Dutcher, R. E., ed., Carbonaceous materials as indicators of metamorphism: Geol. Soc. America Spec. Paper 153, p. 19-30.
Bybell, L. M., 1975, Middle Eocene calcareous nannofossils at Little Stave Creek, Alabama: Tulane Studies Geology and Paleontology, v. 11, no. 4, p. 177-252.

Claypool, G. E., and Kaplan, I. R., 1974, The origin and distribution of methane in marine sediments, in I. R. Kaplan, ed., Natural gases in marine sediments: Marine Sci., v. 3, p. 99-139.

Claypool, G. E., and Reed, P. R., 1976, Thermal-analysis technique for source-rock evaluation-Quantitative estimate of organic richness and effects of lithologic variation: Am. Assoc. Petroleum Geologists Bull., v. 60, no. 4 , p. 608-611.

Core Laboratories, Inc., 1976, Core studies, C.O.S.T. Atlantic well B-2, Baltimore Canyon: Dallas, Tex., $168 \mathrm{p}$.

Doyle, J. A., and Robbins, E. I., in presis, Angiosperm pollen zonation of the continental Cretaceous of the Atlantic Coastal Plain and its application to deep wells in the Salisbury Embayment: Palynology, v. 1.

Drake, C. L., Ewing, W. M., and Sutton, G. H., 1959, Continental margins and geosynclines-The east coast of North America north of Cape Hatteras, in Ahrens, L. H., and others, eds., Physics and chemistry of the Earth: New York, Pergamon Press, v. 3, p. 110-199.

Emery, K. O., Uchupi, Elazar, Phillips, J. D., Bowin, C. O., Bunce, E. T., and Knott, S. T., 1970, Continental Rise off eastern North America: Am. Assoc. Petroleum Geologists Bull., v. 54, no. 1, p. 44-108.

Evans, C. R., and Staplin, F. L., 1970, Regional facies of organic metamorphism: Internat. Geochem. Explor. Symposium, 3d, Proc., p. 517-520.

Falvey, D. A., 1974, The development of continental margins in plate tectonic theory: APE A Jour., v. 14, p. 95-106.

Folk, R. L., 1968, Petrology of sedimentary rocks: Austin, Texas, Hemphill's, $170 \mathrm{p}$.

Garrison, L. E., 1970, Development of Continental Shelf south of New England: Am. Assoc. Petroleum Geologists Bull., v. 54, no. 1, p. 109-124.

Geochem Laboratories, Inc., 1976, Hydrocarbion source facies analysis, COST Atlantic B-2 well, Baltimore Canyon, offshore Eastern United States: Houston, Tex., 12 p.

Gibson, T. G., 1970, Late Mesozoic-Cenozoic tectonic aspects of the Atlantic coastal margin: Geol. Soc. America Bull., v. 81, no. 6, p. 1813-1822.

Habib, Daniel, 1976, Cretaceous dinoflagellate and sporomorph zonations at D.S.D.P. site 391C, and its correlation in the North Atlantic [abs.]: Am. Assoc. Stratig. Palynologists and Comm. Internat. Micro- 
flore Paléozoique, Joint Mtg., Halifax, Nova Scotia, Oct. 12-16, 1976, Abs. (with Program), p. 10.

in press, Comparison of Lower and Middle Cretaceous palynostratigraphic zonations in the Western North Atlantic, in Symposium on stratigraphic micropaleontology of Atlantic basins and borderlands, Proc.: New York, Elsevier Pub. Co.

Harper, M. L., 1971, Approximate geothermal gradients in the North Sea basin: Nature, v. 230, no. S291, p. 235-236.

Harris, T. M., 1935, The fassil flora of Scoresby Sound, East Greenland, Pt. 4: Ginkgoales, Coniferales, Lycopodiales, and isolated fructifications: Medd. Grønland, v. 112, no. 1, 176 p.

Harrison, W. E., 1976, Graphitization of sedimentary organic matter-A potentially useful method for assessing paleotemperatures [abs.]: Geol. Soc. America Abs. with Programs, v. 8, no. 2, p. 191192.

Hersey, J. B., Bunce, E. T., Wyrick, R. F., and Dietz, F. T., 1959, Geophysical investigation of the continental margin between Cape Henry, Virginia, and Jacksonville, Florida: Geol. Soc. America Bull., v. 70 , no. 4 , p. $437-466$.

Hollister, C. D., Ewing, J. I., Habib, D, Hathaway, J. C., Lancelot, Y., Luterbacher, H., Paulus, F. J., Poag, C. W., Wilcoxon, J. A., and Worstell, P., 1972, Site 105-Lower Continental Rise hills, in Kaneps, A. G., Sci. ed., Initial reports of the Deep Sea Drilling Project, v. 11: Washington, D. C., U.S. Govt. Printing Office, p. 219-312. [Joint Oceanographic Institutions for Deep Earth Sampling project (JOIDES). Prepared for National Science Foundation (NSF) Natl. Ocean Sediment Coring Program.]

Hood, A., and Castaño, J. R., 1974, Organic metamorphism-Its relationship to petroleum generation and application to studies of authigenic minerals: United Nations ESCAP, CCOP Tech. Bull., v. 8, p. 85-118.

Hood, A., Gutjahr, C. C. M., and Heacock, R. L., 1975, Organic metamorphism and the generation of petroleum: Am. Assoc. Petroleum Geologists Bull., v. 59, no. 6, p. 986-996, 7 figs. Jam L., Pedro, Dickey, P. A., and Tryggvason, Eysteinn, 1969, Subsurface temperature in South Louisiana: Am. Assoc. Petroleum Geologists Bull., v. 53, no. 10, pt. 1, p. 2141-2149.

Jam L., Pedro, Dickey, P.A., Tryggvason, Eysteinn, 1969, Subsurface temperature in south Louisiana: Am. Assoc. Petroleum Geologists, v. 53, no. 10, pt. 1, p. 2141-2149.

Krutzsch, Wilfried, 1957, Sporen- und Pollengruppen aus der Oberkreide und dem Tertiär Mitteleuropas und ihre stratigraphische Verteilung: Zeitschr. Angew. Geologie, v. 3, no. 11-12, p. 509-548.

Maher, J. C., 1971, Geologic framework and petroleum potential of the Atlantic Coastal Plain and Continental Shelf: U.S. Geol. Survey Prof. Paper 659, $98 \mathrm{p}$.

Mattick, R. E., Folger, D. N., Foley, N. T., Dolton, G. L., Bayer, K. C., 1976, Summary report of the sediments, structural framework, petroleum potential, environmental conditions, and operational considerations of the United States Mid-Atlantic Continental Shelf: U.S. Geol. Survey Open-file Rept. 76532, 26 p.
Mattick, R. E., Foote, R. Q., Weaver, N. L., and Grim, M. S., 1974, Structural framework of United States Atlantic Outer Continental Shelf north of Cape Hatteras: Am. Assoc. Petroleum Geologists Bull., v. 58, no. 6, pt. 2, p. 1179-1190.

[Mattick, R. E., Perry, W. J., Jr., Robbins, E. I., Rhodehamel, E. C., Weed, E. G. A., Taylor, D. J., Krivoy, H. L., Bayer, K. C., Lees, J. A., and Clifford, C. P.], 1975, Sediments, structural framework, petroleum potential, environmental conditions, and operational considerations of the Mid-Atlantic Area: U.S. Geol. Survey Open-file Rept. 75-61, 143 p.

McIver, N. L., 1972, Cenozoic and Mesozoic stratigraphy of the Nova Scotia Shelf: Canadian Jour. Earth Sci., v. 9 , no. 1 , p. 54-70.

McIver, R. D., 1967, Composition of kerogen-Clue to its role in the origin of petroleum, in Origin of oil, geology and gaophysics-World Petroleum Cong., 7th, Mexico, 1967, Proc., v. 2 : London, Elsevier Pub. Co., p. 25-36.

Minard, J. P., Perry, W. J. Jr., Weed, E. G. A., Rhodehamel, E. C., Robbins, E. I., and Mixon, R. B., 1974, Preliminary report on geology along Atlantic continental margin of northeastern United States: Am. Assoc. Petroleum Geologists Bull., v. 58, no. 6, pt. 2, p. 1169-1178.

Murray, Nesbitt, 1939, The microflora of the upper and lower Estuarine Series of the East Midlands: Geol. Mag., v. 76 , no. 11 , p. $478-489$.

Norris, Geoffrey, 1970, Palynology of the Jurassic-Cretaceous boundary in southern England: Geoscience and Man, v. 1, p. 57-65.

Norris, Geoffrey, Jarzen, D. M., and Awai-Thorne, B. V., 1975, Evolution of the Cretaceous terrestrial palynoflora in western Canada: Geol. Assoc. Canada Spec. Paper 13, p. 333-364.

Nwachukwu, S. O., 1976, Approximate geothermal gradients in Niger Delta sedimentary basin: Am. Assoc. Petroleum Geologists Bull., v. 610, no. 7, p. 1073-1077.

Perry, W. J., Jr., Minard, J. P., Weed, E. G. A., Robbins, E. I., and Rhodehamel, E. C., 1975, Stratigraphy of Atlantic coastal margin of United States north of Cape Hatteras.-Brief survey: Am. Assoc. Petroleum Geologists Bull., v. 59, no. 9, p. 1529-1548.

Pocock, S. A. J., 1962, Microfloral analysis and age determination of strata at the Jurassic-Cretaceous boundary in the Western Canada Plains: Palaeontographica, v. 111, Abt. B, pts. 1-3, p. 1-95.

Proto Decima, Franca, Roth, P. H., and Todesco, L., 1975, Nannoplancton calcareo del Paleocene e dell'Eocene della szzione de Possagno: Schweizer. Paläont. Abh., v. 97 . p. $35-55,149-161$.

Pusey, W. C., III, 1973, the ESR-kerogen method-How to evaluate potential gas and oil source rocks: World Oil, v. 176, no. 5, p. 71-75.

Robbins, E. I., Perry, W. J., Jr., and Doyle, J. A., 1975, Palynological and stratigraphic investigations of four deep wells in the Salisbury embayment of the Atlantic Coastal Plain: U.S. Geol. Survey Open-file Rept. 75-307, $120 \mathrm{p}$.

Robbins, E. I., and Rhodehamel, E. C., 1976, Geothermal gradients help predict petroleum potential of Scotian Shelf: Oil and Gas Jour., v. 74, no. 9, p. 143-145.

Schlee, John, Behrendt, J. C., Grow, J. A., Robb, J. M., Mattick, R. E., Taylor, P. T., and Lawson, B A., 
1976, Regional geologic framework off Northeastern United States: Am. Assoc. Petroleum Geologists Bull., v. 60, no. 6, p. 926-951.

Sheridan, R. E., 1974, Preliminary report on a geophysical study of a dome structure on the Atlantic Outer Continental Shelf east of Delaware [abs]: Geol. Soc. America Abs. with Programs, v. 6, no. 7, p. 952.

Sirkin, L. A., 1974, Palynology and stratigraphy of Cretaceous strata in Long Island, New York, and Block Island, Rhode Island: U.S. Geol. Survey Jour. Research, v. 2, no. 4, p. 431-440.

Sleep, N. H., 1971, Thermal effects of the formation of Atlantic continental margins by continental breakup: Royal Astron. Soc. Geophys. Jour., v. 24, no. 4, p. 325-350.

Smith, M. A., Amato, R. V., Furbush, M. A., Pert, D. M., Nelson, M. E., Hendrix, J. S., Tamm, L. C., Wood, Jr., G., and Shaw, D. R., 1976, Geological and operational summary, COST No. B-2 well, Baltimore Canyon trough area, Mid-Atlantic OCS: U.S. Geol. Survey, Open-file Rept. 76-774, 79 p.

Staplin, F. L., 1969, Sedimentary organic matter, organic metamorphism, and oil and gas occurrence: Bull. Canadian Petroleum Geology, v. 17, no. 1, p. 47-66.

Taylor, P. T., Zietz, Isidore, and Dennis, L. S., 1968, Geologic implications of aeromagnetic data for the eastern continental margin of the United States: Geophysics, v. 33, no. 5, p. 755-800.

Teichmüller, Marlies, and Teichmüller, Rolf, 1968, Geological aspects of coal metamorphism, in Murchison, Duncan, and Westoll, T. S., eds., Coal and Coal-bearing strata: Edinburgh, Oliver and Boyd, p. 233-267.
Tissot, B. P., Durand, B., Espitalie, J., and Combaz, A., 1974, Influence of nature and diagenesis of organic matter in formation of petroleum: Am. Assoc. Petroleum Geologists Bull., v. 58, no. 3, p. 499-506.

Van Hinte, J. E., 1976, A Cretaceous time scale: Am. Assoc. Petroleum Geologists Bull., v. 60, no. 4, p. 498-516.

Vassoyevich, N. B., Korchagina, Yu. I., Lopatin, N. V., and Chernyshev, V. V., 1970, Glavnaya faza nefteobrazovaniya [Principal phase of oil formation]: Moskov. Univ. Vestnik, Ser. 4, Geologii, v. 24, no. 6, p. 3-27; English translation: Internat. Geology Rev., v. 12, no. 11, p. 1276-1296.

West, Jim, 1976. U.S. operators plunge big in Baltimore Canyon sale: Oil and Gas Jour., v. 74, no. 34, p. 4549.

Williams, G. L., 1974, Dinoflagellate and spore stratigraphy of the Mesozoic-Cenozoic, offshore Eastern Canada: Canada Geol. Survey Paper 74-30, v. 2, p. 107-161.

Wolfe, J. A., 1976, Stratigraphic distribution of some pollen types from the Campanian and lower Maestrichtian rocks (Upper Cretaceous) of the Middle Atlantic States: U.S. Grol. Survey Prof. Paper 977, $18 \mathrm{p}$.

Wolfe, J. A., and Pakiser, H. M., 1971, Stratigraphic interpretations of some Cretaceous microfossil floras of the Middle Atlantic States, in Geological Survey Research 1971: U.S. Geol. Survey Prof. Paper 750B, p. B35-B47. 